\title{
EVIDENTIARY BARRIERS TO CONVICTION AND TWO MODELS OF CRIMINAL PROCEDURE: A COMPARATIVE STUDY
}

\author{
MmJan DaMašKa†
}

\section{TABLE OF CONTENTS}

InTRODUCTION ............................ 507

PART I. COMPARISON OF EVIDENTIARY BarrIERS to ConvicTION ...................... 513

A. Activities Preliminary to Proof-taking ....... 513

1. Admissibility Rules Designed to Improve Factfinding Accuracy ............. 514

2. Admissibility Rules Governed by Considerations Extraneous to Truth-finding ....... 521

3. An Overview .................. 525

B. Presentation of Evidence ............. 525

1. The Defendant as an Evidentiary Source at Trial ....................... 526

2. Operation of Corroboration Rules ....... 530

3. Counterbalancing Factors ............ 531

a. Prima facie Presumptions of Guilt ..... 531

b. Disclosure of Evidence Compared ...... 533

C. Weighing of Evidence ............... 536

1. Different Rules Governing Voting ...... 536

2. Professional and Lay Propensities to Convict 538

3. Trial Structure and Evidentiary Needs .... 544

4. The Mechanics of the Persuasive Burden .. 546

a. Guilt Presumptions Affecting the Burden of Persuasion ............... 546

b. Affirmative Defenses and the Burden of Proof ....................... 548

D. Summary and Perspective ........... 550

1. The Interrelationship of Fact-finding Styles .. $\quad 550$

$\dagger$ Professor of Law, University of Pennsylvania. Formerly Professor of Law, University of Zagreb (Yugoslavia). Dr. Jur. 1960, University of Ljubljana (Yugoslavia).

The author gratefully acknowledges the help of Professor Bruce Ackerman who read and commented on an earlier draft of Part I of this Article and suggested the writing of Part II. While he has thus contributed to the present shape of this Article, he is absolved of any responsibility for the views expressed within its contours. The author's warm thanks go to Mrs. Elaine Garfinkel for encouragement in working on Part II. 
2. Some Consequences of Uneven Prosecutorial Burdens ........................

Part II. Barriers to Conviction and Two Rtval Proce-

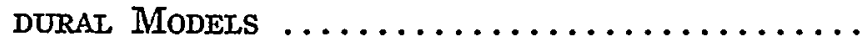

A. Essential Characteristics of Adversary and Non-

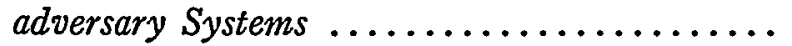

1. Continental Scholarship ............ 555

a. The Historical Approach ........... 555

b. Two Narrow Technical Views ......... 560

c. Procedural Models and the Analytic Approach ..................... 561

d. Procedural Types in Marxist Literature 565

2. American Opinions and Scholarly Writing .. 569

a. The Manichaean Dichotomy ......... 569

b. A Narrow View .................. 570

c. Rival Models of Procedure .......... 571

3. Choice of the Proper Dichotomy ......... 577

B. Rival Procedural Systems and Commitment to the Discovery of Truth ............. 578

1. Pursuit of Truth and Procedural Structure .. 580

2. The Search for Truth and Ideological Preconceptions ...................... 583

3. Commitment to Truth Examined in the Light of Historical Considerations ........... 584

4. A Final Caveat ................ 587

\section{INTRODUCTION}

Comparative research of criminal justice systems is still in its infancy. It is not surprising, then, that when questions are asked transcending the concerns of a single system very little is actually known, and answers tend to be mostly in the nature of impressionistic beliefs and vague hypotheses. One such belief, frequently voiced, is that the rules of evidence under the common law adversary system of criminal procedure present much more formidable barriers to conviction than do corresponding rules in the non-adversary civil law system. This belief is then related to a more general feeling that the "higher evidentiary barricades" to conviction somehow emanate from the very nature of adversary proceedings and that their lowering smacks of the "inquisitorial" continental procedure. ${ }^{1}$ Both beliefs are interesting to a comparatist.

${ }^{1} \mathrm{~A}$ recent example of such views can be found in the vigorous dissent of Justice 
Consider first the comparison of evidentiary barriers. Even if a comparatist is skeptical about whether, in their practical implementation, evidentiary rules present very high barriers to conviction in any modern criminal justice system, he will still have to recognize that there might be less prominent differences among systems concerning the difficulty of proving the defendant's guilt. If these differences actually exist, their importance probably exceeds the relatively narrow and technical field of evidence. True, it would be fallacious to infer from a finding of relatively high evidentiary obstacles, that the criminal justice system as a whole will find it difficult to maintain a high conviction rate. For it is possible, for instance, that grave evidentiary problems arising for the prosecutor under one mode of proceedings within a system will be instrumental in the development of alternative and less demanding ways of processing criminal cases. ${ }^{2}$ Similarly, it would be erroneous to infer from relatively high evidentiary obstacles to conviction that, as a result, the factfinding precision within the system is also high. Higher barriers to conviction not only decrease the chances that an innocent person may be convicted but-perhaps in equal measure-also increase the chances that the guilty may escape punishment. Hence, by letting more guilty persons go free, the factfinding precision in the total volume of criminal cases may remain unaffected or even be decreased. Notwithstanding all these limitations on drawing broad conclusions from a narrow evidentiary point, the comparison of evidentiary obstacles to conviction still seems to have a larger significance. For it seems reasonable to assume that unequal evidentiary difficulties in proving guilt, if indeed they exist, have broader implications which somehow transcend the narrow bounds of the law of evidence and affect the working of the whole machinery of criminal justice. Perhaps they even exert an influence on the shaping of doctrines and rules of substantive criminal law.

Assuming that the two evidentiary styles, that of the common and that of the civil law, generate disparate problems of proving guilt, can this phenomenon be related to the opposition between the ad-

Douglas in Johnson v. Louisiana, 406 U.S. 356, and Apodaca v. Oregon, 406 U.S. 404, at 406 U.S. 380 (1972). Believing that the rule requiring a unanimous jury verdict is essential to the effective operation of the standard of proof beyond a reasonable doubt, the Justice expressed his concern that the abandonment of the unanimity rule may "lower the barricades" against easy conviction. The fact-determining process, he felt, may become "stacked" against the accused and a step taken away from the accusatory system, presumably in the direction of continental "inquisitorial" procedure.

2 Suffice it to say here that, in a system like that of the United States, where the overwhelming majority of criminal defendants plead guilty and the need for trial is thus obviated, see Task Force on the Administration of Justice, Presment's Conanission on Law ENForcenent and Administration of Justice, Task Force Report: THE CoURTs 134-35 (1967), prosecutors may be quite effective in obtaining convictions in spite of carefully cultivated protective rules of evidence. 
versary and non-adversary models of criminal procedure? This is the second major question of interest to the comparatist. In an age so fascinated with constructing models it is tempting to test their explanatory force in the highly technical field of comparative law of evidence. Equally interesting, perhaps, is the necessary propaedeutic to any such pursuit: one must seek to ascertain-and the task is a difficult one from either the civil or common law perspective-which procedural ideas and structural patterns are embraced by the two broad classificatory labels of "adversary" and "non-adversary" procedure. Thus, before exploring the possible relationship between procedural models and evidentiary obstacles to conviction, one has to give, adapting Mallarmé's phrase to another purpose, "un sens plus pur aux mots de la tribu."

The comparative study which follows will be in two parts. In the first, more technical part, I shall contrast difficulties in proving guilt that arise under the evidentiary rules of the common law and civil law systems, in an attempt to test the validity of the general impression concerning unequal obstacles to a successful prosecution.

But consider some of the problems involved in the comparison. Within each of the two general legal systems, that of common and that of civil law, proof processes change as we move from jurisdiction to jurisdiction. It is therefore only on a rather general level that styles of factfinding exhibit certain common characteristics. Nor are evidentiary rules applied with equal rigor in all types of criminal cases, even within a single jurisdiction. An additional difficulty resides in the fact that, at least at first blush, there is so much highly complex law on the common law side and so little law on the civil law side. Also, there is in the law of evidence a very pronounced disparity between the law on the books and actual practice. Everywhere so many tendencies seem to be at work, often operating in opposite directions, that one is tempted to suspect that a kind of self-canceling Brownian motion may be the end-result. Finally, conceptual tools and systematic arrangements in the civil and common law differ so widely in the evidentiary field, that one finds oneself groping for common denominators in order to make issues comparable..$^{3}$ All these difficulties require that I make

3 It is, of course, tempting to look for comparative statistics on the percentages of prosecutions resulting in conviction in the two systems as an indicator of relative evidentiary difficulties confronting prosecutors. Unfortunately, reliable and comparable statistics on this score have not yet been compiled. But, even if such statistics were available, it would be dangerous to draw far-reaching inferences from them in an attempt to facilitate our inquiry here. The issues involved are highly complex. The screening and selection of cases for trial is done in different ways in the two systems. For example, the impact of the continental pretrial investigation would have to be correlated with the effect of plea bargaining. Many other variables will become apparent as I continue the discussion in the text. 
a few introductory remarks and a number of reservations before $I$ proceed to unveil the outline of this study.

The first remark concerns the problem of evidentiary styles. Do distinct common and civil law evidentiary styles in fact exist, or are they merely an invention of scholars? As I see it, they do exist and they emerge from the confluence of three main factors. The first one is the opposition, already alluded to, between adversary and nonadversary procedures. It produces, inter alia, such important contrasts as the presentation of evidence solely by the parties as opposed to the production of evidence by the judge. The second factor stems from the difference in the structure of the adjudicating bodies. While in the Anglo-American orbit rules of evidence were responsive to the demands of trials to a jury of laymen, continental rules were tailored to meet the needs of the mixed tribunal. ${ }^{4}$ Obviously, dissimilar evidentiary problems arise in a system where guilt is determined by a body of laymen, and in a system where guilt is established by a tribunal on

Despite all these reservations, the reader might still want at least some statistical data as an illustration. Consider, then, statistics compiled for the French Cours d'Assises, graciously made available to me by Mlle. Yvonne Marx, Centre Français de Droit Comparé, Paris. Those courts, which are not typical of continental adjudicative bodies, see note 4 infra, are rough analogues of the common law court sitting with a jury: three professional judges join nine jurors and decide both the issue of guilt and the sentence. In 1967, only $5.29 \%$ of the defendants were acquitted by the Cours d'Assises; in 1968, $6.81 \%$; and in $1969,6.08 \%$. As types of disposition other than those on the merits are virtually nonexistent and statistically negligible, the reader may assume that in all remaining cases defendants were convicted by the French courts. Now, if one bears in mind that, over the same period, taking acquittals and dismissals together, only about $70 \%$ of defendants were convicted in the United States federal district courts, one would be tempted to assume that these differences are very significant. I do not think, however, that, in the absence of further analysis, such facile statistical comparisons have any real meaning.

If, on the other hand, comparison of meaningful conviction/acquittal ratios, here and on the Continent, did not reveal any significant differences, it would nonetheless be hasty to conclude that prosecutorial evidentiary barriers too are not significantly disparate. That would be similar to insisting that two runners assigned different obstacle courses cannot cross the finishing lines at the same time.

4 The jury trial was transplanted to the Continent at the time of the French Revolution and in the wake of continental enthusiasm with English institutions. Somewhat modified from the very beginning (for example, there was never a requirement of unanimity), the continental jury never really became acculturated and soon suffered a decline, for reasons admirably related in Mannheim, Trial by Jury in Modern Continental Criminal Lare, 53 L.Q. Rev. 99, 388 (1937). At present the jury trial has been retained only in a small number of Western European countries (Austria, Belgium, Norway and a few Swiss cantons) for the disposition of a narrow class of criminal offenses. Although Lenin had a few kind words to say about the pre-revolutionary jury in Tsarist Russia, trial by jury was not adopted following the revolution of 1917. See 4 V. LENIN, SOCHINENIYA [SELECTED WORKS] 83-84 (2d ed. 1928). Nor have socialist countries of Eastern Europe opted for the jury trial.

The prevailing contemporary continental system is that of a unified bench in which the professional judge or judges are flanked by lay assessors. Even in France, after the reforms of 1941, the "jurors" deliberate and vote with the professional judges, so that the system remains that of "jury trial" in name only. Adjudication solely by professional judges, while not unknown (for example, such is the practice in the Netherlands), is usually employed in the disposition of minor offenses and is definitely not representative of the modern continental style. In sum, the continental law of evidence is most profitably examined against the background of trial by a mixed tribunal. 
which lay and learned judges sit and deliberate together. The third and final factor contributing to the emergence of distinct evidentiary styles reduces to the circumstance whether or not the trial is preceded by a purportedly non-partisan investigation, the results of which are available to the judges. Imagine only the numerous consequences stemming from the contrast between a factfinder who begins the trial sterilized of any prior knowledge of the case and operates initially in a factual vacuum, and a factinder who is familiarized in advance of the trial with summarized records of all testimony taken during the preliminary investigation. The evidentiary style emerging from the compenetration of these three main factors leads me to the first important reservation. In cataloguing and contrasting evidentiary hindrances to a successful prosecution, I shall focus only on those aspects of the proof-taking process which seem to me characteristic of the respective evidentiary style. True, adopting this limitation gives rise to the apprehension that representational accuracy may be diminished, but, at the same time, it enables me to extract and contrast the more salient features of each style while avoiding fruitless analysis of minutiae.

If the first reservation decreases the precision of my exposition, the second is designed to increase it. Jurisdictions in both the common law and the civil law systems, of course, have evolved several methods, of varying degrees of formality, for processing criminal cases. In most continental countries streamlined proceedings were devised for the adjudication of less serious offenses, while more elaborate procedures were designed for the disposition of cases involving serious crimes. ${ }^{5}$ However, the continental defendant does not decide which type of processing will be followed in his case; the nature of the offense in-

5 Many continental countries distinguish between "criminal" and "noncriminal" offenses, notably in the area of traffic, economic, and public nuisance offenses. Conduct characterized as "noncriminal" (which often would be deemed "criminal" in America) is handled by administrative agencies, the evidentiary rules of "which are less demanding than those encountered in the processing of criminal offenses. But even in the realm of criminal offenses proper, crimes of different gravity (in terms of penalties authorized) are usually entrusted to courts of differing original jurisdiction, and somewhat different procedural and evidentiary rules apply. The less serious the crime, the less elaborate the rules. See, e.g., The Geraran Code of Crominat Procedure \$ 407 (The American Series of Foreign Penal Codes, No. 10, H. Niebler transl. 1965) [hereinafter cited as West Geratan Code]; Code of Crtamnal Procedure art. 392 (Collection of Yugoslav Laws XIX, M. Damaška transl., Belgrade 1969) (Yugoslavia) [hereinafter cited as YugosLAV Code of Crmminal Procedure].

In France, where the distinction between administrative offenses and criminal offenses has traditionally been rejected, analogous developments in the evidentiary field took place. Thus, before the Cours d'Assises, which try the most serious crimes, quite stringent evidentiary rules apply. The latter are somewhat relaxed in cases of median gravity, considered by the Tribunal de Grande Instance. Still less demanding, at the bottom of the judicial hierarchy, are Tribunaux d'Instance which have jurisdiction over cases that would in the majority of other continental jurisdictions be classified as mere administrative offenses. See, e.g., Statute No. 72-5 of Jan. 3, 1972, 92 Gazette du Palais No. 1, at 58 (1972). See generally 2 G. Stefant \& G. Lavasseur, Drott PÉNaI GÉnéral et ProCÉDURe PéNALE 460 (2d ed. 1966). 
volved is decisive. In common law jurisdictions, meanwhile, it is the defendant who determines the type of proceeding in which his case will be processed, by using the pleading mechanism and by exercising waiver. Neglecting this by no means unimportant difference, ${ }^{6} \mathrm{I}$ shall limit my comparison of prosecutorial evidentiary difficulties encountered in prosecution only to those problems which arise in the processing of cases where the full panoply of evidentiary rules applies. Accordingly, cases tried to a common law jury, a miniscule fragment of the totality of criminal cases, will be contrasted with continental criminal cases involving serious offenses, also only a segment of the total picture. I believe that this second limitation will prove not to be too disappointing to the reader. I impose it in part because the possibility of having to try a case to a jury influences both the law of evidence and substantive criminal doctrines of common law jurisdictions. More important, limitation to this small sector of the whole tableau will hopefully provide the right starting point from which to undertake a more comprehensive comparison of criminal justice systems.

In organizing the first part of the present study, adjudicative factfinding activities will be divided, like Caesar's Gaul, into three parts: activities preparatory to proof-taking, actual proof-taking, and the weighing or evaluation of evidence. Evidentiary barriers to a successful prosecution arising in each phase will be analyzed separately in full awareness that related processes are thus examined in artificial isolation. But, before I close the first part of my study, the results of the analysis will be placed in a larger context and its implications briefly surveyed. After drying my theme in the closet of evidentiary technicalities, I will place it in a broader, more natural habitat. Hopefully, it will then regain its proper dimensions and its vitality.

Since my conclusion in the first part of the Article is that the fullfledged common law trial does place somewhat higher evidentiary barriers to conviction than does its continental counterpart, I shall reflect, in the second part, on the possible nexus between this phenomenon and the opposition between adversary and non-adversary procedures. Of course, one cannot set his mind free to speculate about this theme before obtaining a sufficiently clear idea of the essential characteristics of adversary and non-adversary types of procedure. Unfortunately, as

${ }^{6}$ Under the American system, for instance, the defendant, by refusing to plead guilty and to waive the jury trial, can cause a relatively minor case to be processed in the most elaborate, costly and time-consuming manner. On the Continent, simplified procedural patterns are utilized in the disposition of less serious cases, and the defendant cannot compel the court to dispose of the case either in a more or a less elaborate manner than that prescribed for the type of crime in question. The implications of this difference in approach will be explored later, see notes 97-101 infra \& accompanying text. 
the reader will see, there is more than the usual degree of confusion on this score. The terms "adversary" or "accusatorial" and "non-adversary" or "inquisitorial" are assigned, both here and in Europe, a variety of loose meanings. Therefore, before hazarding a few thoughts on the relationship between evidentiary barriers and procedural models, I shall have to discuss the most important ways in which the opposition of the two rival models can be conceived, and attempt to isolate the opposition most fruitful for the purpose of this comparative study.

Having completed this preliminary work, I shall then argue that the level of evidentiary obstacles which prosecutors face in the two systems may well be related to the nature of the two rival procedural models, in that the latter are committed to an unequal degree to the pursuit of truth. Whether or not the two models in fact set different store by the discovery of truth will be discussed in the last sections of the present study. In this manner, the explanatory force of procedural models will be tested in a narrow technical field, and both "myopic and panoramic vision cultivated simultaneously."

\section{Comparison of Evidentiary Barriers to Conviction}

\section{A. Activities Preliminary to Proof-taking}

In both the civil law and the common law systems the judge must first decide what evidence will be examined at trial. It is here that we encounter one of the most often repeated generalizations in comparative discussion of the law of evidence. It is said that while common law systems are mainly concerned with the issue of admissibility, civil law systems admit all evidence that is logically relevant. It is tempting to hypothesize from this that on the common law side of our comparison the prosecutor experiences greater difficulties than his continental counterpart in transforming his informational sources into admissible evidence. As usual, closer examination tends to lead to qualifications and refinements. Do they destroy the generalization?

In seeking an answer to this question, two kinds of exclusionary rules will, for the sake of clarity, be held apart throughout my discussion of this initial phase of adjudicative factfinding. First, evidence may, of course, be excluded because of the belief that it may impede the pursuit of truth. But, second, it may also be excluded for reasons extraneous to truth-finding considerations and often at odds with them, as in the case of reliable evidence obtained in an illegal manner. I begin with evidence excluded under the first rationale.

712 A. Toynbee, A Study of History, Reconsmerations 132 (1961). 


\section{Admissibility Rules Designed to Improve Factfinding Accuracy}

Evidence which has passed the test of logical relevancy and has been found suitable for rational inference may still fail to be admitted under the common law rules of evidence. Some of these rules, more rooted in experience than inspired by $\operatorname{logic}^{8}$ exclude certain classes of logically relevant evidence, largely on the theory that its impact on the trier of facts may be stronger than its actual probative weight. In contrast, continental law does not contain rules excluding relevant evidence on the ground that factfinders might erroneously assess its credibility and thus endanger factfinding precision. This is not the place to enter into a discussion of how much of this omission is due to the fact that continental decisionmakers are not solely untrained citizens and how much is due to other reasons. ${ }^{9}$ The fact is that lawyers trained in the civil law system are nearly unanimous in their rejection of this first type of exclusionary rules. They seem more optimistic than their common law brethren that the factfinders, lay or professional, will be capable of disregarding the influence of relevant but untrustworthy evidence-for example, some types of hearsay-and, having heard it, exclude it from the calculus of decision. Paradoxically, in view of their general attitude toward anticipating the future by legislation, they are more pessimistic than common law lawyers about the wisdom of framing general rules rather than relying on a case-by-case approach. They do not believe that it is possible to frame successfully legal rules based on expectations about the impact of certain classes of evidence. "These are good rules of thumb in an average case," they might say when confronted with common law rules of admissibility, "and perhaps professional judges could use them to good advantage when debating evidence informally with lay judges, in situations in which the concrete circumstances of the case at hand seem to make the rules applicable.

8 See 4 J. Wigmore, Evidence § 1171, at 395 (Chadbourn rev. 1972). Examples in point would be the hearsay rules and the general prohibition against informing the trier of fact of an accused's prior criminal record.

9 The discussion here centers primarily on the presence, as opposed to reasons for the absence, of hearsay rules. Many scholars attribute these rules to the existence of the jury trial, but this view is questioned by others. In any event, many common law lawyers currently find exclusionary rules, although somewhat modified, to be imperative even in nonjury cases. See generally Levin \& Cohen, The Exchusionary Rules in Nonjury Criminal Cases, 119 U. PA. L. Rev. 905 (1971).

Those who believe that the exclusionary rules are a necessary corollary of the jury trial will probably classify it as one of the ironies of history that the transplantationlargely -rejected later, see note 4 supra - of the jury trial to the Continent signaled the end of a comprehensive system of evidentiary law. Throughout its history on the Continent, the transplanted jury trial operated without an analogue of common law exclusionary rules. For an explanation of this curious phenomenon, see Hammeimann, Hearsay Evidence: A Comparison, 67 L.Q. REv. 67 (1951). 
However, it is not wise to ossify them into rules of law."10 Obviously, then, common law lawyers will search the civil law in vain for the hearsay rule, rules excluding gruesome or inflammatory evidence, and similar rules of "auxiliary probative policy."11 They will also be surprised or even shocked to find that, although the defendant is said to

10 How can continental rule-skepticism in the evidentiary area be explained? Some will, no doubt, be inclined to view this phenomenon as rooted in the alleged continental desire to reduce technical complexity in processing criminal cases to a minimum, and thus "lower the barriers" to conviction. The historical perspective suggests, however, a much less dramatic explanation: that the skepticism is a response to bad experiences under the medieval system of legal proof.

Medieval evidentiary law, designed for use in the inquisitorial procedure, was basically the same all over the Continent. Strikingly characteristic of this law were rigid rules concerning the quantity and quality of proof needed for a conviction. Circumstantial evidence alone was regarded as insufficient proof of guilt in "ordinary" (mostly capital) cases. The defendant could be convicted only upon the testimony of two unimpeachable eyewitnesses or upon his (usually corroborated) confession. Where the investigator gathered the legally required evidence, the court was legally bound to convict, irrespective of its subjective evaluation of that evidence. The reverse was, of course, also true. No matter how persuaded of the defendant's guilt on the basis of circumstantial or legally defective direct evidence, the medieval court was not authorized to convict and sentence to the "ordinary punishment" (for the most part, death). For an excellent discussion of these rules in their French variant, see A. ESMTEIN, HISTOIRE DE IA PROCÉDURE CRTATNELLE EN FRANCE 260-83 (Frankfurt-am-Main 1969) (photocopy of the 1882 Paris edition). The underlying policy of this system of legal proof is expressed with great clarity in M. Cappelietri, J. Mierryaran \& J. Permlo, The Italian Legal System 13942 (1967), but the reader should bear in mind that this exposition deals with legal proof in civil procedure, where there was more emphasis on "numerical jurisprudence" and more juggling with "proof-fractions."

Although late into modernity many, like Leibnitz, believed that comprehensive rules could be framed determining a priori the weight of evidentiary material, dissatisfaction with the medieval system of legal proof in criminal matters reached its high point at the time of the Enlightenment. There were two primary criticisms. First, the factfinders' ability to make a subjective evaluation of the evidence was disregarded. Second, the rigid and very demanding standards of proof in cases involving major crimes brought about the widespread use of torture, which, because of the unavailability of two unimpeachable witnesses, was often the sole means of obtaining the required proof for conviction-the defendant's confession. See note 215 infra.

Following the French Revolution the so-called system of "free evaluation of evidence" replaced the medieval system of legal proof. Both rules affixing a priori weights to evidence and rules requiring how many and which pieces of evidence must be gathered for conviction were stricken from the books. The inspiration of these reforms was not a desire to "lower the barriers" to conviction, but rather a desire to improve the defendant's lot and, more generally, to further factfinding precision. But, and this is of particular importance, the rejection of these rules was predicated on the belief that it is impossible to determine satisfactorily in advance the impact of particular evidentiary material on the factfinder.

It now becomes obvious why continental systems reject not only rules assigning wright to evidence but also rules excluding evidence for the purpose of improving factfinding precision. Although the two types of rules are analytically different, they are both based on the theory that one can satisfactorily draft rules of evidence anticipating the impact of specific classes of evidence on the factfinder. The difference is only that one type of rule says to the trier of fact, "This is reliable evidence and you must attach such-and-such weight to it," while the other says to him, "This is spurious evidence and you may not even consider it."

11 This is Wigmore's term. See J. WigMore, supra note 8 , § 1171, at 395.

For the sake of comprehensive presentation I should note that there are a few basically civilian jurisdictions which consider hearsay evidence ordinarily inadmissible. Thus, in Japan hearsay will not be admitted in the most formal type of proceedings unless the opposing party consents to it. See The Code of Crintnar Procedure arts. 320, 326-27 (compiled by Liaison Section, General Secretariat, Supreme Court (Japan) 1949). This, however, is clearly outside the main current of the civil law. 
have the right to lie, ${ }^{12}$ he is freely examined for evidentiary purposes and not required to take an oath. ${ }^{13}$

No matter how important the difference between the two systems due to the absence in civil law of these exclusionary rules, the distance may easily be overstated and even misunderstood. Various devices leading to the exclusion of relevant evidence were developed on the Continent so that not all evidence that is to a continental lawyer relevant is ipso facto admissible. The comparatist must detect these devices disguised by different labels and ascertain exclusionary side-effects of procedural rules designed by continentals to achieve other purposes.

Let me quickly survey some of these devices. In all continental jurisdictions the judge has the power, seldom defined with precision by written law, to refuse examination of evidence even though it appears logically relevant and there is no specific exclusionary rule in point. For instance, in many European jurisdictions the judge may refuse to hear witnesses if there is reason to believe that, even if the witnesses confirmed the contention of the party, their testimony would have no influence on the fact-determination. ${ }^{14}$ By means of this important

12 See note 44 infra.

13 The "prophylactic" rule requiring that the defendant testify under oath is regarded by continentals as unnecessary. The oath, they argue, will not prevent the guilty defendant from perjuring himself. Further, factfinders will take the defendant's unsworn statement with a grain of salt in any event, and will draw useful inferences even from his lies.

Perhaps more importantly, the requirement that the defendant testify under oath is considered by continental lawyers as undesirable and unfair. It is precisely on this score that lawyers from both Western and Eastern Europe criticize the common law require. ment as "inquisitorial." For an example of Soviet views on this point see N. AtersSEev \& V. LURASHEVICS, LENINSKIE IDEI V SOVETSKOM UgOLOVNOM SUDOPROLZVODSTVE [LENINIST Ideas In Soviet Crmatnat Proceentngs] 183 (1970). What is the thrust of the criticism? The requirement of oath is said to be an unfair pressure on the guilty defendant either to convict himself out of his own mouth by telling the truth, or else to suffer punishment for perjury by lying. In view of the incentive to testify so as to avoid possible unfavorable inferences from his failure to take the witness stand, the defendant often has little opportunity to avoid this "agonizing" alternative. Placing him in this predicament is even termed "inhumane." $C f_{.} 2$ P. Bouzat \& J. PINATEL, Traité de Droit PÉNAI ET DE CRTMInologIE 944 (1963). In the language of Garrity v. New Jersey, 385 U.S. 493 (1967), relating to a context not so remote from ours as it might appear at first blush, see note 40 infra, the common law defendant is viewed by continental lawyers as "having a choice between the rock and the whirlpool." Few continentals realize that it is the fear of exposing the factfinder to unreliable evidence which underlies the oath requirement. But even if they were aware that the explanation lies in what Wigmore termed "prophylactic rules of admissibility," J. WIGMORE, supra note 8, $\$ 1172$, at 397 , the strength of their belief on this point is so great that I do not believe they would retract their criticism.

14 For example, the court may refuse to hear a witness because it is already thoroughly convinced of the factual proposition the party purports to prove, It must be borne in mind that the continental mixed panel decides both the question of admissibility and the ultimate question of guilt. Thus, decisions to deny a motion to examine an item of evidence often amount to an interlocutory verdict. For an extensive comparative discussion of this problem, see E. KREUZER, DIE BESTIMTNUNG DES UMCFANGS DER BEWEISAUENAFHME IM DEUTSCHEN, FRANZÖSISCEEN UND ITALIENISCEEN STRAFPROZESS 77 et seg. (1964). 
power accorded to the continental trial judge, many items of evidence, inadmissible under the common law rules (such as, for example, multiple hearsay), will, as a rule, be inadmissible in the continental court as well.

Another continental device exerting an exclusionary effect is the so-called "principle of immediacy." It reflects a violent reaction against a much criticized feature of the medieval inquisitorial procedure. The examiner who conducted the secret "inquisitio" was required to put in the record every procedural step taken and all evidence heard. The official "dossier" (acta inquisitionis) thus contained minutes describing, among other things, the results of proof-taking. At the close of the investigation the file was, in all serious criminal cases, transmitted to a panel of judges who based their decision solely or primarily on evidentiary items contained in the dossier. The judges seldom, if ever, came into personal contact with the defendant or the witnesses. The realization that "original" evidence is more probative than evidence filtered through intermediary sources led to the adoption in modern continental procedures of the principle that evidentiary sources be examined by the decisionmaker in their original rather than derivative form. Perhaps the principle can best be explained to common law lawyers as an extension of the "best evidence rule" to all types of evidence. The precise meaning and reach of the principle vary as we go from continental jurisdiction to jurisdiction and it is generally one of preference only. ${ }^{15}$ But, no matter how restricted the meaning of the principle, it will often require the judge to examine the original declarant of a statement. Clearly, then, at least some evidence which is excluded in common law countries as verbal or written hearsay will be rejected by the continental courts as violative of the "principle of immediacy."16 Considering that on the common law side of our compari-

15 In probably the majority of continental jurisdictions the principle is construed narrowly, solely as a device to eliminate the documentary curtain from the trial. Thus, whenever possible, witnesses must be produced in court in place of introducing their prior testimony. In West Germany, however, the principle is interpreted more broadly so as to prohibit, inter alia, the examination of a hearsay witness with respect to the truth of the statement he has heard, at least as long as there is an eyewitness available. The hearsay witness may, however, be examined with respect to the fact that he has heard the original statement. In this respect he is treated as an eyewitness regarding

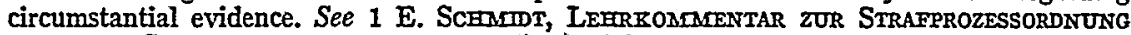
UND ZOM GERTCETSVERFASSUNGSGESETZ 254 (1964).

10 It must be noted in passing that continentai legal doctrine often exaggerates the extent to which the principle of immediacy actually reduces the impact of evidence examined during the pre-trial stages of the criminal process. Consider only that the typical continental presiding judge is expected to study the dossier in advance of the trial: without familiarity with documents contained therein he could hardly be efficient in carrying out interrogations. It would be unrealistic to deny that the dossier leaves at least some imprint upon the mind of the presiding judge, who is, in turn, a very influential member of the continental mixed tribunal. On this problem see Jescheck, Germany, in Tne Accused: A Comparative StUdy 246, 247 (J. Coutts ed. 1966). A 
son there are numerous exceptions to the hearsay rule, with all the obscurity of their refinements, the gap between the two systems on the issue of using hearsay is not as wide as might appear at first sight.

It is also easy to attach too much significance to the absence in the civil law of rules excluding the defendant's prior criminal record and evidence of other crimes of which he has not been convicted. Continental judges will agree with their common law brethren that the defendant's prior criminal record per se should not play a part in the guilt determination as proof of a propensity toward criminal activity. The explanation will, however, be different, exemplifying the fact that some problems, which in common law jurisdictions would be posed as questions of admissibility, are treated by civilian lawyers as problems of logical relevancy. For example, continentals would simply say that the prior criminal record per se, that is, without regard to its possible value as circumstantial evidence, is irrelevant because it is unsuitable for logical inference. Only if, as in proof of modus operandi, a prior conviction permits rational inferences, will continental judges use it for evidentiary purposes. ${ }^{17}$ Further, the continental judge will refuse to hear evidence of other crimes with which the defendant has not been formally charged or of which the defendant has not yet been convicted. The presumption of innocence will be said to preclude the possibility of according any weight to as yet undetermined criminal activity, and the latter cannot be determined in court as it was not charged. ${ }^{18}$ In con-

minority of continental jurisdictions have entrusted the examination of witnesses primarily to the parties and only subsidiarily to the judge (e.g., some Scandinavian countries and four constituent republics of the USSR). Under this system familiarity on the part of the presiding judge with the dossier is no longer imperative. There is only one basically civil law jurisdiction known to me where the presiding judge must begin the interrogation although he knows nothing about the case: Japan. This arrangement is, however, termed "illogical" even by Japanese authorities. See S. Dando, Japanese Crtamtnat, Procedure 374 (B. George transl. 1965). Other factors operating so as to reduce the practical importance of the immediacy principle arise from exceptions to it. See note 19 infra.

17 All this is not to say that practically important differences do not remain. Thus, for instance, continental lawyers will attribute a broader meaning to "modus operandi." Consider as an illustration the "Karlsrühe case," so vividly described in S. BEDFORD, THE Faces of JUSTICE (1961). In offering support for his judgment in this case, the West German judge denies that he accorded any weight to prior convictions per se. He draws inferences, however, from the modus operandi established in prior proceedings: all prior thefts were "stupid, impulsive actions prompted by sudden temptation, doomed to failure," id. 180. This particular formulation of modus operandi would not seem to common law lawyers "so unusual and distinctive as to be like a signature," in McCormick's felicitous phrase. McCorancr's HANDBOOK OF THE LAW OF EvIDENCE \$ 190, at 449 (2d ed. 1972).

Specific references to the use of prior criminal records as evidence are seldom found in continental legislation. But see WeST German CODE, supra note 5, \& 243, and the comments thereon in T. KIEINKNECHT, STRAFPROZESSORDNONG 580 (29th ed. 1970). As there is in continental law no "impeachment" of the defendant in the strict technical sense, and as he is under no legal obligation to testify truthfully, see note 41 infra, the use at common law of prior criminal record to impeach a witness' credibility has no precise parallel in continental criminal evidentiary law.

18 In order to understand this difference, the contrasting procedural contexts must 
trast, common law jurisdictions admit such evidence under certain circumstances. Thus, though continental law, unlike the common law, contains no express prohibition against introduction of these sorts of evidence, it may be that, as a practical matter, it is more restrictive than the common law in this regard. The fact remains, however, that the continental judge will always be familiar with the defendant's prior criminal record in advance of the decision on guilt. It is not too farfetched to imagine that this knowledge may tip the scales against the continental defendant in some close cases where the common law defendant would be acquitted, despite the proclamation of the continental legal folklore that the prior record is logically irrelevant.

It thus appears that the two systems are not so far apart concerning this first type of admissibility rules. Counter-tendencies to basic orientations narrow the gap on both sides. Yet there is no gainsaying that a great deal of information, inadmissible under common law evidentiary rules, reaches the continental adjudicators. Consequently, the prosecutor in the civil law system will often find it less difficult than his common law counterpart to squeeze his informational sources into the corset of technical rules of evidence.

For our purposes, perhaps the most important residual difference is the relatively greater ease with which the continental prosecutor can introduce evidence of out-of-court declarations of witnesses. In virtually all jurisdictions testimony recorded at the pre-trial examination, and often even prior to that, during the initial police inquiry, may be used in court for substantive evidentiary purposes. ${ }^{10}$ The continental prose-

be borne in mind. In perhaps the majority of continental systems the prosecutor is required by law to prosecute whenever there is sufficient evidence of crime. Moreover, joinder of offenses is mandatory. Thus, the judge is actually telling the prosecutor, "If you have credible evidence of related crimes committed by the defendant, go ahead and bring charges." True, sometimes it becomes absolutely necessary in a criminal case to prove a fact or set of facts falling partly under another category of crime (e.g., in order to trace a murder weapon stolen from a store to the defendant). Then this fact or set of facts, rather than the offense as such, will be subject to proof in court.

19 True, evidence which has not been brought out during trial may not be used in arriving at the decision. Evidentiary material contained in the dossier technically does not constitute evidence, although it does in fact influence the presiding judge and, through him, other members of the adjudicating panel. But, even disregarding actual practice, once evidence contained in the dossier has been brought out (by reading out summaries of interrogation or in some other way), it may legally be used for substantive purposes. See, e.g., West Geraran Code, supra note 5, \$§ 251, 253 and comments thereon in $T$. KIEINKNECET, supra note 17, at 624. Information on Italian law may be found in A. De Marsico, Diritto Processuale Penate 243 (1966); for French law see 2 P. Bouzat \& J. Pinater, supra note 13, at 952. See also Yugostav CODE OF CRIMITnat Procedure, supra note 5, arts. 301, 305. The practice of liberally using prior inconsistent statements for substantive purposes is sometimes criticized, but mostly by academic lawyers. See, e.g., 2 E. Scmarmr, supra note 15 , commentary to $\$ 253$, at 723. Even if a witness has not been interrogated before the trial, the substance of his testimony can, under some reservations, be introduced through the testimony of hearsay witnesses, such as police officers.

Depositions of witnesses made during the preliminary examination can be used at trial under the English variant of common law criminal procedures. To the extent to 
cutor is, therefore, capable of "freezing" a great deal of crucial incriminating evidence well in advance of the trial. The extent to which this circumstance explains the difference in attitudes toward actual and potential witnesses in the two systems is too apparent to belabor. ${ }^{20}$

An argument may be anticipated here that no matter what the differences between the two systems on this score, they are irrelevant for our purposes. Exclusionary rules of the type now under discussion make it more difficult to prove factual propositions. These, however, can be favorable as well as detrimental for the defense. Accordingly, the argument continues, if exclusionary rules create special obstacles to the prosecution, they also affect the defense in the same way. The conclusion is that these difficulties cancel each other out and the diffculties in obtaining a conviction remain the same.

Whether the first type of exclusionary rules affect both parties in the same way is not easy to say. The constitutional right of the American defendant to confront witnesses, for instance, could, if stretched to its full potential, prevent the prosecution from using quite a number of hearsay exceptions while still allowing the defense to use all of them. This would then mean that admissibility rules hamper the prosecution more than they do the defense. However, this potential of the confrontation rule, advocated by some, has not been realized. ${ }^{21}$ Besides, many cognoscenti suspect that hearsay exceptions display a prosecutorial bias to start with. The outcome of these and some other opposing tendencies ${ }^{22}$ is unclear, and the argument about the mutually cancelling

which this is permissible, testimony obtained in advance of the trial may be preserved for later use. However, the conditions under which such depositions may be put in evidence are much stricter in England than on the Continent. For example, it must be proved that the defendant was present when witnesses gave evidence and that he had the opportunity to cross-examine them. For elaboration see KenNY's OUTLINes of Crimmat Law 511 (18th ed. C. Turner 1962).

20 For example, the motivation to bribe or intimidate potential witnesses will be diminished in that their testimony has in a sense been "canned" for use at trial. The absence of "material witnesses" in the civil law is only one of many other less visible consequences. But, surely, the implications of this "freezing" of testimony at an early stage in the criminal process have a broader range. They affect, for instance, attitudes toward full pre-trial disclosure of evidence. At least some opposition to full disclosure comes from the fear that evidence will be tampered with.

21 The strong exclusionary effect of the confrontation rules has recently been advocated by Seidelson, Hearsay Exceptions and the Sixth Amendment, 40 Geo. WASE. I. REV. 76, 89 (1971). But see Griswold, The Due Process Revolution and Confrontation, 119 U. PA. L. REV. 711 (1971).

22 Perhaps one of them deserves mention here. It revolves around the impact on the law of evidence of the lack of appeals from an acquittal. This is the rule in most common law jurisdictions, while the opposite is the case on the Continent. Some would be prepared to argue that this circumstance must in the long run inject a pro-defense bias into the law of evidence. In an effort to avoid reversals, the common law trial judge might lean in the direction of excluding relevant evidence for the prosecution whenever its admissibility is doubtful, while giving great latitude to the defense. See G. WIIIAMS, THe Proof of GUIIT 327 (1963). Others would make an equally plausible argument that the judges tend to rule in favor of the prosecution in close cases so as to preserve reviewability of their rulings. Note in this connection that Williams considers hearsay to be admissible evidence for the defense, id. 209-10. 
effect may perhaps be correct. But when we place the issue in the context of trial mechanics, a new dimension appears. The prosecutor at common law is the first to produce evidence and, in order to reach the trier of fact at all, he is the first to be stretched out on the Procrustean bed of the exclusionary rules. Prior to trial, in contemplating whether to bring charges formally against a defendant, he must ask himself whether the logically revelant information he has gathered will successfully undergo the legal metamorphosis into technically competent evidence. This, I submit, is a problem which the continental prosecutor does not face at all, or, if he does, not nearly in equal intensity. ${ }^{23}$ But here I am getting ahead of my story. Before considering the problem of the prosecutorial burden to establish a prima facie case, I must return to admissibility rules and discuss their second type.

\section{Admissibility Rules Governed by Considerations Extraneous to Truth-finding}

The second type of admissibility rules, leading to exclusion of evidentiary material irrespective of its reliability, is not unknown to the civil law systems. However, it would be erroneous to assume that both systems exclude roughly the same amount of evidence by virtue of the operation of these rules. Even if we confined our inquiry solely to comparing statutory proclamations and formal doctrine, it would soon become obvious that exclusionary rules are more numerous and surely much more elaborate in America than they are in any civilian jurisdiction. True, in the field of testimonial privileges the scope of exclusionary rules will not differ significantly. ${ }^{24}$ But, as we take a closer look at

23 Imagine how difficult it would be in many cases for the common law prosecutor to establish a prima facie case without taking advantage of the exception to the hearsay rule in favor of admitting out-of-court confessions of the defendant. It is indeed easier for the continental prosecutor to take a case to court without the confession than it is for his common law colleague. See Kunert, Some Observations on the Origin and Structure of Evidence Rules under the Common Law System and the Civil Law System of "Free Proof" in the German Code of Criminal Procedure, 16 Burf. L. Rev. 122 (1966). Note also the empirical data on the use of confessions by West German courts in Casper \& Zeisel, Lay Jaldges in the German Criminal Coutrts, 1 J. Leg. Srudies 146 (1972).

24 See Pieck, Witness Privilege against Self-Incrimination in the Civil Law, 5 VIIr. L. REV. 375 (1960). It is true that testimonial privileges are quite restricted in a number of European countries (e.g., France and the Soviet Union), but on the other hand some jurisdictions go even beyond what is customary in the common law countries. Consider, as an illustration, Yugoslav Code of Crmminal Procedure, supra note 5, art. 213: "A witness is not under duty to answer particular questions if it is probable that, in answering, he may expose himself or his close relatives to serious disgrace, considerable financial loss or criminal prosecution." Id., art. 215 requires the judge to instruct the witness of his privilege.

The actual exercise of the privilege is quite another matter. Pieck, supra, at 389 , is probably right in his observation that continental witnesses seem to claim the privilege less often than American witnesses. Also, continental lawyers seldom counsel witnesses to use the privilege. In general, their contacts with witnesses outside the courtroom are less frequent than in common law jurisdictions, and are often even frowned upon. 
exclusionary rules concerning defective interrogation of the defendant, the impressions begin to change. ${ }^{25}$ Many continental provisions regulating the interrogation of defendants are silent as to the admissibility of testimony obtained in violation of proper interrogation procedures. This is a significant silence indeed when compared with express exclusionary rules relative to the defective interrogation of persons other than the defendant. Only a small number of continental countries have adopted express legislative provisions rejecting illegally obtained testimony of the defendant. ${ }^{26}$

But the greatest contrasts by far exist in the law of search and seizure. Exclusionary rules in this area are a rarity in continental law and the "poisonous fruit" doctrine sounds almost fantastic to civil law lawyers. ${ }^{27}$ This is all the more remarkable in view of the fact that the continental law of search and seizure is much less restrictive than that of most common law jurisdictions. Thus, for instance, the police can always conduct a warrantless search if there is "danger in delay."28

25 The reader trained in the common law should not hastily assume that views as to what is proper interrogation of the defendant are the same when we leave the Anglo-American legal orbit. The privilege against self-incrimination is not construed in the same way. See notes 39-40 infra \& accompanying text. Let it suffice at this point to offer only one illustration: although most continental procedures accord the defendant the right to remain silent in the face of questioning, not all of them require that the defendant be advised of this right.

26 See, e.g., West German Code, supra note 5, § 136a; The French Code of Crmminal Procedure arts. 114, 118, 170 (The American Series of Foreign Penal Codes, No. 7, G. Kock transl. 1964) [hereinafter cited as FrENCE CoDE]; YUgosLav CodE of CRIMTNAL PROCEDURE, supra note 5, art. 203. For a comparative discussion of jurisdictions favoring admissibility of evidence obtained from the defendant through illegal questioning if that testimony is otherwise reliable, see Damaška, Comparative Reflections on Reading the Amended Yugoslav Code: Interrogation of Defendants in Yugoslav Criminal Procedure, 61 J. Crrac. L.S. \& P.S. 168, 179 n.68 (1970). See also Pieck, The Accused's Privilege against Self-incrimination in the Civil Law, 11 AM. J. CoMp. L. 585 (1962).

Two more brief comments seem in order for those in need of background information. First, a survey of much of the continental writing on defective interrogation of the defendant reveals that departures from the prescribed manner of interrogation are typically considered dangerous to truthfinding. Abiding by the rules of proper interrogation thus seems to be mandated solely by the concern for factfinding precision. Second, in those rare jurisdictions where illegally obtained testimony of the defendant must be excluded irrespective of its credibility, few courts would go so far as to exclude all evidence procured as a "fruit" of an illegally obtained confession. Isolated views to the contrary are mostly voiced by academically rather than forensically oriented lawyers. An example of such a radical view is that of the West German K. Peters. See Peters, Beweisverbote in deutschen Strafverfahren, in VERHANDLUNGEN DES SECHSUNDVIERZIGSTEN DEUTSCEEN JURISTENTAGES 160 (1966).

27 That is, the doctrine that evidence derived from illegally obtained evidence is also inadmissible. See Wong Sun v. United States, 371 U.S. 471 (1963); Nardone v. United States, 308 U.S. 338 (1939).

28 See, e.g., West German Code, supra note 5, § 105; The Code of Crindiatax PROCEDURE OF THE RSFSR art. 168 (H. Berman \& J. Spindler transl. 1966) [hereinafter cited as RuSSIAN CODE of CRIMITAal ProceduRe]; Frencer Code, supra note 26, art. 56.

Regarding objects subject to seizure, it must be emphasized that continental law never limited searches and seizures to "instrumentalities" as opposed to items possessing "mere evidentiary value." After the rejection in 1967 of the mere evidence rule by the Supreme Court, Warden v. Hayden, 387 U.S. 294 (1967), the two systems have drawn closer together on this point. But even where, as in West German law, the list of objects not subject to seizure is quite impressive, there still remain differences of practical 
More important than the black-letter law is, of course, the problem of its practical implementation. Are exclusionary rules more vigorously enforced in common law than in civil law jurisdictions? In the absence of reliable comparative data it is difficult to answer this question. If one were to seek to determine the frequency and vigor with which exclusionary rules are actually implemented on the basis of academic discussions or in the light of the case law emanating from the highest courts, one would be led to believe that the concern over practical implementation, at least in America, greatly exceeds the concern evident in civil law jurisdictions. The volume of American constitutional law on exclusionary rules is clearly without precedent anywhere. Many will argue, however, that academic discussion and Supreme Court decisions are poor indicators of what happens at the trial court level..$^{29}$ Let us assume, therefore, that the actual significance of exclusionary rules in America diminishes as we descend from the level of the Supreme Court. Even making allowance for this, there is still ample evidence to the effect that exclusionary rules have, at least in America, a much greater practical significance than in any civil law country.

In America techniques have been developed to insulate the adjudicator of guilt from the impact of evidence adduced in litigating admissibility. ${ }^{30}$ There is concern that the adjudicator of guilt, having heard strong evidence of guilt, will be incapable of ruling impartially on the issue of exclusion, or that the adjudicator, having declared evidence inadmissible, will not be able or willing to disregard it. Consequently, for instance, preliminary hearings prior to trial on motions to suppress illegally obtained evidence are quite common in American jurisdictions, and are indicative of the practical impact of exclusionary rules. Even those in America who deplore the frequency of cases in which illegal evidence reaches the adjudicator of guilt will not dispute statistics revealing numerous cases in which incriminating evidence

importance. Thus, for example, private mail can under certain circumstances be seized and opened. See West Graman Code, supra note 5, § 99.

It must also be emphasized, however, that all continental systems provide for various safeguards against police abuse in conducting searches (e.g., two attesting witnesses). Also, certain objects seized by the police (e.g., letters) can be examined only by the investigating judge. Searches for intangibles, such as electronic surveillance, are regulated so differently in individual civil law countries that I can offer no capsule view, except to note that in every civil law jurisdiction electronic eavesdropping without a court warrant is permitted in both internal and external national security cases. On this point, again, West German law seems to be more restrictive of government authority than most continental jurisdictions. See E. KERN \& C. Roxin, STRAFVERFaHRENSRECHT 102 (1970).

29 In addition, one must not forget that where, as in the United States, most defendants plead guilty, the constitutional law on exclusionary rules is of little avail to the defendant. In keeping with limitations indicated at the outset of this essay, I shall, however, not explore the broader perspectives suggested by this point. See notes 100-01 infra \& accompanying text.

30 See Jackson v. Denno, 378 U.S. 368 (1964). Similar devices can be found also in nonjury criminal cases. See Levin \& Cohen, supra note 9 , at 918-25. 
has been ruled inadmissible with the consequent dismissal of charges. ${ }^{31}$ What happens on the Continent? Surely the structure of the continental tribunal, where lay and professional judges sit together, makes it somewhat less natural to separate issues of admissibility from issues pertaining to the merits of the case. Even so, just as in American nonjury cases, procedural devices could be developed. ${ }^{32}$ This, however, has not been the general course of development in civil law jurisdictions.

Although there are no comparative statistics on this point, I believe that I can state with a great deal of confidence that motions to exclude illegally obtained evidence are much less frequently made in continental courts than they are in America. Even where such motions are made on the Continent, the preliminary issue of whether illegalities occurred is determined in a somewhat cavalier manner by American standards. ${ }^{33}$ Small wonder, then, that cases in which exclusionary rules lead to acquittals are much more rare on the Continent than they are in America. Let us imagine for a moment that it were proposed in a typical continental jurisdiction that a hearing before another judge on the issue of admissibility be ordered whenever the latter issue arose. Serious criticism of this suggestion would probably begin with arguments centering on administrative inconvenience and on the injection into the criminal case of too many "collateral issues" which tend to overshadow the adjudication of the merits. Also, the danger of having the same person decide the question of admissibility and the ultimate issue of guilt would seem less plausible. But I believe that, if pressed far enough, continental lawyers would admit that their opposition to consistent and vigorous enforcement of the second type of exclusionary rules rested in the final analysis largely on their fears that "obviously" guilty defendants may finally have to be acquitted. ${ }^{34}$ This to them would appear intolerable. This reaction is, of course, shared by many

31 See, e.g., Oaks, Studying the Exchusionary Rule in Search and Seizure, 37 U. CसI. L. Rev. $665,743-46$ (1970).

32 Such devices might include hearings before another judge, disqualification, etc. See generally Levin \& Cohen, supra note 9.

${ }^{33}$ I submit that even those who are highly critical of American proceedings upon motions to dismiss would have to agree with my observation, which is borne out by the facts that the same trial judge or panel decides admissibility as well as guilt or innocence, and that attempts to develop techniques to insulate the trial judge from exposure to illegally obtained evidence during the pre-trial investigation are very rarely encountered. For two such attempts see FRENCE CODE, supra note 26, art. 173; YugosLAV CODE OF CrRnINAL ProcedURe, supra note 5, art. 81 (requiring that traces of illegally obtained evidence be expunged from the dossier). Finally, special rules on the burden of proof-for example, placing on the prosecution the burden of proving that a confession has not been coerced-would seem to continentals to involve too much refinement and injection of collateral technical problems into the criminal trial.

$34 \mathrm{By}$ "consistent" and "vigorous" enforcement I mean exclusion which relates not only to the illegally obtained evidence itself, but also to its fruits. Only under these circumstances can an argument be made that the exclusionary rule may serye as a deterrent to illegal practices. 
lawyers brought up in the Anglo-American legal orbit. ${ }^{35}$ Even so, I believe that a pronounced attitudinal difference remains, and that it reflects a larger contrast regarding views of restraints placed on the pursuit of truth in the criminal process. ${ }^{36}$

\section{An Overview}

At this point I should attempt to pull the threads together. How does the operation of both types of exclusionary rules affect the prosecutor's chances to obtain a conviction? If my analysis of the two types of these rules is correct, the common law of evidence presents much more formidable obstacles to introducing incriminating evidence than does the civil law governing the identical initial phase of adjudicative factfinding. ${ }^{37}$ As with American television, which has fewer lines than the European, the informational sources the common law prosecutor can use are less numerous than those of his continental colleague. But, to continue the metaphor, does the quality of the picture on the screen depend solely on the mass of relevant information? Surely not. But only the rejection of some sources of information by the common law can be explained by a desire to improve factfinding reliability. The rejection of others is clearly a conscious sacrifice of factfinding accuracy for the sake of other values.

\section{B. Presentation of Evidence}

The comparison of evidentiary burdens at the next factfinding phase is complicated by the striking contrast in the way evidence is examined in the two procedural systems. In the common law adversary procedure each party presents his case, calls his witnesses and examines them. The civil law non-adversary trial is in the nature of an official inquiry presided over by the judge: whatever evidence he decides to examine becomes his-or, rather, the court's-evidence. Accordingly, there is strictly speaking no "prosecutor's case" and there are no "witnesses for the prosecution." The bulk of questioning comes typically from the bench and it is the presiding judge who begins the examination of witnesses. ${ }^{38}$

35 For a quite striking recent example of such disenchantment, see the dissenting opinion of Chief Justice Burger in Bivens v. Six Unknown Named Agents, 403 U.S. 388, 411 (1971), and his appendix setting forth authorities in support of his position, id. at 424-27.

36 These will be traced in Part II of this essay.

87 As the careful reader must have noticed, I have excluded from the range of my discussion a number of problems with a definite bearing on the difficulties in introducing evidence. Most of these center around the so-called preliminary findings of fact (e.g., laying a foundation for the use of various evidentiary and procedural devices, proof of the chain of custody, proof of corprus delicti, etc.).

88 An exception to this rule will be found in Denmark and Sweden, but even there 
The consequences of this basic difference in the proof-taking style are legion, but I cannot delve here into all their ramifications. Only one consequence will be singled out for detailed discussion as it most directly relates to my theme; it is the absence in the structure of the continental trial of the idea that some evidence must be produced by the prosecution before the adjudicator can proceed to determine the facts of the case. The implications of this difference between the two systems will be traced in the procedural position of the defendant at trial and in the existence vel non of corroboration rules. Next, the impact of common law presumptions of guilt and restraint on evidentiary disclosure will be examined and put on the scales in weighing procedural burdens.

\section{The Defendant as an Evidentiary Source at Trial}

It is sometimes said that there is no privilege against self-incrimination in the continental system of criminal procedure. ${ }^{39}$ If, parochially oriented, we expect to find in the civil law system exactly the same procedural arrangements which in the American variant of the common law system are classified under this rubric, the above statement is obviously true. If, however, we assume that the minimum content of the privilege reduces to the idea that no person should be compelled to cause his own conviction by testifying, then the statement is generally false. Differences between the two systems appear only if we go beyond the minimum content and explore the technical implementation of the privilege, its range, and its underlying policies. ${ }^{40}$ These differences are

the judge assumes a much more active role in the proof process than is customary in common law courts. Probably following the admonition of very influential scholars, see, e.g., 2 H. ZaCHARTAE, HANDBUCH DES DEUTSCHEN STRAFProzesses 203 (Göttingen 1868), the draftsmen of the German Code of Criminal Procedure inserted in 1877 a provision providing for party examination of evidence. Although the provision remains in the Code to the present day, see WEST German Code, supra note 5, \& 239, it has never been used in practice. Cf. 2 E. SCEMMDT, supra note 15 , at 643 . Similarly, the door to party presentation is opened by art. 304 of the Japanese Code of Criminal Procedure. See S. DANDo, supra note 16, at 374. For interesting developments in Spain see G. TACKENBERG, KREUZVERHÖR UND UNTERSUCHUNGSGRUNDSATZ IM SPANISCHEN STRAFPROZESS passim (1960). The codes of criminal procedure of four constituent republics of the Soviet Union provide that the judge must examine the defendant last. See M. CHeITsov, Sovetskyi Ugorovny Protsess [Soviet Criminat Procedore] 383 (1962).

For the sake of simplicity, I am speaking here only of the interrogation of witnesses. Continental systems distinguish, however, among defendants, expert witnesses and simple witnesses for the purposes of formulating procedural and evidentiary rules concerning, for example, the manner and formalities of interrogation, duty to take an oath, and so forth. Another important difference neglected in the text concerns the continental rule of permitting all persons examined to give a narrative account first, before being subjected to questioning. This fact, coupled with the more general preference for using "spontaneous" rather than "coached" witnesses, is of relevance here, and will briefly be touched upon at the end of this study. See notes 219-20 infra.

39 Cf., e.g., Clapp, Privilege Against Self-Incrimination, 10 RUTGERS L. REv. 541, 548 (1956).

40 Perhaps a few salient differences deserve mention here. The range of the privilege, at least in its American variant, exceeds to a somewhat uncertain degree mere testimonial 
important here only insofar as they apply to the defendant's position at the trial stage.

In contrast to the common law concept of the privilege, the continental defendant is not free to decide whether to take the stand and submit to the interrogation process. Questions can always be asked of him. He only has the right to refuse to answer at all, or refuse to respond to particular questions. ${ }^{41}$ Although, as a matter of formal doctrine, the trier of fact is usually not permitted to draw unfavorable inferences from his silence, the defendant's quite realistic concern that such inferences will, consciously or unconsciously, in fact be drawn, acts in a typical case as a psychological pressure to speak and respond to questions. Thus, it should occasion no surprise that almost all continental defendants choose to testify. ${ }^{42}$ The pressure to speak is, I believe, somewhat stronger than the parallel pressure in the common law trial on the defendant to take the stand, as more immediate inferences can be drawn from refusal to answer specific questions than from the general refusal to submit to the questioning process. ${ }^{43}$ Responding to

evidence, while it is strictly limited to verbal utterances on the Continent. Thus, for instance, in America the privilege is said to bar forced production of the defendant's records, while in civil law jurisdictions such production has no connection whatsoever with the privilege, and is in principle permissible. It is also possible that the "communicative" types of evidence, to which the principle applies in America, see, e.g., Schmerber v. California, 384 U.S. 757, 760-65 (1966), are more inclusive than those governed by the continental privilege. A thornier question is whether continental jurisdictions would go as far as American law in construing what shall be classified as "coerced" testimony. Can, for example, depositions be used in a continental criminal case which were obtained earlier, in the course of an independent investigation of police corruption, from a police officer who was warned that his failure to answer may lead to removal from his position, as was the case in Garrity v. New Jersey, 385 U.S. 493 (1967)? I believe that most civil law jurisdictions would answer in the affirmative. See in this connection the interesting disciplinary case in which the Court of Justice of the European Communities drew unfavorable inferences from the defendant's refusal to testify on a crucial point: Alvis v. Conseil de la C.E.E., 9 Recueil de la Jurisprudence de la Cour de Justice des Communautés Européennes 99, 116 (1963). Finally, as noted before, the privilege as applied to witnesses is in some civil law jurisdictions construed very broadly. See note 24 supra. It covers not only "self-incrimination" but also incrimination of close relatives. There is also no possibility on the Continent to remove the privilege of a witness by granting him immunity.

41 This right of silence is of a relatively recent vintage on the Continent. The medieval inquisitorial procedure not only required that the defendant testify, but also permitted enforcement of this duty through torture. After the use of torture was outlawed toward the end of the 18th century, most continental procedural systems still provided that the defendant had the "duty to answer" and even threatened punishments (poenae inobedientia) for failure to obey it. See, e.g., E. ScmMnd, EINFüHRUNG IN DIE GESCHCHTE DER DEUTSCHEN STRAFRECHTSPFLEGE 271 (3d ed. 1965). Surprisingly enough, some vestiges of this view still survive in continental procedural law. See, e.g., H. PFENININGER, Die Wahrheitspflicht des Beschuldigten im schweitzerischen Strafverfahren, in Probleate des SCHWEIZERISChen StrafprozessRechts 116-20 (K. Bader ed. 1966).

42 Refusals to answer any questions at all are mostly encountered in political trials where such an attitude may be interpreted as defiance of the court and as a political protest.

43 As indicated earlier, the overwhelming majority of continental defendants choose to answer most questions. But even if they refuse to say anything, many systems would still permit the judges to address specific questions to them. The view expressed in the text seems to be shared by Glanville Williams. See G. Writiams, supra note 22, at 63 . 
these pressures, the guilty defendant will often resort to lies in order to escape conviction. Nevertheless, recognizing and tolerating this frequently instinctive desire of the guilty defendant to play the innocent, modern continental systems generally refuse to put the defendant on oath. Nor do any adverse legal consequences befall the defendant if the falsity of his testimony is established at trial, ${ }^{44}$ though he will, of course, hurt his credibility as an evidentiary source. It appears, then, that the continental system is not concerned about exposing the trier of fact to the defendant's unsworn testimony, although-considered as a class-it is of dubious trustworthiness. It is believed that precious information can be obtained even from false denials of guilt, detected inconsistencies, and other verbal or non-verbal expressions emanating from the defendant's person. All this information enters into the totality of data on the basis of which guilt-determination will eventually be made.

So much for the preliminary juxtaposition of the "right not to be questioned" and the "right not to answer questions" at trial. The proper dimensions of the difference in the approach of the two systems to the use of the defendant's testimony at trial can, however, not be ascertained if one ignores the time sequence. In the common law trial, of course, the defendant cannot take the stand, even if he wishes to do so, before the prosecution has established a prima facie case. Before he is given a chance to submit to questioning, he has already heard the witnesses for the prosecution. Consider the defendant's position in the continental courtroom. As there is no requirement here that the prosecution establish a credible case before the defense introduces its evidence, there is no obstacle to beginning the proof-taking stage by the interrogation of the defendant, and this in fact is the rule in con-

44 The fact that no adverse legal consequences befall the defendant even if the falsity of his testimony is discovered has led some continental scholars to postulate that the defendant has a "right to lie." This is, at the least, analytically fallacious. Cf. 1 G. Foscemina, Sistema ded Diritto Processuale Penale 437 (1965); H. Pfenninger, supra note 41 , at $105 ; 2$ E. ScEMTDT, supra note 15 , commentary to $\$ 136$ nos. 11, 13, 15.

More importantly, the theoretical construct of the "right to lie" glosses over the fact that, as a practical matter, detected inconsistencies or outright lies in the defendant's testimony will be assessed against him by the factfinder. The defendant will diminish his credibility as a source of information favorable to his case, and his denials will lose their probative value.

Furthermore, the defendant's lies and "persistent" false denials usually affect the sentence. In some European jurisdictions it is a common, although not universally accepted, practice to consider detected lies as an aggravating circumstance. For example, see the West German practice described in H. BRUNS, STRAFzUMressungsRechi: AurgeMIEINER TEII 526 (1967). Compare also the prosecutor's closing argument in S. BEDFORD, supra note 17, at 177. True, the doctrine in a number of civilian jurisdictions declares that false denials should not be considered an aggravating circumstance, but the doctrine is difficult to reconcile with the almost universally accepted practice of treating confessions of guilt as a mitigating factor. The more we proceed along this line of analysis, the more the notion of a "right to lie" appears Pickwickian. It may more meaningfully be said that the defendant's lies are tolerated by the criminal justice system. 
tinental systems. ${ }^{45}$ True, the continental legal folklore tells us that the defendant's interrogation comes first because it is primarily a means accorded him to contest the prosecutor's charges. ${ }^{46}$ But, whatever the proclaimed rationale, the fact still remains that in all continental systems the defendant is used as an evidentiary source before any other evidence has been examined at the trial. ${ }^{47}$ While the strategic value of this arrangement for the defense is a matter of some dispute, there is little doubt that it is advantageous to the prosecution..$^{48}$ At the begin-

45 The only system on the Continent under which there was no interrogation of the defendant at trial before incriminating evidence raised the need for some kind of defense was that of the Russian Tsarist Criminal Procedural Code, provided that the defendant declared himself not guilty. The defendant was examined first only if at the beginning of the trial he chose to confess. See Fonmitsky, Kurs Ugolovinago SUdopriozstva [A Course in Cramonat Procedure Before the Courts] 361 (2d ed. 1899). On the legislative history of this procedural arrangement see I. SCHCHEGLOVITOV, UsTAV UGOlovnago Sudoproizvodstva po Prodolzhentu [Code of Crimtinal Procedure] 528 (1913).

Distantly echoing this procedural arrangement, existing Soviet law is quite flexible in its provisions regarding the order of examining defendants and witnesses. Although the defendant's interrogation will usually precede the hearing of witnesses, judges may decide to hear witnesses first, in order to show to the defendant "the pointlessness" of his persistent denials. See M. CereLtsov, supra note 38, at 382.

48 The folklore is reflected in legal semantics. The term "interrogation" is sometimes replaced by expressions which connote that the judge passively listens to the defendant's narrative. Another amusing example of downgrading the evidentiary aspects of the defendant's interrogation is to regulate it outside of code provisions on the reception of evidence. Thus, WEST German Code, supra note 5, art. 244(I) provides that "the reception of the evidence follows the examination of the defendant." For a realistic assessment of the actual meaning of the defendant's interrogation, see Dominioni, Imputato, in 20 Enciclopedia DEI DIRTTTo 789, 813-15 (1970); Bayer, La Signification de L'Aveu de L'Inculpé dans le Droit de Procédure Pénale de Certains Etats Occidentaux Européens, 2 (N.S.) Rivista Italiana di Diritto e Procedura Penale 724 (1959).

47 Someone might say at this point that a strong case has already been established prior to trial, in the course of the preliminary investigation, and that there is consequently no need for the prosecution to establish a prima facie case at trial. However, according to the continental legal folklore, the "veil of the dossier" must be lifted from the trial in keeping with the principle of immediacy, and factfinding proceed afresh. See note 15 supra. Accordingly, pursuant to the folklore's logic, evidence adduced before trial is without weight, so that the defendant is indeed interrogated before any technical evidence is in. In actual practice, the presiding judge will, in most jurisdictions, have studied the dossier and familiarized himself with this continental variation on the theme of prima facie proof. However, the fact still remains that the defendant is examined by the judge before any other evidence has been heard directly by him, or in any way by other members of the panel.

48 Glanville Williams suggests that the continental practice of examining the defendant first has a "distinct" advantage of giving him the chance to make the "first impression" on the factfinder. G. WIrtuars, supra note 22 , at $81-82$. He seems to have some support among behavioral scientists. For instance, F. LUND, EMrotions of MEN 38-41 (1930), argued that there is a "law of primacy" in persuasion. A person exposed to adversary argumentation forms his opinion on the basis of the first argument and this opinion cannot be easily dislodged. For an empirical study indicating that the party who goes second in proceedings has the advantage, see Walker, Thibaut \& Andreoli, Order of Presentation at Trial, 82 YaIE L.J. 216 (1972). It is submitted, with deference, that the defendant's alleged advantage pales to insignificance when assessed against the disadvantage of having to argue before knowing how the prosecution's case will develop. Also, the first thesis, in a sense, is actually that of the prosecution, contained in the indictment which in continental courtrooms is read out along with detailed supporting grounds. If one adds to it the possibility that the defendant's argument may be poor and unconvincing and that he may entangle himself in contradictions, one will probably be led to the belief that the defendant's "advantage" is a kind of privilegium odiosum. For 
ning of the case the prosecutor may sit back and expect that leads or evidence damaging to the defendant will come out of his interrogation. Also, the prosecutor may hope that the concocted story of a guilty defendant will crumble in the light of testimony of subsequent witnesses. In contrast, the prosecutor in the common law system must, before he can hope to obtain incriminating evidence through the trial interrogation process of the defendant, come forward with substantive proof of guilt by using items of evidence other than the defendant's statements in court. $^{49}$

\section{Operation of Corroboration Rules}

The operation of the so-called corroboration rules of evidence in the common law system creates another possible barrier to conviction which continental prosecutors have never encountered. Of course, the term "corroboration" has many meanings and denotes various evidentiary devices. Some of these affect the admission of evidence, while others bear on its final weighing. ${ }^{50}$ What concerns us here are only those rules of corroboration which prevent the prosecution from even reaching the factfinder on a given point unless the required additional piece of corroborating evidence has been produced. Such rules are numerous and their impact of great practical importance in many cases. For instance, the testimony of a rape victim will, in many American jurisdictions, if not corroborated by other evidence, not even be given to the trier of facts to evaluate. In other words, the prosecution will fail to establish a prima facie case of rape.

Again, the contrast with the situation on the Continent is striking. Not only is there no requirement for the prosecution to make out a prima facie case, but there are also no evidentiary rules requiring that a certain proposition of fact necessary for the ascertainment of guilt be proved by more than one piece of evidence. Such rules would signify

a somewhat similar argument to that developed here see P. Bouzat \& J. PINater, supra note 13 , at 1072 .

On the other hand, it cannot be denied that the defendant's disadvantage is lessened to some extent by his familiarity with the dossier. However, because the dossier contains only summaries of testimony, the defendant cannot fully anticipate the actual impact the testimony of any witness may have at trial, and this compensating privilege to examine the dossier is not as valuable as it might initially appear.

49 This does not mean, of course, that the common law prosecutor will always use evidentiary material emanating exclusively from sources independent of the defendant's verbal utterances. As noted before, admissibility rules and the prima facie hurdle will make the use of out-of-court admissions and confessions frequently even more precious to a common law prosecutor than they are to his continental counterpart. See note 23 supra. This instance of repressed needs for efficiency in prosecuting which assert themselves in less direct ways will be taken up later. See note 100 infra.

50 Some others amount to the judge telling the jury that they may convict on uncorroborated evidence only if convinced of its truth. Essentially, they reduce to permissible negative comments of the judge on the weight of evidence. $C f$. G. Wricrams, supra note 22 , at $170-71$. 
to continental lawyers a partial return to the system of legal proof which has been a bette noire since the middle of the eighteenth century..$^{11}$

\section{Counterbalancing Factors}

\section{a. Prima Facie Presumptions of Guilt}

Difficulties associated with the prosecutor's burden of establishing a prima facie case should be borne in mind when assessing, within the framework of a comparative study, the role of those guilt presumptions which affect solely the burden of producing evidence, leaving the burden of persuasion on the prosecution. This is, I believe, the actual effect only of those presumptions which "drop out of the case" after some adverse evidence has been adduced by the defendant, so that the case is submitted to the factfinder as if no presumption ever existed. ${ }^{52}$

What is the real effect of such guilt presumptions? They aid the common law prosecutor in reaching the trier of fact on a factual issue, and frequently put some pressure on the defendant to take the stand and testify, although the prosecutor has presented relatively little evidence of guilt. Obviously, then, such presumptions counterbalance prosecutorial difficulties which do not exist in the civil law system. As there is on the Continent nothing comparable to be counteracted, it should come as no surprise that presumptions have no real counterpart in continental evidentiary law. ${ }^{53}$

61 Corroboration rules would be termed by continental scholars negative, as opposed to positive, rules of legal proof. While the latter require conviction where certain kinds of evidence are gathered, irrespective of the subjective evaluation of factinders, see note 10 supra, the former require the factfinders not to convict, irrespective of their convictions, before certain kinds of evidence are gathered. While the negative rules of legal proof leave somewhat more leeway to the subjective evaluation of evidence by the factfinder, they still violate the revered continental principle of "free evaluation of evidence."

Whether all vestiges of the negative rules of legal proof have disappeared from continental law is, however, not altogether clear. It is, for instance, a hotly debated issue whether a judgment of conviction can rest solely on the defendant's confession, although the judge is thoroughly convinced of its verity. In practice, of course, at least a modicum of corroboration is always found. Also unclear is the status of sporadic rules requiring the judge to call in an expert irrespective of whether other evidence has persuaded the judge concerning a specific proposition of fact.

52 These, to Thayer, were genuine presumptions. See J. Thayer, A Prertamnary Treatse on Evidence aT the Comaron Law 337 (1898). Why my discussion is limited for the moment to this narrow class of guilt-presumptions will be explained below. See text accompanying notes 54-55 infra.

53 Probably the nearest continental analogue to prima facie presumptions is the theoretical construct of "factual presumptions" (presumptiones hominis seu facti) or provisional (interim) facts. However, those who hold that these constructs are applicable to criminal cases-and there is no unity on this issue-include only one such presumption relating to the defendant's guilt: the presumption of the defendant's sanity. Let us sketch in a few strokes how the working of this presumption is explained by continental lawyers. The latter view the defendant's sanity as his mental capacity for blame and thus a necessary prerequisite to a finding of guilt and criminal conviction. Strict logic would, then, require an explicit finding of sanity before conviction in each and every criminal case. In fact, sanity will not be subject to proof in every case, but only in cases where 
How does this difference affect the comparison of prosecutorial evidentiary burdens? As I see it, such "prima facie" presumptions at best decrease the burden of the common law prosecutor to a level comparable to evidentiary burdens of his continental colleague. Only where they operate can an argument be made that prosecutorial diffculties in presenting evidence are not significantly different under the two procedural systems.

As the initiated know, many other so-called "prima facie" presumptions exert their influence beyond the level of allowing the prosecutor's case to reach the jury. Whenever the jury is instructed on such guilt presumptions, even if told that the persuasive burden remains on the prosecution, its effect spills over and influences the jury in their evaluation of evidence. If told by the judge that the law considers the finding of one fact strong, though only "prima facie," evidence of another fact, the jury will in most instances probably be impressed by such favorable comment on the inferential value of a fact they have determined. ${ }^{54}$ It would be unrealistic to ignore this spillover effect. However, comparative analysis of this additional effect of presumptions must temporarily be postponed. It is only on the next factfinding level, that of weighing and evaluating evidence, that I shall return to guilt presumptions. ${ }^{.5}$

doubts arise concerning the defendant's sanity. This leads the continental scholars to speak of the presumption of sanity.

That sanity must be proven only if there is some indication contra, appears to some scholars to be the result of the operation of a presumption of sanity. Put differently, the natural course of events is said to warrant a provisional (or interim) finding of sanity. What happens if there is some evidence tending to indicate insanity? The presumption (or interim fact) "drops out of the case," in the sense that it does not affect ultimate factfinding. If the proof of mental capacity is inconclusive, insanity rather than sanity will be assumed in most civilian jurisdictions, even though the presumption of sanity was not rebutted. But this is as close as this sole continental factual presumption relating to guilt comes to Thayerian prima facie presumptions. What are the differences? The continental defendant is not required to come forward with one iota of evidence to rebut the presumption; it suffices that some doubt arise in the context of the case, say, from a remark of a witness offered by the prosecution. Moreover, the purpose of the continental presumption of sanity, unlike Thayerian prima facie presumptions, is not to help the prosecution to reach the trier of fact, simply because there is no problem in reaching him at all. Finally, the issue of the defendant's mental capacity for guilt must, when warranted, be explored by the court of its own motion. It is the court's official duty to establish all guilt-prerequisites, so that the imposition of criminal sanctions may be justified.

For another rough analogue, the German "Schutzbehauptungen," see E. DöERING,

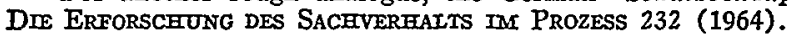

In America, the draftsmen of the Model Penal Code refused to grant the judge authority to raise the defense of insanity sua sponte on the ground that it would constitute "too great an interference with the conduct of the defense." MODEL PENaI CODE § 4.03, Comment at 194 (Tent. Draft No. 4, 1955). Even so, some American jurisdictions, such as the District of Columbia, authorize the trial judge to raise the issue of insanity motu proprio. See, e.g., Whalem v. United States, 346 F.2d 812, 819 (D.C. Cir. 1965).

54 See the perceptive analysis in Ashford \& Risinger, Presumptions, Assimpiions, and Due Process in Criminal Cases: A Theoretical Overviev, 79 YaLE L.J. 165, 199 (1969).

55 The following argument may be anticipated here. The common law defendant will often be saddled with the burden of coming forward with some evidence when facts 


\section{b. Disclosure of Evidence Compared}

In weighing prosecutorial burdens at the level of producing evidence, there is yet another aspect which deserves discussion. It is the problem of whether evidence intended for use at the trial has to be disclosed to the parties. As noted before, the continental trial is preceded by an investigation whose purpose is not only to screen unfounded charges, but also to prepare evidentiary material for examination by the court. The extent to which the defendant is entitled during this investigation to acquaint himself with evidentiary material (for example, by studying the dossier or participating at proof-taking activities) is differently regulated from jurisdiction to jurisdiction. ${ }^{5 B}$ But, even in those continental countries which are most restrictive in this regard, the defendant and his counsel acquire, before the case comes up for trial, an unlimited right to inspect the whole investigative dossier. As the latter must contain summaries of all testimony and records of all proof-taking activity, the defendant can familiarize him-

constitutive of affirmative defenses are in issue. As will appear later, see note 93 infra \& accompanying text, the idea of affirmative defenses is alien to continental criminal law. According to prevailing continental doctrine, the defendant has no burden of coming forward with evidence when facts are in issue which would be classified by common law lawyers as affirmative defenses. Thus, a large difference relevant to comparative prosecutorial burdens of establishing guilt seems to exist on this score.

I believe that the contrast looms large only if we remain on the level of studying continental doctrine rather than actual practice. In most instances the continental defendant will, for strategic reasons, willingly assume the burden (Darlegungslast) of what the Germans call "Schutzbehauptungen." See E. DögRnNG, supra note 53, at 232. He will, in other words, not remain passive, but testify to facts coterminous with facts constitutive of affirmative defenses. Considering the fact that the common law defendant's burden is usually sustained by the defendant taking the stand to testify on "affirmative defenses," the practical impact of the doctrinal difference is not hard to assess. In a typical case, whatever burden is placed on the common law defendant to come forward with some evidence on a defensive issue is only a part of the burden placed on the continental defendant earlier, in a system where the trial begins with his interrogation on all issues. There is, however, the possibility of a residual difference here. A case may arise where evidence in support of facts classified in the common law system as elements of a defense enters the case independent of the defendant's testimony, for example, by way of a remark of a witness offered by the prosecution. Even if the defendant remains totally passive in such a case-which would be rare indeed - the continental court will have to explore the "defensive issue" as part of its official duties.

My view that practical differences are not very significant on this score is shared by Jescheck, Principles of German Criminal Procedure in Comparison with American Law, 56 VA. I. REV. 239, 247 (1970).

$56 \mathrm{~A}$ caveat seems appropriate here. The realistic assessment of the practical impact of some very liberal continental provisions always requires that we explore whether or not the bulk of investigative activities has shifted from the formal judicial or prosecutorial investigative stage to the often informal administrative police inquiry. If this transition has in fact taken place, and decisive incriminating evidence gathered, broad procedural safeguards during the formal investigation, such as inquiring whether the defendant desires counsel, may well be of little practical value to him. They are, to borrow a phrase from Chairman Mao, like a comb given to us only after we have become bald. Perhaps the best known example of such a shift in emphasis from a very formal investigation with liberal safeguards to a rather informal, low-visibility inquiry is the shift from the former French instruction préparatoire to the enquête officieuse. See $\mathrm{R}$. Voudn \& J. Líauté, Droit Pénal ex Procédure Pénale 255-56 (3d ed. 1969); 2 G. STEFANI \& G. LEVASSEUR, supra note 5, at 215. 
self in this fashion with all evidence previously collected. The prosecutor's charge sheet, framed on the basis of the investigation, must indicate in considerable detail what the prosecution's legal theories are and what evidence will be offered to the court. True, both parties may introduce additional evidence at trial, but whenever there is surprise and one party is unprepared to counter new evidence, the court will as a rule grant a continuance. ${ }^{57}$ The practice of trying to spring a surprise by the late introduction of evidence will be frowned upon by the judges for a variety of reasons I cannot even begin to enumerate here. However, although the continental judge may reject proof offers by the parties, he cannot "punish" a party by refusing to hear a surprise witness. Such a ruling would be thought to violate the judge's duty to ascertain the truth. In sum, there is full advance disclosure of issues and evidence, and, in general, neither party can expect to score points by the unexpected introduction of new evidence..$^{58}$

- Some common law jurisdictions have of late adopted a type of preliminary hearing which leads to a great deal of evidentiary disclosure. ${ }^{59}$ The contrast between this system and the continental one is not negligible but cannot be traced here. Instead, let me focus the discussion on the contrast between American and continental attitudes toward disclosure, for it is here that we find important differences for the purpose of studying evidentiary burdens. The so-called "discovery" rules differ to a great extent in American jurisdictions, but even under the most liberal ones the defendant is not entitled to learn the substance of what the witnesses for the prosecution have to say. ${ }^{60}$ Moreover, often he will be left guessing as to who will appear in court as a witness for the prosecution.

How does this difference affect our comparative analysis of prosecutorial difficulties in obtaining a conviction? It is not difficult to conclude that restraints placed on disclosure make it harder for the American defendant to rebut the prosecutor's evidence, thus indirectly decreasing prosecutorial evidentiary burdens. True, this conclusion may be countered by claiming that surprise may upset the prosecution too, and that both parties are equally affected by lack of disclosure. It seems, however, that the prosecutor is more favored than the defendant by lack of full discovery, and that the "balance of advantages"

57 See, e.g., West German Code, supra note 5, § 246(II).

58 Of course, there will always be room for some surprise at trial. The impact of testimony in response to a new question, deviations from prior testimony, as well as many other factors may not be predicted through familiarity with the dossier. (1970).

59 See Norton, Discovery in the Criminal Process, 61 J. CrIM. L.C. \& P.S. 11, 12-17

60 Compare the comparative discussion of discovery rules in American and continental civil proceedings in R. Schlesinger, CoMararative Law 304-07 (3rd ed. 1970). 
is tipped on this score in the direction of the prosecution. ${ }^{61}$ It must, therefore, be conceded that American discovery rules create the second counter tendency which reduces the comparatively greater burden the American prosecutor sustains in producing evidence. Is this countertendency so strong as to reduce to insignificance whatever differential burden the two styles of producing evidence place on prosecutors?

Here one must bear in mind that there is, from the American perspective, a price the continental defendant pays for full familiarity with incriminating evidence in advance of his trial. In discussing the different concepts of the privilege against self-incrimination, I remarked that the continental defendant is more readily subjected to the interrogation process than his common law counterpart, and more easily available as an evidentiary source. In a typical case the pre-trial dossier will "discover" to the prosecutor much of what the defendant will later testify at trial. It is very unusual indeed for the defendant to hold back information at the investigative stage and surprise the prosecution by testifying at the trial. It would be less atypical if the defendant revealed less at trial than in the course of the investigative stage. In addition, the defendant's documents, including such items as private letters and possibly even diaries, ${ }^{62}$ will be forcibly produced and included in the file of the case. As a result, the dossier will disclose all the incriminating evidence and exculpating evidence, much beyond the limits dictated by American views on the privilege against selfincrimination. Thus, continental disclosure is more of a two-way street than it can be, consistent with constitutional requirements, in America. Nor is this all. As noted before, ${ }^{63}$ evidence contained in the dossier is in a sense "canned" for subsequent use at trial, and the argument common in America that discovery may lead to opportunities for tampering with evidence is just not given credence in the context of continental procedure.

The price the continental defendant pays for full disclosure ${ }^{64}$ obviously reduces the demands which the proof-taking phase of the

61 See Goldstein, The State and the Accused: Balance of Advantage in Criminal Procedure, 69 YALE L.J. 1149, 1180-92 (1960); Norton, supra note 59, at 13-14.

62 See note 28 supra. In the case of diaries, only a very limited number of civilian jurisdictions place restrictions on their use as evidence. For example, see the famous West German "diary case," 19 BGHSt 325. For an excellent discussion of this case see E. KERN \& C. Roxin, supra note 28, at 102. Compare the continental approach to that expressed in Boyd v. United States, 116 U.S. 616 (1886), which still seems to be good authority.

63 See note 19 supra.

64 Perhaps I should indicate here that the problem of disclosure does not present itself to continental lawyers as one of balancing advantages. Full advance disclosure is simply viewed as one of the postulates of rational factfinding. The relationship of discovery to broader problems of procedural models will be touched on briefly in the second part of this Article. 
trial places on the continental prosecutor. If, then, the advantages the American prosecutor gains through lack of full disclosure are considered against the background of the total discrepancies which exist between the burdens of continental and common law prosecutors, it seems fair to conclude that, despite the offsetting effect of these advantages, some disparity of burdens still remains. The continental prosecutor seems to me to have less difficulty in connection with production of evidence, although not nearly as much less as might appear in light of the fact that he does not have to make a prima facie case at trial.

\section{Weighing of Evidence}

I now turn to the final phase of the proof process, in which factfinders weigh evidence and arrive at the decision, the common law jury in the privacy of their jury room, and the continental mixed panel $^{65}$ in the secrecy of the judge's chamber. I cannot explore here many fascinating problems involved in contrasting the functioning of these two different decisionmaking bodies. ${ }^{68}$ What is immediately material here is the question whether the prosecutor will find one of these two bodies harder to persuade of the defendant's guilt.

\section{Different Rules Governing Voting}

The common law verdict of guilty was traditionally required to be unanimous. Of late this rule seems to be in eclipse, but is, despite some quite recent ominous signs, still retained in the majority of

65 I am limiting my discussion in the text to the mixed panel because it is the most representative continental adjudicator. The jury trial has been retained only in a small number of countries, modified and restricted to the trial of a narrow class of criminal offenses. See note 4 supra. Where cases are tried to professional judges only-and this is the case in most continental countries for less serious offenses and in the Netherlands for all offenses - my arguments in the text will apply a fortiori. Perhaps the reader should also be reminded that the continental mixed panel decides in a single deliberative session both on the issue of guilt and on the sentence. The continental trial is not bifurcated into the guilt-determinative and sentencing stage, as is the case in America.

66 One aperçu related to my theme deserves mention here. In both evidentiary systems, each constituent element of the crime must be proven. Of course, in both systems evidence will be produced concerning only some elements, and the factfinders will be expected to draw inferences therefrom of other facts. Yet a difference seems to me to exist here, based on the impact of jury instructions on the one hand and continental "free evaluation of evidence" on the other. Continental factfinders place, I believe, more emphasis on the "Gestalt" of the proof offered and even matters not formally urged as proof. The common law jury seems more inclined to "Balkanize" the factfinding process. More individual consideration seems to be given to each element of evidence per se, following suggestions derived from the judge's instructions regarding presumptions, his appeals to disregard substantive use of evidence such as prior conflicting statements, and so forth. While it is true that instructions to the jury to ignore certain evidentiary sources, or not to use them for certain purposes, are for the most part more honored in breach than observance, it would be hasty in comparative analysis to dismiss their effect altogether. Although formal continental doctrine sometimes requires that factfinders disregard certain cognitive data (e.g., inferences from refusal to answer certain questions, or the impact of illegally obtained evidence), it should be recalled that no formal instructions to lay members of the mixed panel are required by law. 
American jurisdictions. ${ }^{67}$ Continental systems never viewed the unanimity rule with favor. Even the French revolutionaries, who in 1791 were so enchanted by English institutions that they attempted a wholesale transplantation of English criminal procedure, never went so far as to require unanimous guilty verdicts from their juries. ${ }^{68}$ Continental adjudicators decide by a majority vote, often a bare majority. ${ }^{69}$ Rare indeed are voices claiming that the continental analogue of the requirement of proof of guilt beyond a reasonable doubt presupposes a voting régime whereby the prosecutor must overcome "reasonable doubts" of all adjudicators. ${ }^{70}$

The implications of these different approaches to decisionmaking are obvious. The prosecutor will surely find it more difficult to obtain a conviction under the régime of unanimity than that of majority. For if only one juror refuses to convict, say, because of sympathy for the defendant, or because of very stringent views on sufficiency of the evidence presented, there will be no conviction. Consequently, where in the Anglo-American orbit the unanimity rule still prevails, the prosecutor can expect a less favorable "conviction-acquittal ratio."

67 For centuries Scotland has required only a bare majority, and in addition permits the "not proven" verdict. See I. WHLOCE, THE ORIGINS AND DEVELOPAIENT OF THE JURY IN SCOTLAND (1966). England abolished the unanimity rule in 1967, allowing the jury to convict by a 10-2 majority. Criminal Justice Act 1967, § 13. The "ominous signs" referred to in the text are two recent United States Supreme Court decisions in which jury unanimity was held not to be constitutionally mandated: Apodaca v. Oregon, 406 U.S. 404 (1972), and Johnson v. Louisiana, 406 U.S. 356 (1972). It is quite possible that these decisions may turn out to have been the requiem for the unanimity rule in America, as many states could well move to discard it.

68 See Statute of Sept. 16, 1791, pt. II, tit. VII, art. XXVII, 4 Lois et Actes du Gouvernement [L.A.G.] 267 (1808) (three dissenting votes block conviction). See also Constitution of Sept. 3, 1791, ch. V, art. IX, 4 L.A.G. 222 (1808) (juries must have at least $t$ welve members).

69 A special majority is required, for example, in West Germany, West Geraran Code, supra note 5, \$263 (two thirds), and in France, FRENCH CoDE, supra note 26, arts. 296,359 (eight of nine jurors). The requirement of a bare majority seems to prevail in Eastern Europe. Of interest is the Swedish system, which places considerable weight on the vote of the professional judge: the opinion of the lay assessors will not prevail over the contrary view of the professional judge unless all (or, in some cases, nearly all) lay assessors agree. See THE SWEDISH CODE OF JuDICIAT PROCEDURE ch. 29, \& 3 (The American Series of Foreign Penal Codes, No. 15, A. Bruzelius \& R. Ginsburg transl. 1968) [hereinafter cited as SWEDISH CODE].

70 For an isolated doctrinal view in this sense, see LöHSING \& SERINI, ÖESTERREICHISCEES STRAFPROZESSRECHT 99 (1952). Although, historically, the requirement of unanimity had nothing to do with the reasonable doubt standard, common law lawyers frequently link the two. See, e.g., Hall, The Rights of the Accused in Criminal Cases, in TALES ON AMIERICAN Law 55, 64 (H. Berman ed. 1961). See also the dissent of Justice Marshall in Johnson v. Louisiana, 406 U.S. 356, 399 (1972), and the more cautious dissenting opinion of Justice Douglas, id. at 381.

71 Cf. Johnson v. Louisiana, 406 U.S. 356, 381 (1972) (Douglas, J., dissenting).

It is interesting to note in passing that comparative research lends some support to the contention of the dissenters in Johnson and Apodaca that the rejection of the unanimity rule will drastically shorten deliberation. The deliberation of a continental mixed panel is relatively short, and few disagreements of a lone dissenter are maintained to the final vote. For empirical data on trials in West Germany, see Casper \& Zeisel, supra note 23 , at 151 . 


\section{Professional and Lay Propensities to Convict}

Since the common law unanimity rule seems to be diminishing in significance, another contrast between the two systems assumes greater importance. In a jury trial the determination of guilt is made solely by lay people, whereas in the continental mixed tribunal professional judges play an active role. If lay people tend to be on average more lenient in criminal adjudication than professional adjudicators, the jury will be more reluctant to convict than the mixed tribunal, and the prosecutor trying to persuade the jury of the defendant's guilt will have a somewhat harder task before him.

That lay adjudicators are, on the whole, more lenient, seems to be an impression so widely shared that it has almost become a truism. There is empirical evidence in support of these impressions, although perhaps not enough to remove the issue entirely from the realm of speculation. Disagreements between lay and professional judges have been studied, both in America and in Europe, and the results seem to indicate that in these disagreements lay judges seem on the average to favor the defendant. ${ }^{72}$ Moreover-and this is of particular importance to our subsequent discussion-there is some indication in these empirical studies that those disagreements may not be entirely accounted for by such reasons as sympathy for the defendant's plight, but also, to an extent, by "higher thresholds of reasonable doubt" on the part of laymen. ${ }^{73}$ Lay people seem often to require more evidence to convict than professional adjudicators, particularly in those cases where the decision turns on mere circumstantial evidence.

Why should lay adjudicators tend on average to be more lenient? I believe that we are presented here with only an instance of a larger phenomenon observable in other areas. Max Weber has analyzed it in talking about bureaucratization; sometimes it is discussed in connec-

72 Kalven and Zeisel have studied disagreements between the American judge and jury on the issue of guilt and found the jury to be more lenient. H. KaLVEN \& H. ZEISEL, The AMrertcan JuRY 58 (1966). Recently Casper and Zeisel have suggested the same tendency, although with a relatively small sample and much less pronounced, in disagreements between West German professional judges and lay assessors sitting together on a mixed panel. Casper \& Zeisel, supra note 23 , at 154-60, 175. In drawing conclusions from the work of Casper and Zeisel one must not lose sight of a subtle factor on which it is easy to speculate but hard to acquire empirical data. Since the continental judge is a towering figure, see note 77 infra, it is quite possible that the small number of instances in which judges noted initial disagreement with their lay colleagues $(6 \%)$ reflects the reluctance of the latter to oppose the professional judge in the first instance. For additional information on diverging lay and professional attitudes toward conviction in civil law jurisdictions see H. KALVEN \& H. ZEISEL, supra, 516-20, and Mannheim, supra note 4 , at $103,404$.

73 See H. Katven \& H. Zersex, supra note 72, at 182-90. Criticism of this admirable study has perhaps detracted from the strength of some of its findings, but does not question its conclusion that judge and jury apply somewhat different standards of reasonable doubt. See, e.g., Walsh, Book Review, 79 YaLE I.J. 153 (1969). 
tion with professionalization, but it is also an aspect of any routinization of activity. ${ }^{74}$ In all these processes what is acquired is an ever increasing measure of self-confidence, coupled with rational detachment and matter-of-factness. So, just as in other human activities, prolonged exposure to criminal litigation will result in a degree of case-hardening. Experienced professional judges will tell us about the agony they went through before convicting their first defendant on circumstantial evidence; cognoscenti might perhaps tell us that even jurors find it easier to convict toward the end of their term. The longer one is involved in the business of adjudicating criminal cases, the more these cases become depersonalized, mere representatives of general classes. Gradually the morning freshness of perceiving each case as a unique human drama is gone, and one becomes adjusted to the efficient performance of a routine task. This, perhaps, is the unfortunate "défaut de qualite" of any professionalization.

Assume that there is truth in these widely shared observations. It can then be demonstrated that the civil law system exhibits counterpressures to neutralize, when necessary, the differential lay predispositions in the adjudication of guilt.

Whatever influence the common law judge has on the jury is limited mostly to instructions. The jury sits alone and decides independently. What evidentiary evaluation leads to a verdict remains unknown because the jurors are not required to justify factual findings. In addition, the absence of appeals from acquittals in the overwhelming majority of common law jurisdictions removes another means of professional supervision of the jury. ${ }^{75}$ By contrast, the lay element on the continental panel is much more effectively controlled by professionals. The professional judge or judges retire with the lay judges, participate in the deliberation process and preside over the debate. True, the lay assessors on the bench are more often than not in the majority. Further, in most jurisdictions lay judges do play an active role and are not members of the panel for mere cosmetic purposes. Yet, few would deny that the professional judge is a towering and influential figure in the eyes of his lay colleagues. ${ }^{76}$ There is typically

74 M. Weber, From Max Weber: Essays In Sociologx 50, 54, 216-21 (H. Gerth \& C. Mills transl. 1958).

75 It is true that the absence of rational supervision goes in some instances against the defendant, such as in verdicts influenced by bias or racial prejudice; but, on balance, sympathy rather than antipathy toward the defendant seems to be the more frequent operating force.

70 This has recently been substantiated by empirical research. Casper and Zeisel studied the rate at which initial disagreement on the issue of guilt between lay and professional judges on the West German mixed panel is overcome, and discovered that in about $70 \%$ of all cases lay judges surrender their initial dissenting position. Casper \& Zeisel, supra note 23 , at 186. Cf. Zawadzki \& Kubicki, L'elément populaire et le juge pro- 
also an appeal from factual findings, and the court must state in the judgment why it gave credence to one item of evidence rather than another. ${ }^{77}$ The prosecutor thus knows that even if he fails to obtain a conviction on strong evidence from the original adjudicator, he will have another chance with the appellate court.

Further reflection reveals that the two procedural systems face disparate problems in trying to attune lay factfinders to actual evidentiary standards in the practical activity of deciding criminal cases. As the continental judges sit together, there is no need for the professionals to instruct their lay colleagues about the quantum of proof in advance of actual deliberations. Nor is advance information needed on how to handle possible factual doubts. If such doubts arise, the professional judge will advise the lay judges in the debate over specific facts, during in camera deliberations. It is, then, not surprising that very few continental systems require formal instructions on proof sufficiency for conviction. The situation on the common law side of our comparison is quite different. There is no informal exchange of views and advice between the judge and the jurors at deliberations. Instead -anticipating that some doubts concerning evidence introduced are very likely to arise-the law requires the judge to instruct jurors on the necessary quantum of proof before they retire. The instruction is in the form of a rigid and abstract formula.

At this point, before discussing the implications of this difference in approach, a preliminary matter needs clarification: is the quantum of proof in the two systems basically the same? Somewhat reluctantly, then, I must venture onto the very treacherous ground of comparing the formal doctrines and actual standards governing proof-sufficiency in the two systems.

That factual doubts in criminal cases should be resolved in favor of the defendant is a principle espoused by modern legal systems, irrespective of whether they belong to the common or civil law tradi-

fessionel dans la procédure pénale en Pologne, 50 Revue dE DROII PÉNAI ET DE CRTMrNOLOGIE 919,929 (1970). It is likely that some lay judges do not even bother to register their initial disagreement in view of the dominant position of the professional judiciary. This is particularly likely where the mixed panel is composed of an equal number of lay and professional judges. In this connection see the interesting Swedish provision on the weight of the vote cast by the professional judge, SwEDISH CODE, supra note $69, \mathrm{ch} .29$ § 3. For a more general discussion of the relationship between continental lay and professional judges see M. WEBER, RECHTSSOzIOLOGIE 288 (1960).

77 In some continental jurisdictions which have retained a modified form of jury trial there will be, just as in the Anglo-American orbit, no appeal from factual findings. The practical importance of the requirement to justify factual findings is sometimes overemphasized. While the requirement no doubt introduces an additional degree of rationality into the trial process and presents an obstacle against arbitrariness, many judges develop standard explanatory phrases in their written opinions which often obscure the reality of their conscious concerns. There is also the problem of attempting to explain other people's thought processes in formulating a decision. 
tion. Labels do change: continentals speak of the maxim in dubio pro reo, while common law lawyers talk of requiring proof "beyond a reasonable doubt." ${ }^{278}$ Moreover, the implications of the rule are differently perceived, especially as we focus more on details. ${ }^{79}$ Yet the core of the rule, the idea that the defendant should be accorded the benefit of factual doubt, seems an axiom of criminal justice shared by nearly all contemporary jurisdictions. ${ }^{80}$ Disturbing problems arise,

78 Both maxims seem to be of relatively recent vintage. Although it is usually stated that the phrase "in dubio pro reo" was first employed in 1811 by the German lawyer Stübel, recent research has shown that it reached the German courts only as late as the first decade of this century. Sax, Zur Anwendbarkeit des Satzes "in dubio pro reo" im strafprozessualen Bereich, in FESTSCERIFT Für ULRICH STOCR 143, 158 (1966). The reasonable doubt formula is said to have appeared in the last years of the 18th century. MCCORATCE'S HANDBOOK OF THE LAW OF EVIDENCE \& 341, at 799 (2d ed. 1972). Of course, the idea that the defendant should benefit from the adjudicator's factual doubts is much older: Some trace it back to Roman and even old Hebrew law. Those who designed the medieval inquisitorial proceedings provided for special types of verdicts in case of factfinders' doubts (absolutio ab instantia, plus amplement informé) and, thus, by refusing to acquit the defendant outright, repudiated the idea that he should benefit from the uncertainties of the factfinder. But it may be noted as a curiosity that even the inquisitorial system of legal proof, within the syntax of its values, showed tendencies to favor the defendant: for example, less evidence was needed to establish facts benefiting the defendant than those detrimental to him. See B. Carpzov, Practica Nova Irrperialis Saxomica Rerour Crimenalions, Pars III, questio 115, nos. 74-75 (Lipsiae (Leipzig) 1739).

The relationship between maxims on factual doubts and the presumption of innocence is subject to dispute, both in continental and in Anglo-American writing. Some believe that the two are synonymous. Others believe that the presumption of innocence has a broader meaning. It has also, they claim, an admonitory function, warning the factfinder to make his decision solely on evidence adduced in court, rather than on inferences from the indictment or even the arrest. Or, under another view, older on the Continent than in America, the presumption of innocence protects the defendant from onerous restraints during the criminal process. See Tribe, An Ounce of Detention: Preventive Justice in the World of John Mitchell, 56 VA. L. REV. 371, 404 (1970). Without lingering in these almost seraphic doctrinal spheres, let me make only a brief remark on this score. Even if the admonitory function of the presumption of innocence is disregarded and it is conceived of solely as expressing technical rules on the burden of proof, I fail to see how the two could be conceptually viewed as coterminous. The idea of proof beyond a reasonable doubt has, at least potentially, a wider reach than the presumption of innocence. The latter relates only to those facts which concern the defendant's guilt, while the former is related to many additional facts outside the guilt-innocence alternative (e.g., mitigating or aggravating circumstances, procedural facts, etc.).

79 For instance, various positions are taken on implications of doubts regarding facts unrelated to the defendant's criminal guilt (e.g., statute of limitations), or even some grounds for exemption (defensive issues) obviously related to guilt. There is also some controversy whether the maxim requires outright acquittals or is compatible with equivocal decisions expressing the fact that some doubts as to possible guilt remain (e.g., the Scotch "not proven" verdict, or the Italian "assoluzione per insufficienza di prove"). See A. De Marsico, supra note 19 , at 254 . What on the level of generalities looks like common ground thus, in fact, covers much disputed territory.

80 The maxim is also espoused by East European socialist countries. See $1 \mathrm{M}$. STrogovice, Kurs Sovetskogo Ugolonnogo Protsessa [A Course in Soviet Crmannat ProCEDURE] 358 (1968). Moreover, some Soviet writers go so far as to claim that the ideas embedded in the presumption of innocence are actually observed only in socialist as opposed to bourgeois criminal procedures. Cf. T. Dobrovorskaia, Printsipy Sovetsrogo Ugolovnogo Protsessa [Principles of Sovdet Crinminal Procedoure] 117 (1971). That there should be only declared harmony (and that arpeggio) in accepting the principle, and that it should even be used as a weapon in waging ideological wars should come as no surprise. As with many other vague legal maxims, it is high-sounding but commits us to little in actual practice. Only China seems to strike a dissonant note, openly rejecting the presumption of innocence. See Shao Chuan Leng, Justrce in Connumist ChINa 63 (1967). 
however, if one turns to the study of the actual meaning and precise character of "doubts" which must be resolved in favor of the defendant. Such questions are usually below the horizon of attention of academic civilian lawyers, but they also seem to be seldom subjected to candid and piercing analysis by more pragmatic common lawyers. ${ }^{81}$ The question, however, is of crucial importance to all novice adjudicators who need guidance on what doubts, if any, are compatible with a finding of guilt. The superficial though authoritative answer to this question is virtually unisonous in contemporary criminal justice systems: the factfinder must attain the subjective state of full certainty of the existence of guilt before voting for conviction.

Is the law's proclamation in harmony with actual adjudicative standards? Perhaps only those who never deviate into practicality and owe little allegiance to reality would actually believe that the answer is in the affirmative. If all imaginable hypotheses of innocence which the factfinder surveys in his mind before deciding the issue of guilt were in fact incompatible with a conviction, the practical activity of administering criminal justice would come to a standstill. Even where, as in criminal trials of all civil and common law nations, the tolerable margin of error is small and proof standards very high, the attainment of full certainty is an impossibly stringent requirement. Besides, it seems psychologically naive to assume that sufficiency of proof requirements do not change in the process of decisionmaking. They depend on a number of sometimes imponderable factors, such as magnitude of punishment, prior inquiries into guilt, dichotomy between physical facts and "inner" facts relating to mental state, and so forth. ${ }^{82}$ But although some would admit that decisionmakers occasionally re-

81 For a frank and perceptive analysis in the Scandinavian literature see Waaben, Criminal Responsibility and the Quantum of Proof, 9 SCANDINAvian STUDIES IN LAW 243, 274-79 (1965). In England, Glanville Williams has reflected on the line beyond which risks to the innocent become justifiable in the public interest. See G. Wrimauss, supra note 22, at 190 . In American writing Tribe has recently made some perceptive passing comments on this problem. See Tribe, Trial by Mathematics: Precision and Ritual in the Legal Process, 84 HARV. L. Rev. 1329, 1373-74 (1971).

82 That the risk of error in capital cases is least acceptable and causes the most stringent proof requirements is perhaps too plain to belabor. In the days of the "legal proof" system this was openly recognized. But even much later, in some instances well into the 20th century, a number of evidentiary systems retained the prohibition against conviction in capital cases on mere circumstantial evidence. The implicit premise was the idea that direct evidence is more reliable. $C f .2$ V. BAYER, JUGOSLAVENSKo KRIVIČNo

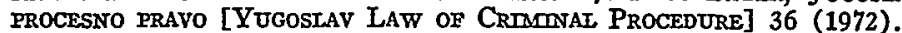

Regarding the impact of the distinction between physical and mental facts see Waaben, supra note 81 , at 277 . Thus, for instance, very demanding proof requirements will in actual practice be set concerning the question whether the defendant has fired a shot at the decedent. Much less proof will be required to become "convinced" of the intent to injure or to kill, although there is no legal presumption of intent stemming from the act of shooting. Such intent will in a sense be expected because practical experience tells us it is typically present. People seem to be unwilling to accept unusual situations, even where these are much more proximate than mere theoretical possibilities. 
quire less proof, for example, with respect to very exceptional facts such as those constituting duress or necessity, few would go a step further and openly acknowledge that degrees of tolerable doubt change too, so that tolerable doubt appears more as a sliding point along a continuum than a fixed entity. For my part I believe, horresco referens, that only the latter view corresponds to the psychological realities of adjudicative factfinding, and can only hope that at least novice adjudicators will privately bear me out.

But if my brief remarks may perhaps appear plausible to behavioral scientists, why is it that they fly in the face of the modern legal dogmatism and the proclamations of those who officiate before its altars? It is exceedingly difficult, perhaps even impossible, to articulate clearly actual proof standards applied in practice by experienced factfinders and the corresponding degrees of tolerable doubt in ascertaining facts. It also seems reasonable to fear that making explicit qualifications and reservations on the probably unattainable standard of absolute certainty might lead to the lowering of proof requirements for a finding of guilt. The complex curvature and fine shades of actual standards are absorbed in an imprecisely articulated form and gradually understood by the initiated. Their articulation and analytic dissection is thought to be harmful when disclosed to the uninitiated. Thus, the issue is relegated, perhaps with wisdom, to those sensitive areas in the penetralia of criminal justice where it is still thought advisable to distinguish between exoteric and esoteric knowledge. In short, the proclaimed views on the quantum of proof belong to the arsenal of useful legal myths, and the requirement of absolute certainty, in its form ad usum Delphini, plays a useful, though imprecise, exhortative role, psychologically conditioning the adjudicator to use the utmost care in guilt-determinations.

Assuming that the articulated standards on proof-sufficiency for guilt-determination are essentially the same in both systems and that actual standards in both systems are probably less demanding, what, then, is the consequence of the fact that the common law jurors must be instructed a priori on proof-sufficiency, while there is no such requirement for lay members of the continental mixed panel?

Imagine a professional judge presiding over the deliberations of the continental mixed tribunal who strongly disapproves of what he believes, in the light of evidence, is an unjustified tendency on the part of the lay members to acquit. Will he exacerbate his disagreement with lay adjudicators by admonishing them on the "in dubio pro reo" principle? It seems reasonable to assume that, in a typical case, the answer is in the negative. Consider now the corresponding situation 
after the common law jury trial. Here the anticipation that some doubt will always be a corollary of factfinding has led to the qualification, unparalleled on the Continent, that not all doubts have to be resolved in favor of the defendant, but only "reasonable" ones. I do not believe that this qualification plays a significant role in terms of its actual as opposed to "rationalized" impact on the jurors. But consider a case in which the common law judge would convict while some jurors tend to lean slightly in favor of the defendant, out of sympathy or some other motive independent of the evidence presented. True, the trial judge may, by the manner in which he delivers instructions, and, in a few jurisdictions, through his power to comment on the weight of the evidence, attempt to influence the jurors. Still, inexperienced and awed by their responsibility to decide on the destiny of a human being, will they not tend to grasp for an opportunity to avoid conviction by classifying their subjective state of mind as affected by a measure of "reasonable doubt"?

To conclude. The absence in the continental system of the requirement that lay judges be formally instructed on proof-sufficiency for conviction tends to reduce the difference between professional and lay adjudicators in their attitudes toward conviction. In contrast, the a priori, formal instruction on proof-sufficiency given to the common law jury by the judge may subtly increase these dissonant attitudes.

\section{Trial Structure and Evidentiary Needs}

In talking about disparate difficulties faced by prosecutors in persuading the factfinder of the defendant's guilt, a number of additional factors must be considered. They are independent of the layprofessional dichotomy, but are intimately linked to the different structures of the continental and common law type of trial. On several occasions I have mentioned that the continental trial is typically conducted in such a manner that the presiding judge is required to study the file of the case in advance of the trial. ${ }^{83}$ The extent to which this practice creates a danger of bias varies from country to country. It is less pronounced in those continental jurisdictions where pre-trial investigations are less thorough, and the investigating officer is not required to voice his opinion on whether the case deserves to be transferred to the court for trial. But whether from a comparative perspective the trial amounts to a verification of the record prepared by the investigator or is genuinely "creative," the impact of the dossier on guilt deliberations of the mixed panel cannot in candor be denied. While it is open to conjecture whether or not lay judges will be less

83 See note 16 supra. 
open-minded than jurors as a result of the knowledge that the case has been "objectively" investigated before trial, the fact remains that the professional judge will not approach the case as a tabula rasa. He will have an additional edge over lay assessors at deliberations as well: he will know more about the case than his lay colleagues. ${ }^{84}$

Another factor, seldom discussed, is relevant here. It is well known to experimental psychologists that different people have disparate cognitive needs; they often require different information, or ways of presenting it, in order to be persuaded of, or simply to comprehend a point. The continental trial is in a sense more attuned to this psychological phenomenon. All continental decisionmakers, lay and professional, are entitled to address questions to witnesses and take an active part during the presentation of evidence. ${ }^{85}$ On the other hand, common law jurors are passive observers of the examination of evidence, although, somewhat paradoxically, it is they who will have to decide the case. Their immediate cognitive needs are often unpredictable to the parties presenting evidence. It is, of course, possible that their general predispositions and needs may be elicited through voir dire or anticipated through the familiarity attorneys sometimes acquire with a small and relatively stable venire. But, on balance, more uncertainties and doubts are likely to arise, ceteris paribus, among jurors than among members of the mixed panel.

One can only surmise that the adversary method of presenting evidence is somewhat more conducive to uncertainties and doubts than the more organized and detached continental method. It is a truism that the more points of view we take into consideration, the harder it is for us to make a decision. When we view reality "through eyes other than our $\mathrm{own}^{2866}$ and are presented each side of the story in the most favorable light, it will become somewhat harder for us to become absolutely certain that only one side to an argument is in the right. Thus, it is possible to argue that the prosecutor will have somewhat

84 Although the professional judge is not supposed to inform the lay assessors of evidence not actually adduced before them, it is not inconceivable that he may on occasion be tempted to do so. Quite apart from this, his superior preparation and familiarity with the dossier will allow him to proceed with a speed and authority that cannot fail to impress his lay colleagues.

${ }^{85}$ Lay assessors do in practice exercise this right, although not as frequently as one might expect. See Casper \& Zeisel, supra note 23, at 149-50.

86 This, in Fuller's opinion, is the primary virtue and indeed the justification of the adversary system of presentation of evidence. Fuller, The Adversary System, in TaLrs ON AMERICAN LAW 30, 43 (H. Berman ed. 1961). Spiro has stated, in discussing the adversary trial and its implications, that the adversary style "contributes to lowering any conviction that only one side to an argument is in possession of all the truth." $\mathrm{H}$. SPIRo, GOVERNAIENT BY CONSTITUTION 230 (1959). A few passing comments on the complicated question of which manner of presenting evidence is a better means of discovering the truth will be made at the end of this study. See notes 218-20 infra \& accompanying text. 
more difficulty in sustaining the burden of persuasion under the adversary than under the continental style of presenting evidence.

\section{The Mechanics of the Persuasive Burden}

So far I have dwelt on those features of the two procedural systems which, as I see it, make the jury more reluctant to convict than the continental mixed panel seems to be. But even here offsetting tendencies are at work. Happily, only one of these is usually considered to be of major significance. In the common law system the burden of persuading the factfinder passes occasionally to the defendant, through the operation of some guilt presumptions and a number of so-called affirmative defenses. On the other hand, continental criminal law is said to have abandoned guilt presumptions in the course of the last century. Devices resembling affirmative defenses were also discarded in the belief that they were better suited to the private rather than public law style of litigation. As these differences between the two systems clearly affect the prosecutor's burden of proving guilt, it is tempting to assume that presumptive devices and affirmative defenses on the common law side counteract any greater burdens initially placed on prosecutors in the Anglo-American legal system. Let me consider guilt presumptions first and then turn to affirmative defenses.

\section{a. Guilt Presumptions Affecting the Burden of Persuasion}

That continental criminal law has discarded guilt-presumptive devices while common law courts frequently operate with them is by now a cliché of comparative law. Yet it frequently misleads casual observers for two reasons. In the first place, there are terminological pitfalls: "presumptions of guilt" do not mean the same thing to continental and common lawyers. In the second place, it is very easy to fall into the trap of comparing stale doctrine on one side with statements accurately describing current practice on the other.

Continental lawyers are traditionally very careful literalists. When they speak of genuine presumptions (presumptiones legis) they use the term in a narrow sense: they refer to devices which always shift the burden of persuasion, ${ }^{87}$ and are always mandatory in the sense that

87 In considering my references to the burden of proof in continental law the reader must note that burden of proof problems assume a special meaning in the context of nonadversary proceedings. Inasmuch as the continental court is under a duty to take an active part in discovering the truth, the burden on a party to establish a fact always "co-exists" with the duty of the court to ascertain the facts of the case. Small wonder, then, that continental evidentiary burdens seem strange to lawyers trained in the common law, and that some perceptive continental scholars claim that in a non-adversary procedural situation there is no allocation of proof burdens at all. See E. ScEMmr, DeUTSCHEs StrafprozessRecht 60 (1967).

While it is possible that the burden of proof rhetoric in the continental system of 
they require certain inferences from the proven fact. Unfortunately, the term "presumption" in the common law systems has "suffered badly from rough and careless handling"88 and this practice has left its imprint on guilt presumptions as well. Even so, it does not require much study to realize that most so-called guilt presumptions in common law criminal law reduce to permissive inferences; they merely allow the factfinder to make a finding of the presumed fact after he has established the basic fact. They do not require such a finding. For all practical purposes they amount to favorable comments on the inferential value of certain facts for a possible finding of guilt. Having thus translated the bulk of common law guilt presumptions as continental permissive inferences, both the continental law and continental adjudicative practices have to be scanned for functional counterparts. Of course, it would be futile to look for precise analogues: in the absence of a genuine jury trial, there is no need for the continental professional judges to instruct formally the lay factfinders on evidentiary matters. But, once again, let me attempt to lift the veil of secrecy surrounding the deliberations of the continental mixed tribunal. Experienced judges will admit that cases arise where they have to argue with lay assessors to correct their "misunderstanding" of evidence, mostly of the circumstantial type. ${ }^{89}$ Is it too daring to assume that in the course of such arguments they will often favorably comment on the inferential value of certain facts considered as proven by their lay colleagues? I am quite certain that well-devised empirical studies would reveal various interesting techniques developed by professional judges in dealing with psychological and epistemological problems lay assessors experience in decisionmaking. ${ }^{90}$ The actual impact of some of these techniques is, I believe, equal to, or perhaps stronger than, the impact on the jury of instructions relating to permissive inferences of guilt.

But even if most common law guilt presumptions (permissive

criminal evidence is an unnecessary borrowing from civil procedure, the fact remains that conventional doctrine uses the term. The Thayerian distinction between the burden of persuasion and the burden of going forward is traditionally not made in continental criminal as opposed to civil procedure. However, in continental legal scholarship there are some devices that express an essentially similar distinction. But this is no place to consider this very complex problem, connected as it is with the great scaffolding of continental (mostly German) generalization in the area.

88 J. Maguire, Evmence, Comparon Sense and Conaron Law 183 (1947). 519.

89 See the remarks of the Danish judge in H. KALVEN \& H. ZEISEL, supra note 72, at

$90 \mathrm{It}$ is sobering to note that continental judges will quite often experience difficulties in persuading lay assessors of the damaging character of evidence in many of those situations where a permissive inference (read "guilt presumption") appears in the instructions of the common law judge. A classic example is the problem of proving that the holder of stolen goods knew of their stolen character. See id. (observations of the Danish judge). 
inferences) do have functional counterparts in the civil law system, there remain a number of those which would be classified as stronger than permissive inferences, even within the continental classificatory scheme. As noted, continental doctrine rejects such devices unanimously as contrary to both the presumption of innocence and the in dubio pro reo principle. ${ }^{91}$ It will be difficult indeed to find them in continental criminal statutes. But the existing cleavage must not be exaggerated. Meticulous study of continental court practice might reveal an occasional genuine presumption, such as, for example, mandatory inferences of drunkenness from certain levels of alcohol in the blood. ${ }^{92}$

In sum, what appeared at the outset as a momentous difference seems, on closer analysis, to be only a minor discrepancy.

\section{b. Affirmative Defenses and the Burden of Proof}

The Anglo-American law on affirmative defenses is obscure and somewhat confusing. Analytically distinct issues are indiscriminately termed "affirmative defenses"; their relationship to criminal guilt and thus to the proclaimed presumption of innocence has not been sufficiently explored. ${ }^{93}$ Clearly, then, trying to relate affirmative defenses

81 The modern animosity toward presumptions is delightfully illustrated by Freud in his story about the man who was prosecuted for burglary. Proof that he had a jimmy in his possession was considered sufficient evidence of guilt. When asked whether he had anything to say, he begged to be convicted of adultery too, since he was carrying the tool necessary for that offense on him as well. 21 S. Freud, Standard Edition of Comiplete Psychological Works of Sigmund Freud 252 (1957).

Recently, presumptions of guilt in American law have been questioned on constitutional grounds. Cf. Turner v. United States, 396 U.S. 398, 425 (1970) (Black, J., dissenting); Ashford \& Risinger, supra note 54, at 176.

92 See, e.g., A. SchöNKE \& H. ScERöDER, STRAFGESETzBUCE, commentary to $\S 315 \mathrm{c}$, at 1564-65 (15th ed. 1970).

It is also terra incognita how many evidentiary problems, openly soluble by means of presumptive devices, are covertly "buried" in the substantive criminal law of both systems. This burial may take place in two main ways. First, in order to circumvent proof difficulties in proving an element of a crime, that element may simply be deleted from the definition of the crime. Second, if an exemption from criminal liability is difficult to litigate, it may be omitted from the corpus of criminal law. The continental vigor in preserving the presumption of innocence logically intact and the continental abhorrence of guilt-presumptions make it appear quite likely that a number of evidentiary problems are buried in continental substantive criminal law.

Due to the operation of such covert devices there is a degree of amusing confusion in comparative law discourse. I have heard lawyers from jurisdictions which refuse to accept mistake of law as an excuse at all criticize the A.I.I. Model Penal Code provision shifting the burden of proof with respect to mistake of law onto the defendant. The tenor of criticism was that such a solution violates the presumption of innocence and some related procedural ideas. Ieaving aside the question whether or not there are better ways to handle mistake of law, such criticisms verge on the ridiculous. At least from the defendant's perspective it is better to have a claim he has to prove than none at all.

93 Suffice it to offer only a few illustrations. Proceeding from what may be viewed as their pristine meaning, one would expect that affirmative defenses imply admission of the prosecution's case and introduction of new matter (i.e., "confession and avoidance"). While this is the case with some defenses, it is not so with alibis and many other contentions amounting to outright denials of guilt rather than its admission. Further, one might be led to believe that affirmative defenses require at a minimum that the defen- 
to their nearest analogues in continental law is presently a quite diffcult problem which, for our purposes, need not be explored at great length here. Let it suffice to juxtapose continental guilt-exemption grounds ${ }^{94}$ with those common law defenses that are admittedly intrinsic in guilt (or at least related to it) and which shift the burden of persuasion onto the defendant. Perhaps duress may be as good an illustration as any of the same issue, differently classified by the two systems.

The continental guilt-exemption grounds must be established by the continental court as part of its official duties. Moreover, in most civilian jurisdictions the burden of persuasion is not shifted onto the defendant and the quantum of proof is said to remain unaltered ${ }^{95}$ If we look at the same issues conceived as affirmative defenses in the Anglo-American orbit, the contrast is striking. Its implications for the comparison of prosecutorial burdens seem, once again, to be very considerable. If, however, we disregard the conventional continental doctrine and focus on the continental law in operation, the gap between the two systems begins to narrow. Consider a typical continental jurisdiction where the burden of proving a guilt-exemption is not shifted to the defendant. Although the issue here is, to use a common law term, part of the continental prosecutor's case, it seems hasty to assume that, in actual practice, the same very demanding standard of proof-sufficiency required for most facts falling within the definition of the crime will be required for the guilt-exemption. As I suggested before, the required quantum of proof is variable in practice: adjudicators are reluctant to believe in the existence of unusual situations and are more

dant put the matter in issue. But even this is not always the case. Consider the "affirmative defenses" which the judge may raise sua sponte, such as insanity and self-defense in many American jurisdictions. Finally, while some affirmative defenses merely shift the burden of going forward, others shift the burden of persuasion onto the defendant. Here some semantic clarity has been injected recently by those who insist on the distinction between mere defenses and afiirmative defenses. See, e.g., UNTTEd STates NatTonat Coaratssion on Reforam of Federat Crmminar Laws, Study Draft of a New Federai Crmatratar Code \& 103 (1970).

More serious to me is the uncertainty surrounding the relationship between criminal guilt and affirmative defenses. This uncertainty is the compound result of the relatively amorphous concept of guilt in common law jurisdictions and the confusing categorization of "affirmative defense." The problem is far from academic. If, for example, entrapment is considered a defense unrelated to actual guilt, shifting the persuasive burden with respect to this issue onto the defendant may somehow be reconciled with the dictates of the presumption of innocence. But, if a defensive claim, such as duress, negates criminal guilt, then shifting the burden of persuasion with respect to it onto the defendant simply means he has to prove his innocence rather than the prosecutor his guilt. One cannot then honestly maintain that guilt must be proved by the prosecution and guiltexemptions grounds by the defendant. One is only the obverse of the other.

94 By "guilt-exemption" grounds I mean issues which would, in the doctrinal frame of reference of most continental countries, negate either "illegality" (Rechtswidrigkeit) or guilt (Schuld). For details see H. Silving, Constrtuent Elements of CrIME 381-89 (1967).

85 This is not the case in all civil law countries. Thus, there is good authority in France for the opposite view. See G. STEFANI \& G. LEVASSEUR, supra note 5, at 21, 459. Consider also the account of Danish law in Waaben, supra note 81, at 246-47, 253-55, 267. 
readily "convinced" of what happens in the usual course of events." Now it is easy to see that most guilt-exempting grounds are outside the realm of the typical; if this were not so, continentals would probably incorporate them into the definition of the crime. Accordingly, continental legal folklore notwithstanding, the prosecutorial burden with respect to proving guilt-exemption grounds is somewhat relaxed.

Let there be no misunderstanding. Both presumptions of guilt and affirmative defenses exert an offsetting influence in the common law system and decrease the prosecutorial burden of proving the defendant's guilt. But I believe that their cumulative influence is not strong enough to nullify my conclusion that the common law prosecutor experiences more difficulties in persuading the jury of the defendant's guilt than his continental counterpart does in persuading the mixed panel.

\section{Summary and Perspective}

What final picture emerges from my discussion? Now that the judicial factfinding process has been examined in search of factors affecting evidentiary barriers, we are in position to note in a general way that each phase of factfinding activity appears to be a bundle of offsetting tendencies. Clearly, then, it is not easy to make conclusory pronouncements with great assurance. Yet I believe there is enough basis for stating that the common law prosecutor encounters more obstacles than his continental colleagues in all phases of factfinding activity. First, he finds it harder to surmount the admissibility hurdle, where his informational sources undergo the metamorphosis into technically competent evidence. He will also find that many more demands are made of him at the level of presenting evidence. Finally, as I have just attempted to show, the jury seems to be a factfinder more reluctant to convict than the continental mixed tribunal. In sum, the initial thesis about unequal evidentiary burdens appears to be correct.

Before I take up the problem of whether these disparate evidentiary difficulties are related to the nature of adversary and nonadversary proceedings, I would like to offer a number of brief observations. Some of these will try to place the problem of evidentiary burdens in a larger context. Others will go to possible implications of unequal evidentiary burdens, dealing not so much with more practical issues but rather with those of a more "perspectivistic" nature.

\section{The Interrelationship of Factfinding Styles}

It will be remembered that, in exploring prosecutorial evidentiary difficulties, I have contrasted only the most elaborate factfinding

${ }^{96}$ Note 82 supra \& accompanying text. 
processes in the two systems. As there are more than one in each system of criminal justice, we must now turn to the problem of their mutual relationship.

The range of differences among available factfinding styles is very narrow in the continental system of criminal justice. Whereas, as I have shown, the most elaborate mode is less refined and demanding than its counterpart in the common law system, the most summary one is not significantly different from the most demanding. Factfinding must always be judicial and only a few evidentiary rules of minor significance are relaxed. ${ }^{97}$ Also, and this is very important for our purposes, the continental defendant has virtually no influence on the question of which mode of factfinding will be used in his case. ${ }^{88}$ Rather, objective criteria are applicable: the more serious the offense, the more demanding the rules of evidence for its processing.

By contrast, in most common law systems of criminal justice, the range of differences of alternative factfinding modes is enormous. In marked contrast to the very elaborate and highly technical evidentiary style used in jury trials, there stands the very informal "administrative" factfinding preceding entry of a guilty plea. Furthermore, it is the common law defendant who decides which evidentiary mode will be used: he can plead guilty, thus obviating the need for any adjudicative factfinding at all; he may waive his right to a jury trial; or he may insist that his case be tried to a jury.

Now, it is probably true that the machinery of criminal justice in most common law countries would come under great strain, and perhaps even be paralyzed, if the great majority of defendants insisted on being tried under the full panoply of evidentiary rules. It is, accordingly, not surprising that various inducements developed in actual practice for defendants to plead guilty and thus limit the factinding activity to more informal police or prosecutorial inquiries. While it would be transparently naive to argue that only evidentiary problems are operative here (for there are other, more pressing ones ${ }^{99}$ ) it would be erroneous to deny their significance. Even if such factors as the

97 In principle there is always the need for trial with formal proof-taking (Berweiszwang). Only in the area of minor crime, some but by no means all civil law countries have devised mechanisms obviating the need for trial. This, for instance, is the case with the West German "Strafbefehlsverfahren." See West Geracan Code, supra note 5, §§ 40712. Administrative factfinding suffices, of course, in the case of mere administrative violations. See note 5 supra.

98 The limited degree to which the defendant can simplify proof-taking is illustrated by Yugostav Code of Crimtinal Procedore, supra note 5, art. 208, patterned upon the Austrian model. For an example in Japanese law see S. DANDo, supra note 16, at 372-73, 377-79. The Russian criminal procedure code of 1923, R.S.F.S.R. 1923 UgoL. ProT. KoD. art. 286, attributed a great importance to the defendant's confession, giving the judge the power to dispense with taking further proof if the defendant admitted his guilt. This provision was, however, always disputed, and was discarded in 1960.

99 These reasons are discussed in A. Broarberg, Cemaminat Justice 28-31 (1967). 
desire to avoid expense are assumed absent, there still remain compelling reasons to encourage guilty pleas solely on the ground of avoiding the demanding proof-taking of the adversary trial. There is probably in the factfinding area a point of diminishing returns in trying to make proof-taking an "obstacle course" for those who administer the criminal justice process. What the latter will rightly or wrongly feel as too severe a repression of a need for "efficiency" or as too high a barrier will be subtly circumvented or satisfied by following a quite different route. ${ }^{100}$ Naturam expellas furca, tamen usque recurret. ${ }^{101}$

But we need not pursue these conjectures further. Whatever the reasons, the fact remains that in America, at least, the intricate judicial style of factfinding is used in a small minority of cases; the great bulk of offenders are processed through the negotiated guilty plea mechanism. ${ }^{102}$ And if we consider prosecutorial burdens in the total volume of cases, what I have said regarding common law jury trials and fullfledged continental proceedings is no longer true. An opinion might even be hazarded that, on this broader plane, continental evidentiary standards for proving guilt are more demanding. This perhaps not too paradoxical phenomenon raises troubling questions of policy. Assuming that we are not bound by preexisting legal données, is it better to have a very elaborate evidentiary style which, in an age of ever increasing crime rates, we can afford to use only in a miniscule fraction of cases, or to devise factfinding systems which, while less demanding, might then be applied universally? It is almost like asking a lady whether she prefers an orchid once a year or a modest bouquet every day.

\section{Some Consequences of Unequal Prosecutorial Burdens}

Although, as I have just noted, the common law system places a heavier evidentiary burden on the prosecutor only in a very small number of cases, it would be erroneous to believe that the impact of this fact is consequently also negligible. Let me present a few illustrations from the field of criminal procedure first. Many possible consequences of unequal difficulties in proving guilt may pass unnoticed if

100 Enlarging upon Fuller's metaphor of the health and sickness of a legal system, L. Foller, ANatomy of THE LAW 6 (1968), and using Freudian terminology, the "due process" requirements may be termed the superego of the machinery of criminal justice and the needs of its administrators the $i d$. If the latter are repressed too severely by the superego, the whole system will display neurotic symptoms. Repressed needs will manifes: themselves in unusual and unexpected ways.

101 Horatids Flaccus, Epistolarum Liber Prtmos, Epist. 10, 24 (Orellius ed. 1844). 102 See President's CoMmission on LAW ENForcemment and adMTinistration of Justice, The Chatienge of Crmate an a Free Society 134 (1967). 
we remain engrossed in the domestic perspective. But if we are faced with the need to explain some characteristics of the criminal justice system to foreigners, new aspects of things once thought familiar immediately spring into sight. Reflect for a moment on the reasons for the surprise of most visitors from civil law countries when they learn that the American news media carry from time to time detailed reports on the activities of notorious criminal figures, while the latter remain at large and perhaps do not even have a record of arrest. To explain this strange phenomenon to foreigners, I believe we must begin by describing the greater divorcement between prosecutorial information and admissible evidence, on the near impossibility of "freezing" evidence before trial, ${ }^{103}$ and similar evidentiary peculiarities of the common law criminal process. Or, since I have mentioned the arrest record, let me note the fact that continental visitors will be astonished at the significance attached in America to such records. In their countries, very little, if any, significance is attached to records of arrest. Whence this difference? Part of it pertains, perhaps, to differential uses of arrest: perhaps the authorities are more prone to use arrest per se as a punishment in the United States. But, once again, unequal problems in following up arrest with a conviction remain part of the explanation. More subtle implications come to the fore if we analyze some sources of confusion in comparative legal discourse about problems of criminal justice. Thus, to offer only one illustration, words like "conviction" and "acquittal" do not refer to exactly the same underlying experiences in the two systems. The opposition between conviction and other modes of adjudicative disposition is more closely related on the Continent to the opposition between guilt and innocence than it is in America. This, in turn, helps explain disparate views about who is to bear costs of proceedings not resulting in conviction, as well as a host of related problems. ${ }^{104}$

If one turns to substantive criminal law in the common law jurisdictions, it is not hard to see the significant influence of the everpresent possibility of having to try a case to a jury, with all the concomitant evidentiary problems. It is, for example, entirely possible that the still

103 See notes 19-20 supra.

104 If, for example, the failure to convict a defendant is indicative of his innocence to a high degree, the argument that the state should bear the costs the defendant incurred becomes very compelling. Small wonder, then, that provisions to this effect will be found in some civilian jurisdictions. See, e.g., Russian Code of Crmminat Procedure, supra note 28, art. 107; WeST GeraAan CODE, supra note 5, art. 467; YugOSLAV CODE OF CrRminal Procedure, supra note 5, art. 92. (Italy and France, however, take a contrary view.) If, on the other hand, failure to prosecute successfully has little relationship to innocence, the demand for compensation of costs incurred by the defendant loses much of its vigor, although his costs may be very high-as is surely the case in America, where counsel's fees are comparatively very high and the defendant may spend money on private investigations, expert witnesses, and the like. 
markedly greater reliance on external or objective standards in the criminal law of common law jurisdictions is due in part to the much greater difficulty in litigating the actor's subjective state of mind. ${ }^{105}$ The more notorious and less controversial example is the conspiracy doctrine, so severely criticized by civilian lawyers and so frequently used in the practice of common law courts. Is not this frequent use related to the relaxation of evidentiary rules in conspiracy trials? ${ }^{108}$

With these brief remarks I conclude the discussion of evidentiary difficulties experienced by the common law and civil law prosecutors. Clearly, beneath many other distinctive features of both legal systems there sounds the leitmotif of concern for the evidentiary difficulties encountered by prosecutors. Though there are many avenues open to explore them, tracing the often tangled relationships between prosecutorial evidentiary problems and other features of each criminal justice system would require an independent study. It suffices for my purposes to have suggested that fruitful hypotheses can be put forward once unequal factfinding problems are recognized.

\section{Barriers to Conviction and Two Rival Procedural Models}

Part I sought to show that the common law jury trial presents the prosecutor with more evidentiary obstacles than does the continental criminal trial. Here my aim is to explore the common feeling that there is a link between unequal obstacles to conviction and the dichotomy between adversary and non-adversary proceedings. Unfortunately, before embarking on this large enterprìse, some preparatory work must first be undertaken. In both continental and American scholarship the expressions "adversary" (or "accusatorial") and "non-adversary" (or "inquisitorial") are used in a variety of senses, and the meaning of the opposition between procedural systems changes accordingly. Moreover, even within a single and more or less stable dichotomy, a degree of confusion remains. It is not at all clear which sets of features are determinative of the "adversary" as opposed to the "non-adversary" system. Each label seems to cover characteristics in shifting combinations,

105 This, of course, is not the historical explanation. But present opposition to more refined subjective standards is, I believe, linked to evidentiary problems continentals do not have to cope with. A case in point is the rejection by the draftsmen of the Model Penal Code of an analogue of what civil law lawyers would call "actio libera in causa" doctrine. See Moder Penal Code \& 2.08, Comment 3, at 7-9 (Tent. Draft No. 9, 1959). On the doctrine of actiones liberae in causa see H. JESCHECK, LeBrBdCH DES STRAFrechis: ALIGEMEINER TEII 293-94 (1969) and the comparative literature mentioned therein.

106 Perhaps the locus classicus on evidentiary benefits reaped by the prosecution in conspiracy cases is the concurring opinion of Justice Jackson in Krulewitch v. United States, 336 U.S. 440, 452-57 (1949) (Jackson, J., concurring). Continental criticism of conspiracy doctrine is succinctly presented in H. Sinving, supra note 94, at 161-63. 
not infrequently at war with one another. Finally, it is entirely possible that the opposition of procedural models most suitable for the purposes of this study is hidden behind the juxtaposition of a number of new models which, at least semantically, depart from traditional dichotomizing in talking about procedural types. Thus, a somewhat lengthy digression cannot be avoided: the meanings of both traditional and freshly coined labels designating procedural systems must be analyzed and an attempt made to explore their mutual relationship. As I proceed, the opposition between procedural types will acquire greater precision and, before quitting the digression, it will become possible to determine the conceptual tools most appropriate for my task.

\section{A. Essential Characteristics of Adversary and Non-adversary Systems}

\section{Continental Scholarship}

\section{a. The Historical Approach}

A quick glance at a conventional continental textbook on criminal procedure reveals that one of the first pontes asinorum continental law students have to cross is the mastering of distinctions among the accusatorial, the inquisitorial and the mixed (or reformed) ${ }^{107}$ criminal procedures. This traditional classification is historically grounded: it was created to summarize the development of procedural patterns as viewed from the continental perspective and within the usual continental parameters of interest. Both the taxonomical purpose and the circumstance that three procedural subcategories are involved imply that this classification does not afford a suitable conceptual framework within which to study the contrasts between modern continental and AngloAmerican criminal processes. Even so, a cursory sketch of the three procedural types under this classification must be attempted here. ${ }^{108}$ It will facilitate an understanding of the use of the term "inquisitorial procedure" on the Continent, and will illustrate the way in which continental lawyers classify their present criminal procedures.

Not much need be said here about the accusatorial type as defined under the historical approach. It was constructed with a dual purpose. The primary one was to offer a succinct description of procedures pre-

107 German lawyers prefer to speak of "reformed" rather than "mixed" procedures. Inasmuch as their label implies that the third procedural type is not a via media between the accusatorial and inquisitorial extremes but rather a variant of the inquisitorial type, their nomenclature seems preferable. $C f$. notes 121-22 infra \& accompanying text.

108 For a more detailed presentation of the historical approach see F. GarRADD, Tratté Théoretique et Pratique d'INstrdction Crtmmente et de Procédure Pénale, excerpted in A. Esmiein, A History of Continental Crintral Procedure 3-12 (J. Simpson transl. 1913). 
vailing in Europe from the fall of the Roman Empire, throughout the Dark Ages, and until the beginning of the thirteenth century. An ancillary aim was to provide a classificatory niche wherein to place the modern English criminal trial. ${ }^{109}$ This duality of purpose has led to an uneasy marriage-in the data-pool from which the type was constructed -of modern procedural ideas and primitive, even irrational ${ }^{110}$ procedural forms. It also accounts for certain unresolved ambiguities of the adversary type under the historical approach. ${ }^{111}$ In addition to procedural features familiar to common law lawyers, essential characteristics of the accusatorial type include elements such as "popular accusation,"112 trial by jury, and possibly even the absence of appellate procedure.

More attention must be devoted to the inquisitorial type as conceived by the proponents of the historical approach. In essence, the inquisitorial type is but a generalized description of criminal proceedings which prevailed in continental European countries from the thirteenth until the first half of the nineteenth century. The rough outline of this system is as follows. The criminal process was instituted by the investigator acting of his own motion in the form of a secret preliminary investigation. ${ }^{113}$ In its first phase the investigator's task was to de-

109 When the historical approach was in its heyday very little was known in Europe about the American criminal process. Another serious limitation of the data-pool from which the types were constructed was the absence of sufficient information about the criminal process preceding the judicial stages-for example, lack of awareness of the actual operation of pre-trial interrogation that might be conducted by justices of the peace. The significance of this limitation for the validity of the classification will be touched on later.

110 By irrational I mean procedural devices, such as trial by ordeal, which rest on religious imaginings, especially the belief that the deity can be summoned to intervene in the screening of the guilty from the innocent. On this ancient mode of trial in England see T. Plucknetr, A Concise History of the Comanon Law 113-18 (5th ed. 1956).

111 I cannot discuss here the difficulties arising from attempts to reconcile, within a single procedural type, features essential to factfinding in the Dark Ages and in modern times. Can contemporary systems be declared "impure"? Is it at all feasible to construct a "pure" type under the historical approach? Would such an attempt, by neglecting accidental historical accretions, inexorably lead from a historical to an analytical approach toward procedural systems?

112 Under popular accusation, the charges can be pressed by any citizen, irrespective of whether he has been victimized by the offense. It will be recalled that this system was used at the trial of Socrates, see Plato, Apology 24, in The Collected Diazogues of Plato 10 (E. Hamilton \& H. Cairns eds. 1961); R. BonNer, LaWyers and Litigants IN ANCIENT ATHens 44 (1927), and in the Roman Republic, see, e.g., A. Jones, The Crimanal Courts of the Roman Republitc and Principate 46 (Oxford 1972). This is still the theory of the British system, see R. ArguIIE, Crmmenal Procedore 20 (1969); KenNY's OutLines of CrIMINAI LAW 561 (18th ed. J. Turner 1962).

113 It must be emphasized, however, that in most continental jurisdictions, throughout the period indicated in the text, inquisitorial procedure coexisted with a type of proceeding which required an accusation (formal charge) as a prerequisite to any procedural activity. This latter type was considered by legal theorists of the epoch to be technically superior to criminal proceedings initiated by the investigating judge sua sponte. They referred to it as forma processus ordinaria (i.e., ordinary mode of proceedings). On the relationship between these two ways of handling criminal matters in medieval Italy and 17th century Saxony see B. Carpzov, supra note 78, Pars III, questio 106. See 
termine whether the crime had in fact been committed and the identity of the primary suspect. When the latter was found, the second phase of the investigation would begin, directed against a specific person. Typically, the defendant was incarcerated at this point and held incommunicado. Both he and the witnesses were examined ex parte and required to answer questions under oath; responses to all questions were put in writing. ${ }^{114}$ Until the investigation reached its final stages, the defendant was rather vaguely informed about the precise nature of the crime being investigated and the incriminating evidence. It will be recalled at this juncture that the law of evidence prescribed the kind and the quantum of proof required for conviction. ${ }^{115}$ In all offenses of some gravity mere circumstantial evidence was not enough to support a conviction: the only "legal proof" attainable was often the defendant's confession. Thus, in cases involving serious crime, if the defendant did not voluntarily confess, and the evidence gathered against him raised a strong probability of guilt, the investigator was long permitted to put the defendant to torture in order to extract a confession from him. ${ }^{110}$ When the investigator completed all investigatory activities he would send the file (dossier) of the case to a court for decision. The court would proceed on the basis of documents contained in the file, and in many countries would never see the defendant. In fact, there was no trial, but rather a closed session of the court. ${ }^{117}$ Public prosecutors, even where they existed, were not necessary for the proceedings to commence, develop, or terminate. Furthermore, in many countries the defendant had no right to assistance of counsel. ${ }^{118}$

This rough sketch of inquisitorial procedure should in itself suffice to explain the aura of dread and mistrust surrounding the adjective

also R. QUANTER, DIE Folter 168 (Aalen 1970) (photocopy of the 1900 Dresden edition). In practice there were numerous disincentives to bringing a formal accusation, notably in cases of serious offenses. Thus, victims, rather than file a formal "accusation," would prefer to report a crime informally to the investigating judge, who would treat such reports as just another informational source upon which to base his sua sponte activity. As a result, the so-called "ordinary mode of proceeding" became practically obsolete, except in the area of minor crime.

114 The answers were taken down verbatim. See, e.g., B. CARpzov, supra note 78, Pars III, questio 113. A special protocol ("Gebärdeprotokol") would contain descriptions of the demeanor of persons under interrogation. Cf. R. QUANTER, supra note 113, at 83.

115 See note 10 supra.

116 See note 215 infra. After the abolition of torture, inquisitorial proceedings adopted other coercive measures to enforce the defendant's duty to testify. Cf. note 41 supra; note 215 infra.

117 In this respect the French variant was more favorable to the defendant than the German. Under the French variant the defendant was at least permitted to see the adjudicators and communicate with them. In German-speaking countries the decision was for a long time rendered by law professors at what we would think of today as "faculty meetings" to which the defendant was never admitted.

118 "Learned and honest" (docti et probi) counsel were, however, admitted in inquisitorial proceedings of the German-speaking countries. See B. Carpzov, supra note 78, Pars III, questio 115, no. 93. 
"inquisitorial." I believe, however, that most of this aura is actually due to factors having little to do with inquisitorial proceedings per se. Partly, it results from confusing ordinary secular proceedings described here with those of the Holy Inquisition. ${ }^{119}$ Partly, it is a reflection of the harshness and cruelty of the substantive criminal law of the times. But, most of all, the pejorative note stems from the mistaken belief that the institution of torture was essential to the inquisitorial type. ${ }^{120}$

The mixed type was developed by European scholars to offer a generalized description of modern continental criminal procedures which replaced the inquisitorial process just described in the first half of the nineteenth century. It was then, in the wake of the French Revolution, that many features of the old procedural style became incompatible with the changed political and social climate. ${ }^{121}$ It is by no means easy to present the outline of this last procedural type under the historical approach. After all, it was designed to represent an eclectic mixture, and its flavor naturally changes as we go from jurisdiction to jurisdiction. Yet any presentation would probably reveal the following main characteristics.

The initial investigatory phase of the continental criminal process is correctly thought of as inquisitorial in its basic design. Howeverand continental lawyers set great store by this feature-the investigation can be instituted only at the instance of an "accuser," usually the public prosecutor. In the course of the investigation, the investigating judge, or some other purportedly impartial official, ${ }^{122}$ is charged with

119 The Inquisition was a special ecclesiastical court for the suppression of certain offenses against the Church, notably heresy. Its proceedings contained many departures from ordinary secular proceedings. Moreover, offenses falling within its jurisdiction were either imaginary, as for example the crimen magiae (witchcraft), or those of beliefs and attitudes more than specific acts.

120 In fact, inquisitorial proceedings-for example, early ecclesiastical procedure in criminal matters, see, e.g., DECRETUM GRATIANI, Causa XV, questio 6, in S. Von DooRNICE, DIE SUTMAa ÜBER DAS DECRETUM GratTaNI 221 (J. Schulte ed. 1965)-are known in which torture was not permitted. It should also be recalled that inquisitorial proceedings persisted in many European countries long after torture was outlawed. The mistaken link between torture and the essence of the inquisitorial system is only one instance of the many pitfalls inherent in the historical approach to types of procedure. Characteristics of inquisitorial proceedings of a given epoch, or a given country, are often proclaimed characteristics of the inquisitorial type. On the other hand, as $I$ indicated, supra note 111, if an effort is made to isolate the minimum of common features, one is moving away from the historical approach in the direction of building "pure" models.

121 Descriptions of mixed procedures are often based on the example of the $\mathrm{Na}$ poleonic Code of Criminal Investigation, Code d'Instruction Criminelle (1808), 9 BULIETIN DES LoIS DE L'EXIPIRE FraNçAIS 4th, No. 214 bis (1809), which was enacted following the rejection in France of the transplanted English criminal procedure. Although it is true that this code served as a prototype to many legislators in the civil law system, it would be mistaken to believe that it represented the first "mixture" of "accusatorial" and "inquisitorial" ideas. Criminal proceedings before the Star Chamber, for instance, were clearly such a hybrid.

122 As a distant echo of the inquisitorial distinction between the general and special investigation, some modern continental jurisdictions, such as France and Germany, distinguish between two types of preliminary investigation. One of them (enquête or 
the collection of evidence. But, in contrast to the inquisitorial style, at least some proof-taking activity is carried out in the presence of the parties. The rejection of the medievalist system of legal proof decreased the importance of the defendant's confession. The defendant may be questioned, but is no longer required to answer. At the close of the investigation, if not before, the defendant and his counsel acquire an unlimited right to inspect the file of the case. As a result there is full evidentiary disclosure before trial.

The procedural stages following the investigation are said to be predominantly accusatorial in inspiration. The dossier is transmitted to the public prosecutor, who must decide whether to bring the case to trial or not. There is no arraignment with formal pleadings before the trial judge. The trial itself is open: both parties are present and must be accorded opportunity for argument and debate. In principle, all evidence taken during the investigatory stage must be examined anew. Proof-taking is presided over by the professional judge. He is not only very active in questioning witnesses, but is also both authorized and required to raise all issues revelant to the charge. If necessary, he must even hear evidence not formally put forward by the parties. A final important point: trial proceedings are not bifurcated into guilt-determinative and sentencing phases.

If, at this juncture, we compare the central features of the mixed with those of the inquisitorial type, there is no question that the former contains many "accusatorial" ideas. If viewed against the background of continental legal history, we might even be tempted to place this third procedural type approximately midway between the extremes presented by the inquisitorial and accusatorial systems. From the common law perspective, however, it is possible that both inquisitorial and mixed procedures appear as two branches of a common parent stem, that of non-adversary proceedings. Even so, it would seem inappropriate to refer to this common stem as "inquisitorial." In view of the aura surrounding that term, reminiscent as it is of such odious features as unspecified charges, secret proceedings, and torture, all abandoned long ago, it seems unfair to continentals to attach it to their contemporary criminal proceedings.

Not much more than this lesson for comparative discourse ${ }^{123}$ can

Ermittlung) is usually carried out by the police, and the other (instruction preparatoire or Untersuchung) is entrusted to the judge. Under the Russian system, where the office of investigating judge does not exist, the latter, more elaborate type of preliminary investigation is carried out by officials of the Public Prosecutor's Office. See RUSSIAN Code of Craminat Procedure, supra note 28, arts. 117, 125.

123 While it is true that common law lawyers sometimes shock their civil law brethren in comparative dialogue by calling their procedure "inquisitorial," the latter have been known to reciprocate. Sometimes the Anglo-American procedural style is said 
be derived for my purposes from the standard classification of continental procedural types. It has many weaknesses, one of the most serious of which is the relative neglect of the highly important though poorly visible police stage of the criminal process. ${ }^{124}$ But, quite apart from these weaknesses, the historic orientation of the classificatory scheme coupled with the fact that contemporary continental criminal procedures are somewhat in the middle of the range between the two extremes makes that scheme unsuitable for the purpose of studying the contrast between modern continental and common law systems. The most striking differences between the two are not significantly related to the differences between "mixed" and "accusatorial" proceedings under the historic approach.

\section{b. Two Narrow Technical Views}

In discussing alternative ways of structuring criminal procedure, continental scholars sometimes oppose solely the accusatorial and the inquisitorial styles, using these two expressions in a narrow sense. Let me consider here two main instances of this narrow usage. The first one reduces to the conceptualization based upon only one of many reforms which led to the advent of the "mixed" procedures. It will be recalled that the inquisitorial investigator proceeded of his own accord: there was no mechanism either to spur him on or to set limits to his inquiries. In a sense, he acted both as factfinder and as prosecutor. This merger of procedural roles was severely criticized long before inquisitorial proceedings were rejected on the Continent. ${ }^{125}$ Of course, advocates of reform, steeped in the non-adversary tradition, did not go so far as to require that the adjudicative role be divested of so many responsibilities that it resemble that of an umpire. Only some of those responsibilities considered incompatible with the role of the adjudicator under a rigorous adversary approach were thought to endanger objectivity in factinding, and were thus eliminated. The ensuing reforms in the nine-

to be embedded in "primitive concepts" of the judicial role, or to be contrary to the "ontology" of criminal procedure. See 1 G. FoscrinI, supra note 44, at 227-28; S. DANDo, supra note 16 , at $83-84,175$.

124 This phenomenon is in the civil law system mostly the result of insufficient familiarity with the police stage of the Anglo-American criminal process. But, as I see it, this is not the whole explanation, inasmuch as a sizable group of continental jurisdictions is involved. The continental legal folklore generally tends to attribute more rigidity to the division among branches of the legal system than those trained in the common law can imagine. Since, in some systems, the initial police activity is not governed by the code of criminal procedure but is considered to belong within the domain of administrative law, it is simply not studied by procedural scholars. See note 191 infra. See also W. ScHAEFER, supra note 56 .

125 In German-speaking countries, where inquisitorial proceedings prevailed long after the abolition of torture, this was indeed considered as the single most important defect of inquisitorial procedure. This view is still shared by some eminent German scholars. See Schmidt, Introduction to WEST Geracar Code, supra note 5, at 2. 
teenth century broke up the much-criticized "personal union" of prosecuting and ascertaining facts, and entrusted the "severed" activity of prosecuting to a new procedural protagonist-the prosecutor. Since that time the adjective "accusatorial" is often used by continental lawyers to denote proceedings in which the prosecutor's charge is both a prerequisite for investigatory activities and the limit on the scope of inquiries. The term "inquisitorial" is applied to proceedings where there are no such restrictions on factfinding activity. ${ }^{12 B}$

To define the meaning of this dichotomy is to demonstrate that it is totally unsuitable as a conceptual tool for comparative purposes. For the "accusatorial" style, in this narrow sense, shares common ground with both the continental and the Anglo-American legal systems.

The second narrow use of the expressions "accusatorial" and "inquisitorial" involves juxtaposing the following two opposed procedural arrangements. Under the first ("accusatorial"), the defendant has the right to be present when procedural activities are underway and is entitled to offer counterproof and counterarguments. Under the second ("inquisitorial"), proceedings may be conducted ex parte and the defendant can be restricted in his defense. ${ }^{127}$ The first procedural arrangement, however, is still attuned to the continental ideal of the parameters of procedural choice. Accordingly, it does not contemplate that there will be partisan presentation of evidence and partisan zeal even though the defendant is present and active in court. Rather, it assumes a detached non-partisan examination of evidence in which the judge will play a dominant role. Thus, once again, many striking contrasts between the continental and common law styles remain outside the reach of these procedural polarizations.

\section{c. Procedural Models and the Analytic Approach}

If we remain within the mainstream of continental writing on criminal procedure, it is difficult indeed to find two rival procedural types expressive of the most important differences between the structures of the criminal process in continental and common law countries. The simple explanation is that the proper range of contrasts exceeds what to conventional continental thought appear to be the inherent

126 For a typical example see E. KERN, StrafVERFaHRENSRECHT 47-50 (8th ed. 1967). To explain better the reaction against medieval proceedings, perhaps I should note here that in minor offenses the medieval inquisitorial "investigator" was at the same time the adjudicator, and was not required to transmit a dossier to the court.

127 The first procedural arrangement is better known in Latin countries under the label of "procédure contradictoire" ("il contraddittorio"). At times the Latin maxim audiatur et altera pars denotes the same idea. See 2 G. Leone, Tratrato DI Diritro Processdale Penate 332 (1961). See also G. Stefant \& G. Levasseur, supra note 5, at 27-29. 
boundaries of criminal procedure. For instance, that the parties should be permitted to shape the subject matter of proceedings, through pleadings, stipulations, monopoly in raising issues, and in many other ways, seems to continental lawyers to be almost "ontologically" characteristic of civil rather than criminal procedure. ${ }^{128}$ However, as soon as we cross these "inherent" boundaries and move into the area of civil litigation continental style, procedural rules, devices, and operative concepts can easily be found to express the full range of differences between the two alternate styles of structuring criminal proceedings.

Recently, deeper understanding of proceedings in the common law orbit, including its American variants, has contributed to the receding of continental horizons of thought about the spectrum of differences in contemporary procedural systems. Perceptive continental scholars have become aware that, when viewed from the Anglo-American perspective, contrasts between current Eastern and Western European procedures begin to pale, and that even differences between "mixed" and "inquisitorial" systems lose their significance in many important respects. ${ }^{129}$ Thus a movement seems afoot to cut loose from the traditional, historically grounded triadism in categorizing procedural systems. But it must not be overlooked that the rejection of the historical orientation in approaching the problem of procedural types has an important consequence. Proceeding from striking contrasts between modern procedural systems, continental scholars try to identify underlying problems to which these contrasts are alternate solutions. What emerges from the juxtaposition of the two sets of procedural arrangements thus polarized is surely not a shorthand description of real-life procedures. Rather, two diametrically opposed ideal-types in the Weberian sense emerge, whose greatest value is heuristic. ${ }^{130}$ Using a more fashionable term, I shall call them models, and, in order to avoid the cluster of confusing associations surrounding the labels "inquisitorial" and "accusatorial," I shall refer to them as the adversary and the non-adversary models. At this point an important distinction must be made. Most of these

128 On what to continental lawyers are inherent boundaries between criminal and civil litigation, see K. PETERs, Strafrrozess 80 (1952) See also S. Dando, supra note 16, at 83-84; E. SCHMTD, StrafProzess UND RECETSSTAaT 206 (1970). Particularly confusing to conventional continental thought is a private law litigation style in a system which, like the American, rejected the idea of popular accusation. See note 112 supra.

129 Thus, such an eminent authority as Eberhard Schmidt has said that, inasmuch as the German court, rather than the prosecution and defense, shapes criminal proceedings, criminal procedure as practiced in West Germany is in essence inquisitorial. See Schmidt, supra note 125, at 10,18. Obviously, the expression "inquisitorial" is used in a new sense here. It denotes the opposite extreme of "Parteiprozess" (party-controlled proceeding) and is closely related to the analytical model of which I shall shortly speak in the text.

130 As will appear later, it may lead to confusion if models are regarded as repro, ductions of reality rather than methodological constructs of largely heuristic value. 
recent efforts toward constructing models remain, quite consistent with the continental legal style, on the technical plane of developing polar alternatives defined in terms of procedural rules and principles. There appears to be much less concern to articulate rival ideological preconceptions which might help explain the choice of radically different technical alternatives in structuring the criminal process. Even so, interesting developments occur on both planes and should be briefly surveyed here.

In first considering the technical legalistic plane, let me quickly outline the sequence of procedural ideas inherent in the adversary model. The fundamental matrix is based upon the view that proceedings should be structured as a dispute between two sides in a position of theoretical equality before a court which must decide on the outcome of the contest. The procedural aim is to settle the conflict stemming from the allegation of commission of crime. Since the proceeding is essentially a contest, devices such as pleadings and stipulations are not only acceptable but, indeed, essential because they establish the existence of a contest and delineate its borders. ${ }^{131}$ The protagonists of the model have definite, independent, and conflicting functions: the prosecutor's role is to obtain a conviction; the defendant's role is to block this effort. In his charge the prosecutor determines which factual propositions he will attempt to prove and must marshal evidence in support of his factual contentions. Not only does he have the burden of persuasion with respect to the latter, but also the burden of presenting evidence in court. In doing so he is expected to be partisan. The defendant decides which facts favorable to his theses he will attempt to prove, and must adduce evidence in support of all his factual contentions. He cannot be examined by the court, for reasons which will appear shortly, nor can he be questioned by the prosecution. For if only one side to a contest were to use the other as an evidentiary source, such practice would destroy the balance of advantages and the position of theoretical equality between the contestants. ${ }^{132}$ Furthermore, such practice would fly in the face of the idea of rival use of informational sources: the informational source and its partisan user would merge in the person of the defendant. The role of the adjudicator becomes that of an umpire who sees to it that the parties abide by the rules regulating their contest. Even here his basic attitude is one of passivity: he is to rule on the

181 Clearly, there cannot be a dispute if one side refuses to oppose the other. This is not, of course, the historical explanation of formal pleadings in criminal procedure.

132 This, also, is not the historical explanation. Historians tell us that the common law defendant was for centuries not allowed to testify because he was considered an interested witness. However, traces of the analytic incompatibility noted in the text occassionally surface in American writing. See AII Moder Code of Pre-Arratgnsment PROCEDURE \$ 5.01, commentary at 169 (Tent. Draft No. 1, 1966). 
propriety of conduct only upon the objection of the side adversely affected. When the contest is over the adjudicator must, of course, decide on the outcome. ${ }^{133}$ An important outgrowth of the fundamental matrix is a great number of technical rules regarding proper conduct of the protagonists. Proceedings tend to become "over-lawyered."

Many features of actual criminal procedures in common law countries are not essential characteristics of this model. Judgment by one's peers, ambushes as a result of lack of discovery, publicity, emphasis on oral testimony - these and many other features are not indispensable to the adversary model. Yet, as we shall see, the ideological assumptions underlying the model make many of these non-essential features a matter of natural choice. Borrowing a scholastic term, they are naturalia rather than essentialia of the adversary style.

Non-adversary proceedings emerge from the following central structural idea. Rather than being conceived of as a dispute, they are considered an official and thorough inquiry, triggered by the initial probability that a crime has been committed. The procedural aim is to establish whether this is in fact the case, and whether the imposition of criminal sanctions is justified. Of course, the matrix of an official investigation is incompatible with formal pleadings and stipulations: the court-controlled pursuit of facts cannot be limited by mutual consent of the participants. ${ }^{134}$ "Parties" in the sense of independent actors are not needed, and proceedings may, for instance, be a mere "affaire à deux." Factfinding is "unilateral" and detached. All reliable sources of information may in principle be used, and the defendant may be subjected to interrogation. Obviously, then, this much simpler structure of proceedings leads to fewer technicalities. The non-adversary model is, thus, "under-lawyered."135

Many historically-determined features of continental procedures are not essential to the model. It is, moreover, theoretically possible that the presentation of evidence could outwardly proceed in an adversary fashion, as long as the adjudicators were at least subsidiarily authorized to raise new issues, examine proof sua sponte, and hear evidence themselves whenever necessary to advance the official inquiry. But, once again, the ideological assumptions behind the model make

133 The adjudicator's passivity explains why it is that under the "pure" model the judge cannot interrogate the defendant. In locating actual American practices on the spectrum between the present model and its rival, the passivity of the jury in factinding should not be overlooked.

${ }^{134}$ Thus, even if the defendant declares that he is guilty, the inquiry must proceed in the ordinary fashion.

135 Not only is the technical scaffolding of procedure simpler; as indicated, legal counsel are not indispensable for the model to function. If they do appear, however, the more active the court, the less important their role. 
many features of real-life continental proceedings a matter of natural choice.

So much for the two analytical models devoid of ideological underpinnings. ${ }^{136}$ Turning now to the opposition of the two ideologies underlying the rival procedural models, we find little more in Western European writing than passing remarks and sporadic embryonic ideas in need of elaboration. Little effort seems to have been spent on the study of how broad ideological orientations determine the choice of procedural arrangements. ${ }^{137}$ However, where the issue of rival ideologies has squarely been faced, collectivistic values and benevolent paternalism were isolated as preconceptions of the non-adversary model, while traditional Lockean liberal values, with distrust of the state and freedom from its restraint, were found to be in the ideological matrix of the adversary model. ${ }^{138}$ More frequently than in the West, ideologically colored analyses of procedural systems will be found in the Eastern European writing. This leads me to a brief discussion of Marxist attitudes toward types of criminal proceedings.

\section{d. Procedural Types in Marxist Literature}

According to Marxist teachings, each socio-economic system, from the slave-owning to the socialist, generates its own distinctive type of law. The most important characteristics of that law emanate from the basic purpose of the legal order, which is to protect and further the values and interests of dominant social forces. Following this philosophic vision, students of criminal procedure in socialist countries thought it imperative to classify all existing criminal processes according to the socioeconomic system of the state which adopted them. Leaving aside problems of legal history, the most important task of the new taxonomers was to isolate distinguishing features of socialist as opposed to bourgeois (capitalist) criminal procedures.

136 A "third model" can be derived from this analytical point of view only as a synthesis of the two extremes. It is, however, seldom constructed. For an example of such a third model see G. FoscenNI, supra note 44 , at 230 .

137 This is not to say that there is not a great deal of writing on political, social, epistemological, and even psychological problems in criminal procedure. Most of this writing is devoted, however, to problems independent of the opposition between adversary and non-adversary criminal processes. See, e.g., the brief yet excellent discussion in K. PETERS, supra note 128, at 66-71. See also E. ScEmmor, supra note 128, passim.

138 For a rare example of this approach see G. FoscenNI, supra note 44 , at 226-30 (linking adversary proceedings with "individualism," and inquisitorial proceedings with paternalistic attitudes and socialism). On the phenomenon of judicial paternalism (paternalismo giudiziario) see the bibliography collected in G. Foscrun, supra note 44, at 232. A few stimulating insights can be found in G. RADBRUCH, GeIST DES ENGLISCHEN RECHTS 15 (4th ed. 1958).

Viewed historically, primitive adversary proceedings are usually explained in terms of weak state authority and little awareness of social danger emanating from criminal conduct. 
The difficulties encountered turned out to be formidable. All Eastern European countries, including the Soviet Union, belong to the continental legal tradition. The force of tradition being what it is, it seems quite natural that whenever the existing civil law rules, modes of thought, and institutions were not found to conflict with the new socialist order and its values, they were retained and built upon. This is precisely what happened in the domain of the criminal process: the criminal procedure systems of all Eastern European countries exhibit the unmistakable imprint of continental "mixed" proceedings. Thus, if one were to abide by the traditional criteria of continental systematization, he would be forced to admit that "bourgeois" proceedings in Western European countries are much closer to "socialist" procedure than is the adversary structure of Anglo-American proceedings. Most differences seem to lie outside any natural Marxist contours. Much as Max Weber had to admit that modern capitalism is equally well served by common and civil law techniques, so the Marxist students of procedure were forced to declare that bourgeois procedure can be either adversary or not. ${ }^{139}$ What resulted was the downplaying of the importance of this opposition by characterizing it as a mere form hiding the same bourgeoisified substance. ${ }^{140}$ But if the difference between socialist and capitalist criminal procedure does not reside in broad procedural design and in the rules of procedure and evidence, where is it to be found? Inevitably the emphasis shifted to attempts to describe the contrast both in terms of the actual operation of criminal justice systems, and in terms of the supporting economic, social, and political assumptions. This two-pronged Marxian approach need neither be merely a weapon in ideological wars nor a plaything of those who dwell in ivory towers. ${ }^{141}$ Unfortunately very little serious scholarship and no

139 M. WEBER, supra note 76, at 284. The examples Weber chooses to illustrate his point are more striking than the ones available in the law of criminal procedure. The latter is, relatively speaking, more neutral regarding socio-economic systems or factors, and perhaps more responsive to changes in the organization of political power. Obviously laws regulating ownership of property, for example, are much more intimately linked to social and economic structures. And yet, as Weber indicates, capitalist systems manage to operate in this area with vastly different conceptual tools, such as those connected with the Romanic "ownership" and those stemming from Anglo-American titles and estates. For a fascinating discussion of the reverse phenomenon, i.e., the use of similar technical concepts by widely different socio-economic structures, see Merryman, Torvard a Comparative Study of the Sale of Land, in 2 IUs PrIvatum Gentrom 737, 742 (1969).

140 Cf. Ugolovingi Protsess [Crincmal Procedore] 440 (M. Cheltzov ed. 1969). This does not mean that the importance of the traditional dichotomy is neglected altogether. See note 150 infra. Nor does it mean that some special characteristics of legal rules on criminal procedure cannot be isolated in socialist countries. This, however, is a rather difficult task in view of differences existing-on the level of rules-among individual East European states. Even so, it may be said that the influence of the Soviet example is very pronounced in all Eastern European countries save Yugoslavia. On Yugoslav departures from the Soviet model see Damaška, Foreword, in YogosLav CoDE OF CRTMTNAL Procedure, supra note 5, at 4-15.

141 Interesting inferences have been drawn, especially in the study of procedural 
empirical research has been done along these lines so far. This will become obvious to anybody prepared to wade through the rather drab prose on this subject, which is characterized by a mixture of mere verbiage, ideological rancor, and occasional stimulating hypotheses for future research. ${ }^{142}$

But I need not spur the reader on to this tortuous and tedious journey. The important question for my purposes lies outside the existing writing on the contrast between bourgeois and socialist procedures, no matter how these are defined. ${ }^{143}$ Notwithstanding the fact that the adversary and non-adversary models are not intended to depict the opposition of socialist and bourgeois criminal procedures, it is by no means impossible that one of the two models is better attuned to the ideological preconceptions and perhaps even to the structure of one of the two rival socioeconomic systems. The key to this analysis lies in the underlying assumptions and some salient characteristics of socialist procedure.

Surely one of the basic socialist values is an openly acknowledged and quite strong emphasis on collectivism, as opposed to the primacy of the individual. The all-important relationship between the state and the defendant in the criminal process will not be viewed as one of irreconciliable conflict. ${ }^{144}$ Perhaps, on a philosophical level, the very existence of a conflict between the individual and socialist society will be questioned. ${ }^{145}$ As the state power is said to be in the hands of the toilers-

systems in feudal societies where the social bias was openly expressed in procedural rules. For example, the use of torture was restricted in case of defendants belonging to the dominant social class. See note 214 infra. Even with respect to modern criminal processes, few would deny the interest of studies exploring the realities behind solemn proclamations that justice is administered on the basis of equality, studies concentrating on the influence of disparate social, economic, and political circumstances: Perhaps a whole new and more meaningful classification of modern criminal procedures could result.

142 See, e.g., M. CHertzov, supra note 140, at 440-56 (on bourgeois procedure), 425-40 (on socialist procedure); T. DobrovolskaIA, supra note 80 , at 117-18.

The prerequisite of serious scholarship in this area that is lacking in most Eastern European countries is a well-developed, empirically oriented sociology of law. Perhaps more important, it appears exceedingly difficult to avoid the temptation to compare proclamations on one hand with unearthed sociological facts on the other, and score facile points in the ideological war. Inter arma silent scientiae!

${ }^{143}$ I do not regard the definitions advanced so far as definitive.

144 Although, for example, rules can be found in Soviet procedure amounting to a conscious sacrifice of precision in truthfinding for the sake of other values, one cannot find passages to this effect in doctrinal writing as they would run counter to the prevailing legal folklore. Procedural safeguards are conceived of as mandated solely by concern for the reliability of the factfinding process. There also seems to be little recognition of the possible contradiction between the state's desire to ascertain the truth and the guilty defendant's desire to conceal it. Strogovich, for example, does not consider this possibility. See M. Strogovich, Kurs Sovetsigogo Ugolovnogo Protsessa [A Course in Soviet Crimtinal Procedure] 52, 58, 60 (1968).

145 See, e.g., Szabo, Le Droit Socialiste, in B. BLAgojevic, W. CzachorsKr, T. IoNASCo, V. KNAPP, M. KROUTOGOLOV, I. SZABO \& V. TOUMANOV, INTRODUCTION AUX DroIrs Socralistzs 9, 73 (Budapest 1971); Rakhunov, Dokazatelstvennoe Znachenie Priznaniia Obviniaemogo po Sovetskomu Ugolovnomu Protsessu [Evidentiary Signifi- 
the overwhelming majority of the people-distrust of those who administer the criminal process would seem misplaced. ${ }^{146}$ While safeguards against possible abuse must be developed, basic faith in public officials is thought justified, and the possibility of misuse of powers is not a primary consideration in devising procedural arrangements. Socialist conceptions of the purposes of the criminal process are changing. The role of criminal proceedings is conceived as much broader than merely applying substantive criminal law and punishing. ${ }^{147}$ Particular significance is attached to the educational function of proceedings, not only with respect to the defendant and other participants in the courtroom drama, but also with respect to the citizenry at large. ${ }^{148}$ The pervasive atmosphere is not one of scepticism regarding the possibility of establishing the real truth, and the meaning and morality of punishment; on the contrary, there is full confidence in the propriety of conceptions of crime and criminality as well as in the reliability of factinding. ${ }^{\mathbf{1 4 9}}$

I could continue this rough sketch of values underlying socialist proceedings, but the torso that has already emerged is sufficient for my limited purposes. Are these rhapsodic ideals more consonant with the procedural model of an official inquiry or with the model of a "battle" between the state and the individual before a purportedly neutral arbiter? Although I believe there is little doubt where the answer lies, I will suspend giving any answers at this juncture. ${ }^{150}$ The

cance of the Defendant's Confession in Soviet Criminal Procedure], 1956 SoverskoE gOSUDARSTVO I PRAVO [SOVIET STATE AND LAW] no. 8, at 34, 36.

146 State agencies are no longer agents of an oppressive minority "fired by a desire to pervert." Whatever supervision against abuse is needed can be exercised by the Party and the citizenry participating in the administration of justice. See M. Creitzov, supra note 142 , at $428-29$.

147 Note that for a long time after the revolution "punishments" were considered by the Russian Commissariat of Justice as measures of social protection rather than punishment stricto sensu. This Ferrian idea was, then, incorporated in the Russian criminal code of 1922, R.S.F.S.R. 1922 UGOL. KoD. art. 26. Currently the interplay between agencies of criminal procedure and "social agencies" such as the "comradely courts" is particularly important here. There is, in general, great willingness to go easy on those who repent, and "rugged individualism" is not considered a virtue.

148 Hence many procedural provisions appear bizarre when viewed from the Western perspective. Examples include the possibility of holding court in the locale linked to the crime involved, so-called "social accusers and defenders," assignment of cases to the comradely court, the "special [or "private"] decision" accompanying the regular judgment continental style and so forth.

149 Soviet views on this score revolve around the concept of "objective truth." See T. Dobrovolskata, supra note 80 , at 121-35; M. Cenertzov, supra note 140, at 88-97. Skepticism concerning the possibility of finding the real truth is declared typically bourgeois.

150 Cheltzov states explicitly that bourgeois procedure is "based" on the principle of adversary contest of the state and the individual before the adjudicator who is only said to be independent of the state. The concept of a "contest" is thus considered a mere ideological façade. Id. 440 . That the adversary idea is uniquely characteristic of bourgeois justice was also the view expressed by the brilliant early Soviet scholar E.B. Pashukanis. See E. Pashokands, La Théorie Générale du Drott ex IE MarXISMe 169 (Paris 1970). Strogovich, however, takes the view that Soviet criminal procedure, at least at the trial stage, is adversary in the sense that the role of the judge is separated from that of 
problem will be taken up in the next section, dealing with some procedural models framed by American lawyers.

\section{American Opinions and Scholarly Writing}

\section{a. The Manichaean Dichotomy}

In America, too, the expressions "accusatorial" and "inquisitorial" tend to be used somewhat indiscriminately at times. Various procedural patterns are loosely included under these labels, and the meaning of the opposition of the two systems remains somewhat obscure. It would seem to me, however, that the dichotomy often purports to represent the distance between the old continental inquisitorial procedure at its historic worst, and a variable selection of somewhat idealized features of modern American criminal proceedings. Thus, for instance, a system which leads to the use of coercive measures to extract the defendant's testimony is opposed to a system which relies on evidence "independently secured through skillfull investigations." tem predicated on the presumption of guilt is contrasted with its counter-ideal founded on the presumption of innocence. ${ }^{152}$ As I see it, the problem with this polarization is that it is Manichaean. It seems to suggest that the only alternative to some lofty conceptions of Due Process is a lapse into the horrors of a procedural system where charges are not specific, the accused is not accorded the benefit of doubt, his confession is coerced, his detention before trial is unlimited, he has no right to counsel, and is not advised of his constitutional rights. ${ }^{153}$ Whatever the merits of this dichotomy as a weapon in the war between -in the late Herbert Packer's terms-the Due Process and Crime Control factions, surely the differences between modern continental

the prosecutor and in the sense that the defendant is accorded certain rights in order to defend himself. This is a reflection of conceptions of socialist democracy. See M.

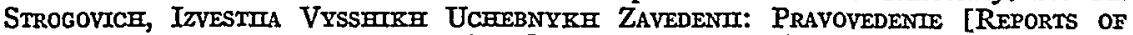
Hitgher EdUCATIONAL INSTItUTIONS: LAw] (transl. no. 2 1962). Of course, his opponents can always reply, in Marx's phrase, that the Soviet criminal procedure is here "mit einer buergerlichen Schranke behaftet," i.e., that it (temporarily) encompasses bourgeois elements.

151 See, e.g., Miranda v. Arizona, 384 U.S. 436, 460 (1966); Watts v. Indiana, 338 U.S. 49,54 (1949).

152 This line of analysis has been criticized as inaccurate in Ploscowe, The Developopment of Present-Day Criminal Procedures in Europe and America, 48 Harv. L. Rev. 433,436 (1935).

153 These are all aspects of inquisitorial procedures cataloged by Justice Frankfurter in Watts v. Indiana 338 U.S. 49, 54-55 (1949).

I have shown that there were many inquisitorial procedures (e.g., in German-speaking countries) in which the defendant had a right to counsel, see note 118 supra, while at the same point in history the English adversary trial did not admit counsel in felony cases. Or, take modern systems. Whether or not continental or common law charging papers are more specific is not at all certain and would deserve a separate study. That the defendant should be advised of his "constitutional rights" is obviously a very parochially conceived feature of adversary proceedings, unknown, for example, in the United Kingdom. 
and Anglo-American criminal procedures cannot meaningfully be studied within this Manichaean framework.

\section{b. A Narrow View}

The continental concept of the "mixed" type of criminal procedure, while not unknown, has never gained currency in common law countries. ${ }^{154}$ A narrow continental way of conceiving the contrast between the accusatorial and the inquisitorial style, seems, however, to have a rough analogue. Fuller has said, for instance, that " $[t]$ he essence of the adversary system is that each side is accorded a participation in the decision that is reached, a participation that takes the form of presenting proofs and arguments. ${ }^{1155}$ Lack of opportunity to present proof and arguments would, then, presumably be the essence of the inquisitorial system.

It would appear at first blush that, if the core of the adversary style is conceived in this fashion, there is no difference between modern continental and common law systems. It will be recalled that the continental defendant is accorded "participation" in the above sense, at least at the trial stage, and frequently even during the preliminary investigation. Closer examination reveals, however, that important differences remain. It is perfectly clear, for instance, that the active role of the continental judge appears from the common law perspective as too gross an interference with the conduct of both the defense and the prosecution, even in the eyes of those who, like Fuller, do not consider judicial passivity as essential to the adversary style. Moreover, continental parties do not present their evidence and arguments in a manner that would be considered partisan or active enough to common law lawyers. More important, if our purpose is to find the proper parameters within which to study the contrasts between modern continental and Anglo-American procedural patterns, then the narrow view is unacceptable. Many other significant considerations should be taken into account over and above the contrasting manner in which arguments are made and evidence examined by the adjudicator.

\section{c. Rival Models of Procedure}

The adversary system and its antipode are at times constructed more broadly by common law lawyers. Here the core of the opposition seems to lie in alternative ways of conceiving the adjudicator's role: judicial passivity (the umpire) is juxtaposed with judicial activity (a

154 But cf. H. BerMan, JUSTICE IN THE U.S.S.R. 304 (1963).

155 Fuller, supra note 86, at 30, 41. Compare Fuller's views with those of E. KERN, supra note 126. 
researcher pursuing the actual facts). I cannot here meticulously trace the implications of these two contrasting premises, but I believe they come very close to the two continental analytical models I have suggested earlier. There is, however, one significant difference. The question whether the parties can shape proceedings or not is not as central in common law as it is in continental thinking. ${ }^{156}$

But rather than canvassing the fine shades of difference in this basically similar approach, I shall dwell for a while on attempts by American scholars to articulate two diametrically opposed sets of assumptions said to underlie the choice of procedural patterns. The relationship of these rival ideologies to the contrast between adversary and non-adversary procedures must be established.

More than two decades ago, with his penetrating sense and remarkable breadth, Karl Llewellyn contrasted the "parental" and the "arm's length" systems of criminal justice. ${ }^{167}$ The keynote of the first is attitudinal: it resides in a feeling of togetherness, or "We-ness," in Llewellyn's idiom, between the miscreant and the group-government. The defendant is viewed as an integral part of the community, a member of a going team. ${ }^{158}$ There is no distrust of officials, who harbor parental emotions, even feelings of love. ${ }^{150}$ The goal of any activity directed toward the miscreant is to reintegrate him into the community, through repentance and open confession. Thus, punishment, when imposed, is not thought of as merely a deterrent or simple vengeance; it becomes an educational tool. Official action finds broad popular support and procedures are simple.

The "arm's length" system of criminal justice is the antipode of the "parental" type just described. The defendant is not viewed as a member of a team here, but rather as a "person quite outside," whom the officials are to take hold of only if they can pin upon him some specific act. One of the basic characteristics of the system dictating policy choices is distrust of officials. In keeping with the fundamental "detached" tone, the goal of the official activity towards miscreants is a narrow one: if it were to go beyond punishment, too momentous an invasion of the culprit's personality would occur.

156 As an example of this broad view contrasting judicial activity and passivity see Ploscowe, supra note 152, at 433-37.

157 See his article on the anthropology of criminal guilt, reprinted in K. LrewELLYN, JURISPRODENCE 439, 444-50 (1962). His description of the "parental" system is based on anthropological studies of primitive tribes, but his discussion shows that he detects the same system behind procedural, correctional and even attitudinal characteristics of modern criminal justice systems. Those bent on tracing the history of this procedural model in Anglo-American writing should perhaps begin with Bentham's "domestic" or "natural" model. See J. BenthaAs, A Treatise on Judicial Evidence 7 (M. Dumont transl., London 1825).

$158 \mathrm{~K}$. ILEWETIYN, supra note 157 , at 448.

109 Cf. id. 449. 
Implications flowing from these two "ideologies" were only outlined by Llewellyn, but no doubt remains that, in the procedural domain, opposing policy choices result in two technical-legal models strikingly resembling the opposition between non-adversary and adversary proceedings. ${ }^{160}$ As between these two poles, Llewellyn expresses a preference for the former "when it works well."161 He also believes that the former is better suited to a cure-and-prevention approach towards the criminal sanction. ${ }^{162}$ However, Llewellyn is aware of the lessons of history, which teach us how easily the parental ideology can be abused and the problems involved in controlling crime simplified. Thus, as a final choice, he favors an admixture combining the best features of the parental and arm's length systems. ${ }^{163}$

More recently, John Griffiths has constructed two diametrically opposed ideological models of the criminal process along almost identical lines. ${ }^{164}$ One he calls the "family" model, the other the "battle" model. While the latter is predicated on the idea that there is in the domain of the criminal process an irreconciliable conflict between the individual and the state, the former is based on the proposition of reconciliable interests, even a state of love. ${ }^{105}$ While the family model implies a basic trust in public officials, the battle model is characterized by a lack of faith in them. The family approach prevents fractionalization and a narrow view of the functions to be fulfilled by the criminal process; its antipode leads to "conceptual compartmentalization" and the blacking out of possible educational purposes of the trial besides the "meting out of deterrence."108 Unlike Llewellyn, Griffiths tells us very little about the procedural arrangements which would be likely to flow from the adoption of these two rival ideological roots. There are even passages in his essay which suggest that he does not feel that the "family" ideology would require radical departures from the adversary style. ${ }^{167}$ Thus, I have no way of knowing his personal views

160 Id. 444-45.

161 Id, 448 .

162 Grafting "a cure-and-prevention line of treatment" to the adversary procedure seems to Llewellyn as "a sort of institutional semi-schizophrenia." Id. 46.

163 Id. 447-49.

164 Griffiths, Ideology in Criminal Procedure or A Third "Model" of the Criminal Process, 79 YALE L.J. 359 (1970).

165 Id. 371. At id. 416 n.189, Griffiths speaks of the "possibility of forgiveness."

166 Id. 376-78, 388-91.

167 See id. 383, where Griffiths doubts that the Family Model "would involve less reliance on counsel, since there are good reasons for an adversary process which have nothing to do with irreconcilability of interest." Although he does not specify what these good reasons are, one that comes to mind is the belief that adversary presentation of evidence is a better factfinding tool.

Yet it is easy to think of examples in which the adoption of "family" ideology has led to the rejection of adversary features in judicial proceedings. Consider only the 
on the dictates of his ideological models in the choice of available procedural design. But, if it were necessary, I could easily show in detail that, much as with Llewellyn's two models, at least Griffiths' "parental" ideology leads to a procedure with a distinctive nonadversary flavor.

The attentive reader must have noted long ago the striking similarity between Llewellyn's "parental" and Griffiths' "family" model on the one hand and some ideological assumptions behind socialist criminal procedure on the other. ${ }^{168}$ Lawyers in socialist countries would probably dislike the epithet "parental" when applied to their system. ${ }^{169}$ They would, perhaps, consider the family and parental models as mere caricatures of their own assumptions. But, if the semantic hurdle be surmounted and the exaggeration inherent in all models recognized, I believe that scholars in socialist countries would concur in the opinion that the "family" ideology is indeed much closer to their own ideological tenets than is the "battle" concept. They would also be prepared to subscribe to the view that, as a result of their basic policy orientations, the technical procedural rules of an adversary model are totally alien to them. In sum, what Llewellyn and Griffiths seem to have done is to present two possible ideological justifications for the rival adversary and non-adversary models of the criminal process. ${ }^{170}$

extent to which, in America, the parens patriae ideology has affected juvenile proceedings. What finally prompted the Supreme Court to require adversary elements in juvenile proceedings was surely not a belief that such elements flow from the parens patriae approach. Rather it was the realization of the wide gulf existing between "parental" proclamations and actual practice. See In re Gault, 387 U.S. 1, 15-17, 27 (1967). Of course, it would be rash to suggest that the parental ideology necessarily leads to intolerable procedural lasness or unfairness. Non-adversary proceedings to contain safeguards, such as adequate notice, records of hearings, and right to appeal.

168 See text accompanying notes 144-50 supra; cf. text accompanying notes 137-38 supra (on "ideological" models in Western Europe).

169 They would particularly resent the implication that defendants are treated as less than aduits.

Let me note in passing that, until 1958, the Soviet system of criminal justice resembled Llewellyn's "parental" model on one more point: there was absent the "technical requirement" that crimes be defined by law prior to their commission. If, in fact, the essence of crime is "social dangerousness," crime can-to borrow Llewellyn's phrase-be expected to be foreknown as such in that it clearly runs counter to the tone and purpose of going institutions. Comradely courts are even closer to the "family" style of treating miscreants, but cannot be treated within the purview of this Article.

${ }_{170}$ An objection may be anticipated here. How can the Family Model be the basis of such typically non-adversary proceedings as the medieval inquisitorial type? To pick an extreme example, can torture and extraction of confessions be consistent with the desire to reconcile the offender with the community? Not only is this theoretically possible, but torture was actually frequently rationalized along these lines. Moreover, it would be erroneous, I think, to oppose love in one model to hatred in the other. Hatred and love are extreme forms of emotional involvement with the defendant, and it is true perhaps that les extrêmes se touchent here. The more appropriate polar opposites of love toward the miscreant are coolness and emotional distance. Quaere: Is not parsimony in emotional commitment an "arm's length" attitude, perhaps essentially "bourgeois?" See G. SteINER, The Pythagorean Genre: A Conjecture in Honor of Ernst Bloch, in LANGUAGE AND SHENCE 78 (1967). 
Perhaps better known than the preceding are the Due Process and Crime Control models of the criminal process developed by Herbert Packer. ${ }^{171}$ These two models must be presented in a nutshell and their meaning carefully scrutinized in order to establish their relationship to the opposition between adversary and non-adversary procedures. The distinguishing characteristic of the Crime Control model is its heavy stress on the need to repress criminal conduct, which leads to the demand that the criminal process be efficient in screening the guilty from the innocent. Thus, speed and finality are placed very high in the hierarchy of values underlying this model. ${ }^{172}$ Quite naturally, then, administrative processing is preferred over judicial. Indeed, in its purest form, the Crime Control model favors exclusive non-judicial factfinding "leading (1) to exoneration of the suspect or (2) to the entry of a plea of guilty."173

The Due Process model is complex. Its ideology is said to have two main strands. The first is embedded, as with the Crime Control model, in the area of concern for factfinding reliability. But, in contrast with its rival, the Due Process model favors judicial processing because it reduces the possibility of error. ${ }^{174} \mathrm{~A}$ further distinction, again based on precision in factfinding, is that the Due Process model is prepared to sacrifice efficiency in the interest of minimizing error. ${ }^{\mathbf{1 7 5}}$ It is, however, the second strand of Due Process ideology which accounts for the most important difference between the two models. If stripped to its barest essentials, it consists of the belief that individual values are paramount and that official power must be limited. ${ }^{176}$ In sum, if the Crime Control model in its pure form leads to an "assembly line" process, its polar opposite requires that the process be structured as an "obstacle course."

On the surface it might appear that Crime Control values must be associated with "inquisitorial" thinking, whereas the values of its

171 See H. Packer, Tare Limits of the Crmminal Sanction 149-73 (1968). The essay originally appeared as Packer, Two Models of the Criminal Process, 113 U. PA. L. Rev. 1 (1964).

$172 \mathrm{H}$. PACKer, szlpra note 171 , at 158-59.

$173 I d$. 162-63. With exclusive non-judicial factfinding nothing remains, however, of the common grounds between the two rival models, especially those Packer noted at 157. 174 Id. 163-64.

175 Id. 164-65. A pure Due Process Model, says Packer, has a very low demand for finality. As long as there is an allegation of factual error, there must be an opportunity for an adjudicative hearing. Id. 164. At this point, and in anticipation of further analysis, the following question arises. Is this review available only from findings of guilt, or also from findings of innocence?

For a discussion of the Due Process Model's relative concern with false findings of guilt and false findings of innocence, see note 184 infra \& accompanying text.

$176 \mathrm{H}$. PACKER, supra note 171, at 165.

177 Id. 163. 
antipode coincide with "accusatorial" assumptions. Packer makes it perfectly clear, however, that his "polarization" is limited to clashing assumptions animating the modern American adversary system. ${ }^{178}$ Specifically rejected also is the possibility that Packer is contrasting the divorce between actual practice and the law on the books. ${ }^{179}$ What, then, is the meaning of his opposition of two models? Here we must tread carefully. For, although admirably written-or, perhaps, precisely because of occasional flights of language-Packer's argumentation concerning the two models is not always tightly woven.

Notwithstanding sporadic passages which seem to suggest the contrary, ${ }^{180}$ closer reading reveals that he does not purport to contrast two rival ideal-types in designing the criminal process. True enough, his Crime Control Model may be conceptualized as such. It has a positive content, and efficiency in screening suspects may, standing alone, be imagined as an "animating assumption" in shaping criminal procedure. But "the Due Process Model is basically a negative model,"181 and it is conceptually impossible to imagine a criminal process whose dominant concern is a desire to protect the individual from public officials. In its pure form it would lead not to an obstacle course, but rather to mere obstacles and no course on which to place the former. Now, this problem seems to be solved by the introduction of the other "strand," rooted in the concern for factfinding precision. Posito sed non concesso that this additional strand provides the minimum positive content. Even so, the resulting hybrid is not a pure model. Indeed an internal conflict is possible between the desire for reliable factfinding and the concern for individual rights. ${ }^{182}$ Also, the very nature of polarization is somewhat fanciful in view of the fact that, admittedly, ${ }^{183}$ the Due Process Model is not the converse of the Crime Control Model.

What, then, is involved in the confrontation? Before I venture my own interpretation, I must take the liberty of rethinking the Due Process ideology along the lines suggested by its author, and of changing its content slightly. What are the actual reasons for the preference in the Due Process Model of judicial over administrative factfinding? Is it really the desire to increase the factfinding precision? I believe that the answer is in the negative. Factfinding in any criminal pro-

178 Id. 154-58, 172 in fine.

179 Id. 153.

180 Here I mean his reference to "pure" Due Process and Crime Control models, e.g., id. 164,172 .

181 Id. 173.

182 For example, exclusionary rules of evidence extrinsic to the desire to establish the truth may be objectionable to advocates of the reliability strand, while quite acceptable to the proponents of the individual primacy strand.

183 H. PACKER, supra note 171, at 163. 
cedure has a dual purpose: we want to convict the guilty and acquit the innocent. Unfortunately, there is a conflict between these two desires: the more we want to prevent errors in the direction of convicting the innocent, the more we run the risk of acquitting the guilty. ${ }^{184}$ In other words, there is a "cognitive dissonance" between the desire to minimize false positives and the desire to minimize false negatives. With this dilemma in mind, let me return to the reasons for the preference for judicial factfinding in the Due Process ideology. As I see it, the reason is not a desire to eliminate mistakes irrespective of the distinction between false positives and false negatives. The prospect of convicting an innocent is viewed with so much more horror in the Due Process ideology that it is even prepared to sacrifice factinding precision in the totality of cases. If my analysis is correct, then there are not two strands in Due Process thinking-the dominant concern for individual rights and the ancillary concern for factfinding reliability-but solely the former. The preference for adjudicative factfinding emanates from the cluster of ideas revolving around the primacy of the individual, rather than from the concern to be more precise in establishing facts.

Now if one juxtaposes the thus "purified" Due Process Model and its antipode, the meaning of the confrontation becomes obvious. Labels are beguiling; what Packer is in fact offering us are not two models of the criminal process. Rather he is presenting, within the framework of the American criminal process, a stimulating depiction, rich in implications, of two clashing inner tendencies: the tendency toward efficiency and the tendency toward protecting the rights of the defendant. But-and this I want to underscore-this inner tension is part and parcel of the dialectics of any criminal process. Any design of criminal procedure, even the extreme inquisitorial one, ${ }^{185}$ must establish a balance between these two (and some other) inner tendencies. ${ }^{188}$ This is not to say, however, that the manner in which

184 See J. HaLl, Studies IN JURISprudence aNd CrImINaI TheorY 220 (1958); Tribe, supra note 81 , at 1386.

185 As only the Crime Control tendency or one of the various supporting ideologies behind it can be conceived of as a model, it might appear at first blush that at least the ideology of efficiency can be equated with the ideology of such an extreme as the medieval inquisitorial procedure. However, that procedure was a response to the legal syntax of those days, which contained elements opposed to efficiency-for example, emphasis on judicial factfinding, and an exacting system of legal proof. Consider also the debate between abolitionists and retentionists of torture as an example of a clash, within inquisitorial procedure, between "output" and "quality" concerns, or "crime control" and "due process" people.

186 William Seagle has concerned himself with the conflict between impartiality and efficiency, and has criticized procedure as an "obstacle race" from the efficiency viewpoint. W. Seagle, LaW: THE SCIENCE of InEFFiciency 62 (1952). For examples of other clashing tendencies set forth in continental and Anglo-American writing see $\mathrm{K}$. PETERS, supra note 128, at 66-71; R. Pound, CrIminal Justice IN America 59-61 (1945). 
this dilemma is being resolved is independent of the contrast between adversary and non-adversary procedures. It would seem to me that the pure adversary model tends to resolve the conflict in a synthesis coming closer to the Due Process ideology than does the non-adversary model. The reasons for this will appear in the following pages where I shall explore the relationship between evidentiary barriers to conviction and the contrast between adversary and non-adversary criminal procedure.

\section{Choice of the Proper Dichotomy}

Various meanings attributed to the expressions "accusatorial" and "inquisitorial" have been surveyed. Some other conceptual constructs of possible use in studying the contrast between adversary and non-adversary procedures have also been canvassed. Hopefully, this long digression has led to enough clarifications to offer, in Robert Frost's phrase, "a momentary stay against confusion." Before returning to the problem of evidentiary barriers, what remains to be done is to choose an opposition of adversary and non-adversary procedural structures that is most suitable for my purposes.

I believe that the opposition most revealing in its ramifications is the one contrasting the internal logic of the procedural design of an official inquiry with that of party contest. ${ }^{187}$ It is true that the contrast has been criticized. ${ }^{188}$ For the most part its descriptive value has been questioned. The two rival procedural designs are said to be mere caricatures of real-life processes. No existing system, the critics say, coincides with implications flowing from the two opposing designs. The basic theme either of inquiry or contest is orchestrated in real life with heavy borrowings from the other camp, so that, as a result, all criminal processes appear mixed. ${ }^{189}$ To indulge in this kind of criticism is to voice disapproval of the use of models in general. For all models are by definition suggestive caricatures and simplifications departing from reality. I believe it is to Weber that we owe the paradoxical dictum to the effect that in order to grasp the real context we have to construct an unreal one. Thus, even if the descriptive utility of the two procedural models is denied-and I believe it cannot fairly be-there remains the heuristic value. ${ }^{190}$

187 See, e.g., text accompanying notes 128-38 supra.

188 Cf. Fuller, supra note 86, at 40-41. See also Kunert, supra note 23.

189 For example, the American judge is not totally passive, especially in criminal cases. Further, he need not accept a guilty plea in certain circumstances.

190 The descriptive value of the two models is, of course, limited. By liberating us from the tyranny of details like those described in the preceding note, the models enable us to perceive the grand contours of real-life contrast. The heuristic value inheres in the conceptual framework provided by the two models for the comparative analysis of such 
Sometimes the thrust of the criticism goes to the fact that the dichotomy concentrates on the judicial stages of the criminal process, neglecting the all-important initial phases. I find this criticism justified. ${ }^{191}$ Surely a comprehensive comparison of modern criminal processes requires the framing of new models. ${ }^{192}$ But my discussion is focused mainly on the judicial stages so that-in this limited areathe two models are satisfactory. With this reservation in mind let me return to my main theme.

\section{B. Rival Procedural Systems and Commitment to the Discovery of Truth}

In approaching the problem whether there is a link between the difference in evidentiary barriers to conviction and the contrast between adversary and non-adversary procedures, a good starting point seems to be the following question: Why are evidentiary barriers against conviction erected at all?

It is analytically possible to imagine a few of them as stemming from concerns shared by all evenhanded searchers for the truth, irrespective of their areas of endeavor. The aim of such barriers is to prevent the decrease in the precision of screening the guilty from the innocent. In a sense, they are value-neutral: acquittal of the guilty is viewed with the same disapproval as conviction of the innocent. More often than not, evidentiary rules serving this purpose will not even be perceived as "barriers" by those who administer the criminal process. ${ }^{193}$ The pursuit of truth in the criminal process is not an untrammelled exercise in cognition. Modern procedures in particular view with much more horror the prospect of convicting an innocent person than they do the prospect of acquitting the guilty. ${ }^{104}$

diverse issues as the relative importance of counsel and procedural form, and, as we shall see, the commitment to the pursuit of truth in the criminal process.

191 The data-pool used in constructing both the historic and analytic procedural types does not include the low-visibility police inquiry. Comparison of police procedures is quite complicated: in many continental jurisdictions, the judicial stages cover a larger segment of the total process than is the case in Anglo-American jurisdictions. Furthermore, although the police phase can hardly be imagined as "adversary" in any country, it will derive part of its specific flavor from the circumstance of whether the police anticipate an immediate adversary judicial phase or an intermediate judicial investigation.

192 This is another practically unexplored area in comparative criminal law analysis.

103 Consider, for example, the use of uncorroborated confessions. Such confessions are inherently unreliable as tools for the screening of the guilty from the innocent, and a rational system must prohibit their use. This prohibition will be perceived as a barrier only in pathological cases in which the administrators of the criminal process use a criminal conviction as a means of punishing a person irrespective of whether they were persuaded of the defendant's guilt with respect to the offense charged.

194 Even the old inquisitorial proceedings reflected, in at least one respect, a greater concern over unjustified convictions than inaccurate acquittals; they required less evidence for facts favorable to the defendant than for those detrimental to him. See note 78 supra. 
Accordingly, many evidentiary rules presenting obstacles to conviction are inspired by the desire to minimize the chances of convicting an innocent even at the price of increasing the chances that a guilty person may escape punishment. ${ }^{195}$ Although these rules display a bias, in the sense of favoring prevention of false positives even if it implies reducing the number of accurate results in the totality of processed cases, it would be mistaken to deny that they too are grounded in considerations of factfinding reliability. But there are many evidentiary barriers against conviction totally independent of the epistemology of normal procedure, limiting the search for truth and deliberately reducing factfinding precision for the sake of other values. Some testimonial privileges, rules excluding reliable evidence illegally procured, and many facets of appellate procedure belong in this group. ${ }^{196}$

Imagine that in one procedural system considerations of finding out the truth are more important than in another. What are the likely consequences? How will the two systems resolve the conflict between efficient pursuit of the truth and protection of values such as human dignity and privacy and the preservation of a general atmosphere of freedom? The one placing a very high premium on these other values will often remain committed to them even at the expense of truth discovery; in this sense it will be less "truth oriented" than the system for which values unrelated to truth discovery are less weighty. The more "truth oriented" system will be less willing to erect those evidentiary barriers that are independent of the concern for factinding reliability. But, even among barriers related to factfinding precision, there will probably be an important difference. Maximizing the number of correct verdicts may run counter to the desire to minimize the number of false convictions. The stronger the commitment of a system to truth discovery, the lesser the number of guilty defendants the system will be prepared to see acquitted for the sake of preventing the conviction of an innocent person. This attitude will, in turn, cause the

105 The most obvious example is, of course, the widely-accepted requirement of proof beyond a reasonable doubt. Many problems are, however, quite controversial. Thus, the unlimited discovery allowed the continental counsel is classified by some as a postulate of even-handed factfinding. Others of a more authoritarian bent claim that these rules reflect a bias in favor of preventing false positives (false convictions), and against preventing false negatives (false acquittals).

196 While this all will be considered almost banal by many American readers, it is quite controversial in many foreign jurisdictions. For example, it is often claimed that evidentiary privileges are based on a desire to avoid evidence of dubious value. Also, the exclusion of some illegally obtained evidence is said to increase factfinding reliability in the long run.

I often wonder whether this exclusive emphasis on truthfinding considerations emanates from seriously held beliefs, or amounts simply to an attempt to psychologically condition the administrators of the criminal process. They are more hospitable to arguments concerning prevention of factual error than they are to arguments extolling the primacy of the individual, human dignity, and similar values. 
more truth-oriented system to be less tolerant of those evidentiary barriers which act primarily to minimize the chances that an innocent person will be convicted.

But can it be said that one of the systems places a relatively higher premium on truth discovery? Many believe that there is no difference on this score: the objective of both systems is the same search for the truth. ${ }^{197}$ Here I must disagree. Indeed, I contend that the continental non-adversary system of procedure is more committed to the search for truth than is the Anglo-American adversary system. Plunging headlong into a much debated issue, I shall now attempt to marshal support for this contention on three planes: in the contrasting structure of criminal proceedings, in conflicting ideologies supporting it, and in historic considerations.

\section{Pursuit of Truth and Procedural Structure}

Broad pronouncements by judges and scholars in the two rival systems on the purposes of the criminal process may be dismissed by some as mere ritual incantations. It is possible, however, that they are symptomatic of deeply rooted beliefs and that a fleeting glimpse may be caught in them of the relative weight attached to the search

197 For a recent example of this view, voiced by a noted comparatist, see Jescheck, supra note 55 , at $240-41$.

Truth is, so the argument goes, equally important to both systems. They differ only in assessing the weight of other values which may and often do compete or conflict with the desire to find out the truth in the criminal process. Assuming, thus, the value of truth discovery to be a constant in the equation, these scholars would rather speak of differences between the two procedural systems in terms of weight placed on values other than that of ascertaining the truth. This mode of analysis has, no doubt, a certain attraction of which I will talk in a moment. But. I do believe that it is based on a misconception of the way in which conflicting values work in the area of criminal procedure. These clashing values operate as Dworkin's principles and policies. See Dworkin, The Model of Rules in LAW, REASON, AND Justice 3, 19, 30 (G. Hughes ed. 1969). We cannot determine their absolute but can only sense their relative weight. What is involved here is a process of balancing, of establishing the resultant of forces pointing in differing directions. Thus, even assuming that the value of discovering the truth can be determined to be equal in the two systems, if one of them considers values opposed to it to be less weighty, it ipso facto places greater relative weight on the value of discovering the truth.

Even so, many prefer to discuss the problem in terms of relative commitment to privacy, individual dignity and similar values, rather than in terms of different commitment to the pursuit of the truth. As I indicated before, note 196 supra, I find this preference to be anchored in procedural pedagogy. In discussing procedural problems-even in academic contexts-many scholars are concerned about the impact of their thoughts on those who administer procedural systems. The latter are believed to be more sensitive to fact-finding considerations than to values competing with them. It is feared that telling these people that one system is more oriented toward truth discovery than the other will be interpreted by them to imply praise for that system and a veiled invitation to redress the balance in the other system in favor of an unrestrained pursuit of truth. These fears may perhaps be realistic. Even so, I prefer to cast my discussion in terms of varying commitment to the discovery of truth, because I believe that this approach is more accurate and possesses greater explanatory force. Those who dislike my conclusion that the adversary system is less committed to discovery of the truth may rephrase it so that the system is said to be more attuned to other important values.

Note in this connection that continental civil procedure has fewer and less potent devices for ascertaining the truth than does the common law, especially in its American variant. See, e.g., M. Cappedretri, J. Merrmaran \& J. Permlo, supra note 10, at 138. 
for truth. It is openly stated by some common law lawyers that the aim of criminal procedure is not so much the ascertainment of the real truth as the just settlement of a dispute. ${ }^{108}$ Even allowing that this may be an exaggeration, the statement still sounds iconoclastic to continental ears. In talking about ends of the criminal process continental lawyers place a primary emphasis on the discovery of the truth as a prerequisite to a just decision. Considerations impinging upon the search for the truth are characterized as merely limitative, restricting somewhat the primary objective of truth discovery. The latter, however, remains the dominant aim to be achieved in a "socially acceptable way. $" 1199$

Let us see whether this legal rhetoric can be traced to our polarization of the two rival procedural models. Consider the "contest" model first. Almost imperceptibly, the emphasis shifts here from problems of cognition to the concern that parties abide by the rules regulating their "battle." In the conceptual realm of the party contest, it seems perfectly acceptable that a party, perhaps in the right on the merits, "lose" on a technicality-if he violated the rules regulating the contest. The judgment itself is not so much in the nature of a pronouncement on the true facts of the case; it is, rather, a decision

108 See, e.g., J. Coutts, The Accused: A Comararative Study 14 (1966); H. SpIro, GovernManT BY CoNstrTurton 227 (1959); Goldstein, supra note 61, at 1149; Hammelmann, supra note 9, at 78. See generally T. ARNord, THE SYMBOLS OF GoverNMENT 18385 (1935); K. LLEWELLYN, supra note 157, at 445-46.

190 The revered continental concept of substantive truth (Materielle Wahrheit) originated in the Germanic tradition of amplitude and thoroughness in philosophic inquiry. Sometimes considered as merely exhortative and addressed to those who administer the criminal process, it is at times also conceived of as an invocation to the legislator, urging him to discard procedural rules hampering the objective of truthfinding, no matter how much these seem warranted for other purposes. For a stimulating analysis of this question see 1 V. Bayer, Jugostavensko Krrvično Procesno Pravo [Yugoszay Law of CrTMmal Procedure] 173-86 (1969).

Discussion of this "procedural principle" vanished almost completely from newer German writing, but is still widespread in other continental countries, with the exception of France and jurisdictions under its strong influence. Particular importance is attached to this principle, renamed the "principle of objective truth" among scholars in socialist countries. Here we also find lengthy discourses about the "nature of the truth," linking cognitive skepticism to bourgeois values. See, e.g., T. DoBrovolskaIA, supra note 80 , at 41 .

Even those continental students of procedure who would go very far in restricting truth discovery hold that it is an essential objective of the criminal process inasmuch as it is a precondition to a just decision, the true ultimate aim. See, e.g., K. PETERs, suppra note 80 , at 68. For his views on limits to the pursuit of truth see Peters, Beweisverbote im deutschen Strafverfaliren, in VERHANDLUNGEN DES SECESUNDVIERZIGSTEN DEUTSCEEN JURISTENTAGES 91,160 (1966).

A relatively recent West German study has deviated from the conventional continental view regarding the achievement of justice through truth discovery as the ultimate end of criminal procedure. The real ultimum, according to its author, is the reduction of disruption of the community caused by the probability that a crime has been committed. See Schmidthäuser, Zur Frage nach dem Ziel des Strafprozesses, in FESTSCRRIFT Für EBERHARD SCEMIDT 511, 523-24 (1961). Schmidthäuser's arguments bring him closer to common law thinking on ends of criminal procedure, and offer ample food for thought, far beyond my subject. 
between the parties. ${ }^{200}$ If, however, proceedings are structured as an official inquiry, the concern for ascertaining the facts of the case is much more central. ${ }^{201}$

Lest it be objected that the problems are discussed only grosso modo, let us descend to more specific issues. An example obviously in point is the impact of the adoption or rejection of formal pleadings and stipulations in criminal procedure. If proceedings are patterned upon the model of an official determination of the facts of the case, both formal pleadings and stipulations are objectionable. The defendant, although in fact innocent, may plead guilty, or may stipulate damaging matters, for a variety of reasons. ${ }^{202}$ An official inquiry must, therefore, disregard possible interparty arrangements, and pursue the search for the real truth; confessions do not relieve the continental judge of his duty to conduct the trial in the usual manner. On the other hand, if proceedings are essentially a contest, and the judgment a decision between the contestants, the logic of this procedural design naturally tends toward accepting formal pleadings and stipulations. ${ }^{203}$

200 See G. Foschonr, supra note 44 , at 227-28.

Although attacked by many as an exaggeration, there is, I believe, something to the analogy between the "battle" model and the sporting event. In the latter, an athlete can be disqualified for a technical breach; considerations of fairness assume great weight. In her fascinating and colorful traveller's report, Sybille Bedford comments on the "unfairness" of the continental system. She does not question the accuracy of continental factual findings. Her point, rather, is that in Britain the prosecutor would seldom be able to present "so complete a case" as the German prosecutor, and that British defendants would have "a rather better chance of getting away with it." She is concerned about the "unlimited probing" in continental procedure. "The sporting spirit, the notion of the law as a game of skill with handicaps to give each side a chance, is entirely absent on the Continent." S. BEDFORD, supra note 17, at 163 . See also R. Pound, supra note 186, at 163; G. RADBRUCH, GETST DES ENGLISCHEN RECHTS 15 (4th ed. 1958).

201 See G. FoschenI, supra note 44, at 229.

$202 \mathrm{He}$ may want to undergo punishment for pathological reasons, or to protect the real culprit, as well as for a variety of tactical reasons in the dynamics of the criminal process (e.g., to establish a false alibi). But-and this is important in continental thought - he may not even know whether he is actually guilty. Guilt is not a factual but rather a legal problem, to be explored at trial. A word of caution here. Continentals do not distinguish factual and legal guilt along the lines suggested in H. PACKER, supra note 171, at 166. Indeed, they would be very critical of Packer's inclusion, in the concept of legal guilt, of issues such as venue, jurisdiction, or even the statute of limitations.

Some empirical data on West German trials with and without the defendant's confession can be found in Casper \& Zeisel, supra note 23 , at 146-51. In $42 \%$ of the cases studied the trial was held notwithstanding the existence of a full confession at some stage of the proceedings. Of these about $80 \%$ were first given to the police and the remaining $20 \%$ to the judge. True, cases in which the court had a full confession required less time for disposition at trial, but the differences were not as significant as Americans would expect. The deliberation time differed hardly at all. Id. 150-51.

203 In America the judge must, in principle, look into the factual basis of a guilty plea. Although this is analytically a departure from the pure adversary model, the heavy emphasis in America on the defendant's own strategic interests in deciding whether to plead guilty would still be viewed with unmitigated horror by adherents of the non-adversary model. For a good example of the contrast between the two systems see the discussion of pleading problems in Christie \& Pye, Presumptions and Assumptions in the Criminal Law: Another View, 1970 DUKE L.J. 927, 931. Their arguments on whether the guilty plea may be accepted even though the defendant maintains that he did not commit the crime in question, appear to a typical continental lawyer to be broadcast on a quite different wavelength of values. 
Or consider the problem of pre-trial disclosure of evidence. ${ }^{204} \mathrm{It}$ will be remembered that, even under the analytic approach, lack of discovery is not of the essence of adversary proceedings. It can hardly be gainsaid, however, that a "battle" model is more hospitable to the idea of "procedural ambush" and surprise, while the "inquiry" model will have nothing but scorn for this "perverted" way of searching for the truth. I could go on with examples of procedural patterns more or less acceptable to either of the two models in the light of their differing commitment to the discovery of truth. But in doing so I would probably belabor the obvious. Let me, therefore, pass briefly to the impact of the two rival ideologies.

\section{The Search for Truth and Ideological Preconceptions}

Ideologies supporting the choice of procedural systems are both vague and controversial. Various beliefs and concepts constituting these ideologies can easily be used at times to justify almost diametrically opposed procedural solutions. ${ }^{205}$ Yet there is, I believe, at least one strand of "adversary" ideology with a quite definite thrust in the direction relevant for my purposes. As I have suggested before, the adversary system in its modern variant is inspired to a great extent by an attitude of distrust of public officials and its complementary demand for safeguards against abuse. Accordingly, the adversary system is quite tolerant of evidentiary barriers limiting the search for the truth for fear of abuse of governmental power. Moreover, it does not view as unnatural the use of the criminal process itself "as the appropriate forum for correcting its own abuses,"200 thus making possible the reversal of "substantively" just decisions on "technicalprocedural" grounds. It stands to reason that as a result of greater hospitality toward such ideas, the factfinding potential of the system must somehow be decreased. Concern to establish the "real truth" has serious competitors in "collateral" considerations under the adversary system; guilt and innocence are not paramount.

By contrast, the ideology supporting modern non-adversary procedure, be it in the "family" or some other variant, while not ignoring

204 Justice Brennan voiced the thought that discovery "is the most effective device yet fashioned for the reduction of the aspect of the adversary element to a minimum." Brennan, The Criminal Prosecution: Sporting Event or Quest for Truth?, 1963 Wase. U.L.Q. 279, 291. Goldstein says, however, that discovery "has as its object the harnessing of the full creative potential of the adversary process." Goldstein, supra note 61, at 1180.

205 In the preceding pages only some ideological models were outlined; others could easily be constructed. Further, recall the uncertainty of the implication of the family model. See note 167 supra \& accompanying text. I believe that the family model leads inexorably to non-adversary procedure, though others, no doubt, will vehemently disagree with me.

208 See H. PACKER, supra note 171, at 167 in fine. 
the potential danger of abuse, exhibits much less distrust of police, prosecutors, judges, and public officials in general. Accordingly, many procedural safeguards and technical rules, acceptable to the ideology of adversary procedure, are dismissed as unjustified loopholes, "unnecessary obstacles of pedant legal etiquette," ${ }^{207}$ or impermissible injections of collateral issues into the search for guilt or innocence.

Assume, furthermore, that a general mood of skepticism permeates the ideology of adversary procedure. This skepticism would then relate not only to the possibility of establishing the truth, but also to the "morality and utility of the criminal sanction." of truth in this and similar contentions, then there are other factors rendering the adversary ideology more tolerant of restraints on the search for the truth, or, in other words, more committed to the pursuit of other values.

\section{Commitment to Truth Examined in the Light of Historical Considerations}

In attempting to trace the history of attitudes toward the search for the truth in the criminal process, I need not go so far back into the quicksands of history as to speculate on the possibly disparate role of the Norman idea of trial by battle played in England and on the Continent. Nor need I linger on the controversial problem whether the vacuum created by the papal prohibition of trials by ordeal was filled by more rational procedural devices in thirteenth century England or in thirteenth century Central and Western Europe. ${ }^{209}$ For my limited purposes it suffices to touch briefly on a less controversial historical development.

Because its verdict is not subject to attack, the English jury has possessed for at least three centuries the power to pardon the criminal $s u b$ rosa by acquitting him against the weight of evidence. This power, indeed, was used where jurors believed that the punishment was unduly severe, and at times even where the statute sought to be enforced was unpopular. ${ }^{210}$ This could not have failed to affect the perception of

207 This phrase is borrowed from Marx's essay on the parliamentary debate concerning the bill on larceny of firewood. See $1 \mathrm{~K}$. MARX \& F. ENGEIS, Sochinenia [Collected WORRs] 157 (2d ed., 1955). Although frequently used in the opposite sense, the phrase was in fact used in a context sympathetic to "formal barriers."

208 H. PACKER, supra note 171, at 170. See also Schwartz, Book Review, 120 U. PA. L. REv. 584, 596 (1972).

209 Some food for thought on this point can be found in $T$. PLJCENETr, A Concrse HISTORY OF THE COMIMON LAW 125 (5th ed. 1956). On the importance of this crossroad

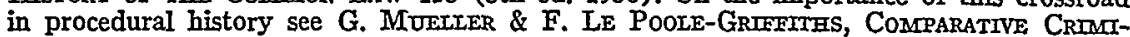
NAL Procedure 3-6 (1969).

210 L. Radzinowicz, A Erstory of English Crmunat Law 91-97 (1948), relates the role of the jury as a check on harsh and unpopular laws. The role of the jury in the struggle against political oppression is much less important than is commonly assumed. 
the aims of the criminal process. Gradually the idea evolved that criminal procedure may quite justifiably be used to frustrate as well as to enforce the substantive criminal law. In any event, the criminal trial ceased to be conceived solely as a vehicle to apply the substantive criminal law to concrete instances of its breach.

This curious phenomenon has no real counterpart in continental history of criminal procedure. ${ }^{211}$ It is true that continental substantive law was very harsh until the Age of the Enlightenment. The usual punishment (poena ordinaria) for the majority of serious offenses was the death penalty. As in England, this harshness seemed unduly severe to continental adjudicators. But, on the Continent, since there was no jury, alternative ways of coping with this problem were developed. Not a single one of them called for acquittals against the weight of evidence, with the complementary concept of frustrating the enforcement of the substantive criminal law. Perhaps the most important device of mitigation was the so-called extraordinary punishment (poena extraordinaria).$^{212}$ Where capital punishment was, strictly speaking, mandatory, but the judges felt that it was unduly severe in light of the circumstances of the case, they would, rather than acquitting the guilty defendant, simply disregard the sentencing provisions and impose a milder punishment. It is another irony of history that this practice, lambasted by the eighteenth century reformers as arbitrariness violating the defendant's rights, was in actual practice predominantly a mitigating device. Moreover, borrowing an idiom of modern

But there are some cases in which the jury has acquitted defendants in political cases, and these rare instances gain in significance when assessed against the background of continental political cases of the times. It is precisely because of the belief that the jury is a better guarantor of justice in political cases that jury trials-not very popular on the Continent-have been advocated elsewhere for political trials. For an example of attitudes in Tsarist Russia in favor of juries in political cases see S. KUCHERov, THE ORGANS OF SOVIET ADATINTSTRATION OF JUSTICE 339 (1970).

The power of the jury to acquit against the weight of the evidence seems clear at least since Bushell's Case, Vaughan 135, 6 Howell's State Trials 999, 124 Eng. Rep. 1006 (1670).

211 The closest parallels are the experiences with the transplanted jury trial in Tsarist Russia, see S. Kucherov, Courts, LaWYers, aND TRIALs UNDER THE LAST THREE TSARS 69-70 (1953), and in France, especially before the reform of 1941. See note 4 supra. It was, indeed, one of the most frequent criticisms of the jury trial that jurors tended to acquit against the weight of the evidence if they sympathized with the defendant. Even after the reforms, patterns of jury verdicts in France seemed to display traces of acquittals based on sympathy for the defendant. See G. STEFanI \& G. Levasseur, supra note 5 , at 470 . Thus, for example, women are more often acquitted than men (14\% as opposed to $4 \%$ in $1967,13 \%$ as opposed to $6 \%$ in 1968 , and $27 \%$ as opposed to $5 \%$ in 1969). For this information I am endebted to Mlle. Yvonne Marx, Centre Français de Droit Comparé, Paris.

212 A succinct history of poene extraordinaria with particular reference to its use as a mitigating device can be found in E. SCHMMOT, EINFÜRUNG IN DIE GESCHICHTE DER DEUTSCHEN STRAFRECHTSPFLEGE 166-69, 183-86 (3d ed. 1965). See also Sax, supra note 78, at 157. For other devices, such as directives from the monarch affecting specific cases, to mitigate the severity of criminal laws see 2 WAErberg, Gesalarelte kIEINERE SCHRIFTEN ÜBER STRAFrecht 138 (Vienna 1877). 
criminology, poena extraordinaria was frequently used to make the punishment fit the offender. ${ }^{213}$ There were, however, other factors operating against the acquittal of guilty defendants. The continental bench was bureaucratic and there were no laymen among the adjudicators. In such an institutional setting the idea of "sabotaging" unpopular laws could hardly have gained ground. Moreover, there was little sympathy for the plight of the defendant. The professional adjudicators were subjected to the usual process of case-hardening, and the boundaries of social class which existed between the defendant and his judges contributed to a lack of compassion. ${ }^{214}$

In sum, the idea that criminal proceedings could justifiably be used for purposes other than those of establishing the truth and enforcing the substantive criminal law is simply not part of the continental legal tradition. ${ }^{215}$ By contrast, it is an idée recue in the com-

213 Thus, extraordinary punishment would be imposed on minors, people with an unblemished record of prior behavior, and, quite frequently, in the presence of other strong mitigating circumstances. The ill-famed French medieval lettres de cachet, often used to crush political opposition, were also sometimes used as an instrument of mitigating harsh substantive criminal law which rigidly prescribed capital punishment. See Dession, Psychiatry and the Conditioning of Criminal Justice, 47 YaLE L.J. 319, 319-20 (1938).

$214 \mathrm{~A}$ good example is the use of torture as a legal means to obtain incriminating evidence. Those who experience difficulty in comprehending the cruelty of this "factfinding" device should examine, for a sense of the spirit of those times when moral sensitivities did not prevent a very lighthearted and unconcerned attitude toward the torture of defendants, the passages from Racine, Molière and Madame de Sevigné quoted in A. EsMeIN, supra note 10, at 348-49. But, and this seems to be often overlooked, certain categories of defendants were exempted from torture save in grave cases of what we would term today political offenses (crimina lesae maiestatis). If we look at the authorities we find, from the 13th until the first half of the 19th century, that these privileged defendants were almost exclusively noblemen or members of the social elite (e.g., doctors of law). See Las SIeTe ParTidas, Partida VII, titulo 30, ley 2, in 1 Codigos ANTIGUOS DE ESPAÑA (Alcubilla ed., Madrid 1885) (promulgated in 1265 by Alfonso $\mathrm{X}$ of Castile and Leon), translated, LAS SIETE PARTIDAS (published for the Comparative Law Bureau of The American Bar Association, 1931); B. Carpzov, supra note 78, Pars III, questio 118, nos. 65-76; I. Kassics, LaURea Virtutis SeU Tractatus de Praerogativis Nobimium Inclyti Regmi Hungariae 11, 61 (Pestini (Budapest) 1826). The reasons advanced for this privileged status were almost invariably related to the "dignitas rei," the defendant's dignity. See B. CARPzov, supra note 78, Pars III, questio 118, no. 65. Thus, humane feelings did exist, but were extended only to the dominant social group.

The relationship of the existence of torture within the framework of inquisitorial proceedings and commitment to truthfinding is often misunderstood. Many consider the use of torture as proof of lack of concern for reliability of factual findings. On the contrary, it may be said that torture resulted in fact from over-commitment to the discovery of truth. As I have attempted to demonstrate, the medieval system of legal proof was too demanding. Note 10 supra. The rejection of circumstantial evidence as sufficient proof of guilt made the use of coercion to extract a confession a practical necessity of the administration of criminal law in those days. See, e.g., P. F. MUYART de Vouglans, Institutes au Drort Crimrnel, Partie VI, 341 (Paris 1757); A. Esment, supra note 10 , at 276,282 . Commitment to truth discovery and success in attaining it should not be confused.

215 Consider the situation in continental jurisdictions following the abolition of torture in the 18 th century. Those who administered the criminal process feared that, as a result, the reliability of adjudication might be imperiled. They therefore continued to permit various types of pressure to testify, usually in the form of disciplinary punishment, e.g., for "obstinate lying," etc. See note 41 supra. Moreover, while conviction on 
mon law tradition. Perhaps the view of criminal procedure as much more than a device for the application of substantive law is stronger in America than it is elsewhere. ${ }^{216}$ In part a result of the peculiarities of legal development in the eighteenth and nineteenth centuries, this view is constantly revitalized in the American consciousness by the discrepancy between a number of criminal offenses and the values shared by substantial segments of the population.

\section{A Final Caveat}

A comparison of the history, the ideological preconceptions, and the procedural structure of the Anglo-American adversary system and the continental non-adversary system reveals that the latter exhibits a greater commitment to the pursuit of historic verity. A natural outgrowth of this disparity in the two systems' commitment to the pursuit of truth is a disparity in evidentiary barriers to conviction. The Anglo-American adversary system's commitment to values other than the pursuit of truth has caused it to erect higher evidentiary barriers than its continental non-adversary counterpart.

At this point, one question remains. Is the system which places a higher premium on the discovery of truth for that reason better equipped to achieve precision in its factual findings? $\mathrm{My}$ argument can easily be interpreted to imply an affirmative answer to this ques-

mere circumstantial evidence became legal in ordinary cases, only direct evidence (e.g., a confession or testimony of eyewitnesses) could support a conviction where capital punishment was threatened. This exception to the continental principle of "free evaluation of evidence" remained the law in some European countries until well into the 20th century. The heavy emphasis on untrammelled pursuit of the truth began to undergo a change at the time of the French revolution, when English criminal procedure was transferred to France. This transplantation signaled a period of general lessening of commitment to the discovery of truth in criminal cases on the Continent of Europe. But there are few instances of this lessening of commitment without accompanying "withdrawal symptoms." Both the rejection of the English procedure in France, and the almost universal dissatisfaction with the transplanted jury trial in the rest of continental Europe, can at least partially be explained along these lines.

216 It would be erroneous to assume that this perspective of the criminal process dates from pre-Revolutionary days. In early Massachusetts, for instance, there was little fear that criminal law enforcement posed a threat to civil liberties because of the courts' lack of power, which was attributable to the unquestioning acceptance of British precedent. Procedure was attuned to finding the truth. Concern about procedural safeguards became pronounced only later when government developed great interest in the outcome of cases and the courts, by deciding hitherto nonexistent challenges to the substance of the law, developed their power to affect the outcome of cases. Nelson, Emerging Notions of Modern Criminal Law in the Revolutionary Era: An Historical Perspective, 42 N.Y.U.L. REv. 450, 468-81 (1967).

The disparate emphasis placed on various purposes of the criminal process is reflected even in the context of legal education. If a continental law teacher is exposed to course offerings in criminal procedure in an American law school, his first reaction will be one of great bewilderment. "This is a course in adjective law only in a very minor way," he will probably say. "Rather than teach students how to apply substantive law to cases of its breach, American instructors concentrate to a great extent on problems leading to the frustration of the implementation mechanism, and problems of ascertaining guilt or innocence are overshadowed by other considerations." 
tion. As I am, thus, courting a serious danger of being misunderstood, a final word of caution is needed before I close.

While commitment to the discovery of truth in criminal cases and success in attaining it are related, they are obviously distinguishable. Motivation is surely important for the success of such an endeavor, but it is by no means a sufficient condition for it. As with all values, truth may be loved unwisely or too well. Thus, if the non-adversary system in its continental variant is indeed more committed to ascertain historic verity, this does not mean that its factual findings are ipso facto more reliable. ${ }^{217}$ Which of the two rival systems is better adapted to factfinding precision has been the subject of great dispute at least since the nineteenth century. ${ }^{218}$ In the heat of the debate the narrow issue of adversary versus non-adversary presentation of evidence has frequently been confused with the larger question of analyzing the cognitive potential of the two systems in toto. ${ }^{219}$ Until we learn much more from behavioral sciences, especially from psychology, this debate will not be put to rest. ${ }^{220}$ But-to avoid a final misunderstandingeven if one of the two systems is found to be better adapted to the discovery of the truth, this will not be decisive. In the dialectics of of the criminal process there is always a point where factinding precision must give way to other societal values. ${ }^{221}$

At times opinions will be voiced in both systems that one type of procedure is superior to the other both in terms of its fact-finding precision and in terms of its fairness. These views, often in panegyrical

217 An example from the past which presents the issue in cameo is the demanding standard of proof-sufficiency in medieval law, designed to decrease false convictions, which led to the use of torture in criminal proceedings, a practice which undoubtedly increased false convictions. See note 214 supra.

218 Many famous German lawyers of the 19th century thought that the presentation of evidence through direct and cross-examination was a psychologically preferable method of ascertaining the truth at trial. See note 38 supra; Jescheck, supra note 55 , at 239.

219 In addition to the presentation of evidence, the larger question embraces also the impact of stipulations, formal pleadings, preclusions, admissibility, rules of evidence, discovery, etc.

On the narrow issue of proof-taking by the judge as opposed to party-presentation of evidence, opinions are almost evenly divided. The superiority of partisan presentation of evidence is, of course, the predominant view in common law jurisdictions. See, e.g. Fuller, supra note 86, at 39-40. But cf. K. LLEWELIYN, supra note 157, at 447-48. With important modifications, adversary presentation of evidence is sometimes thought preferable even by continental lawyers. See Jescheck, supra note 55, at 250 . But the contrary view still prevails in the civil law system. See E. ScmMmT, supra note 128, at 201-02 (1970). See also R. SchIesinger, Comparative Law 344 (3d ed. 1970).

220 For examples of this empirical approach, probably more promising than speculations by lawyers, see Marshall, Marquis \& Oskamp. Effects of Kind of Questions and Atmosphere of Interrogation on Accuracy and Completeness of Testimony, 84 HARv. L. REv. 1620 (1971); Thibaut, Walker \& Loud, Adversary Presentation and Bias in Legal Decisionmaking, 86 HARv. L. REV. 386 (1972); Walker, Thibaut \& Andreoli, supra note 48. text.

221 On this difficult question see particularly notes $214,196-97$ supra \& accompanying 
form, must be examined with suspicion, for it often happens that what is gained on one front is lost on another. Thus, in the criminal process, concern for individual rights will often set limits to the pursuit of truth and conflict with the desire to establish the facts of the case. This potential "zero-sum" effect is denied mostly by those who claim that they have established an ideal social order. Actual failure to realize the ideal leads them to idealize the real. 